Radio and the Rise of the Nazis in Prewar Germany

\author{
Maja Adena \\ Ruben Enikolopov \\ Maria Petrova \\ Veronica Santarosa \\ Ekaterina Zhuravskaya
}

JEL Codes: J0, D0, H0, D74

Keywords: Propaganda, Dictatorship, Nazis, Radio, Media

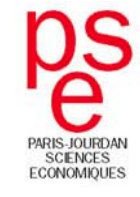




\title{
Radio and the Rise of the Nazis in Prewar Germany
}

\author{
Maja Adena, Ruben Enikolopov, Maria Petrova, Veronica Santarosa, and Ekaterina \\ Zhuravskaya*
}

August 23, 2013

How far can the media protect or undermine democratic institutions in unconsolidated democracies, and how persuasive can they be in ensuring public support for dictator's policies? We study this question in the context of Germany between 1929 and 1939. Using geographical and temporal variation in radio availability, we show that radio had a significant negative effect on the Nazi electoral support between 1929 and 1932, when political news were slanted against Nazi party. This effect was reversed in just 5 weeks following Hitler's appointment as chancellor and the transfer of control of the radio to the Nazis. Pro-Nazi radio propaganda caused higher vote for the Nazis in March 1933 election. After full consolidation of power, radio propaganda helped the Nazis to enroll new party members and encouraged denunciations of Jews and other open expressions of anti-Semitism. The effect of Nazi propaganda was not uniform. Depending on listeners' priors about the message, propaganda could be very effective or could backfire. Nazi radio was most effective in places where antiSemitism was historically high and had a negative effect on the support for anti-Semitic policies in places with historically low anti-Semitism.

\footnotetext{
* Maja Adena is from Wissenschaftszentrum Berlin für Sozialforschung. Ruben Enikolopov is from the Institute for Advanced Study and the New Economic School, Moscow. Maria Petrova is from Princeton University and the New Economic School. Veronica Santarosa is from the Law School of the University of Michigan. Ekaterina Zhuravskaya is from Paris School of Economics (EHESS) and the New Economic School. The research support of UniCredit and Universities (for Maria Petrova) is gratefully acknowledged. Ruben Enikolopov acknowledges support through Deutsche Bank membership during his stay at IAS. Corresponding author: Maria Petrova, mpetrova@nes.ru. We are grateful to Jürgen W. Falter, Nico Voigtländer, Hans-Joachim Voth, and the Bundesarchive for sharing their data. We thank Ben Olken for providing the software for ITM calculation. We also thank Anton Babkin, Michela Bunn, Natalia Chernova, Ivan Korolev, Gleb Romanyuk, and Denis Shishkin for their excellent research assistance. We thank Alberto Alesina, Bob Bates, Carles Boix, Filipe Campante, Ernesto Dal Bo, Stefano DellaVigna, Quoc-Anh Do, Raquel Fernandez, Jeffry Frieden, Matthew Gentzkow, Lisa George, Saumitra Jha, Alessandro Lizerri, Marc Meredith, Jesse Shapiro, Andrei Shleifer, B.K. Song, Nico Voighlaender, and audiences at Harvard University, Princeton University, Hunter College at CUNY, Sciences Po, NBER Political Economy Summer Institute, American Economic Association Meeting, and the 10th Workshop on Media Economics for useful comments.
} 


\section{Introduction}

Dictators often come to power through a democratic process. ${ }^{1}$ When this happens, which essential institutional elements of a consolidated democracy are missing? How do future dictators persuade voters to support them, and how do they maintain popularity during and after consolidation of power? What are the safeguards against the rise of popularity of potential dictators? We show that whether future dictators or pro-democratic forces have control over mass media in democracies and dictators maintain such control in dictatorships plays an important role in answering these questions. We also demonstrate that propaganda is most effective when people are already predisposed in favor of its message, but it can even be harmful for the dictator when listeners disagree with the content of the message.

The most prominent example of a collapse of democracy without a military coup was the rise of the Third Reich in Germany in the 1930s, which resulted in one of the largest catastrophes in the history of mankind. Did control over mass media help to establish and maintain Adolf Hitler's dictatorial rule? The Nazis themselves strongly believed in media power. The future Reich minister of propaganda, Joseph Goebbels, noted in his diary right after Hitler was appointed chancellor of Germany and one month before the last competitive election of Weimar Republic: "Now it will be easy to carry on the fight, for we can call on all the resources of the State. Radio and press are at our disposal. We shall stage a masterpiece of propaganda" (quoted in Shirer 1960). Later on, during the radio exhibition in Berlin in August 1933, he claimed, "It would not have been possible for us to take power or to use it in the ways we have without the radio..." Historians, however, have not reached consensus on this question. Some scholars provide case-study evidence in support of this view (e.g., Shirer 1960 and Somerville 2012). Others (e.g., Zimmermann 2006) suggest that propaganda was not nearly as effective as Goebbels had claimed. ${ }^{3}$ Prior to our paper, there was no systematic empirical analysis of the impact of radio on political support for Nazis during the collapse of

\footnotetext{
${ }^{1}$ Examples come from different parts of the world, e.g., Robert Mugabe of Zimbabwe, Alexander Lukashenko of Belarus, Hugo Chavez of Venezuela.

2 The full text of the speech in English can be found at http://www.calvin.edu/academic/cas/gpa/goeb56.htm.

3 For example, Zimmermann (2006) wrote, "However, Goebbels's insistent claims regarding the power of his own propaganda, together with the characteristic methods he used, have misled later generations of historians into believing, likewise, that the propaganda was effective, and into placing primary emphasis on the media as a system of persuasion - a misconception which persists today."
} 
the Weimar Republic and the rise of the Third Reich. More generally, there was no systematic empirical evidence of the role of media in anti-democratic transitions and consolidation of dictatorships. Our aim is to fill this gap by measuring the effect of mass media 1) on maintaining or undermining democratic institutions of an unconsolidated democracy, depending on which political forces have control over media, and 2) on assuring popular support for a dictator's policies after the full consolidation of dictatorial regime.

To identify the effect of radio we use a combination of a geographic variation in radio signal availability and of an over-time change in the content of radio broadcasts. In particular, we exploit the fact that during the Weimar Republic and the Third Reich the content of the broadcast changed twice, from having only educational and cultural programs before 1929 to having some political news with a mild anti-Nazi slant between 1929 and 1932 to heavy proNazi propaganda starting from 1933. To capture geographical variation in radio availability, we use engineering software (Irregular Terrain Model, Hufford, 2002, Olken, 2009) to predict the strength of radio signal at the time of each of these elections in every locality based on the information on the location and the power of radio transmitters. We show that our measure of radio signal is tightly related to actual radio listenership with and without controlling for a wide range of locality characteristics. The main determinant of the location of radio transmitters in each region was population density. We conduct a test in the spirit of AltonjiElder-Taber (2005) to verify that our estimates of the effect of radio signal in cross-section or panel specifications that rely on the variation in signal strength are unlikely to be biased due to the effect of unobservable confounds as they are not affected by the presence of a large set of observables. We show that, after controlling for urbanization (as measured by flexible polynomial of population and the city dummy) and province fixed effects, the part of the radio signal strength that can be predicted by the observables is not significantly associated with the outcomes of interest. Relying on the variation in the signal strength, however, is not crucial for our identification, as much of our analysis relies solely on the change in the content of radio broadcast holding the radio signal constant.

First, we examine how shifts in the content of radio broadcasts influenced political support for the Nazi Party, which was gaining popularity during this period. We can estimate these effects because the government of the Weimar Republic was unstable and, as a result, five parliamentary elections took place between 1928 and 1933, in addition to presidential 
elections of 1932. ${ }^{4}$ In response to the initiative of the German nationalists, including the Nazi Party (NSDAP) ${ }^{5}$, to organize referendum on renouncing the Treaty of Versailles in 1929, the Weimar government altered previously-apolitical mix of radio programming to include political news. These news broadcasts were slanted against the Nazis, as the Nazis (and the Communists) were never given airtime unlike other political parties, whereas analytical programs always took centrist, anti-extremist, and essentially, pro-government perspective. We show that in the first parliamentary elections after the radio became political, namely in September 1930, an increase in Nazi vote share was substantially lower in places with higher radio availability. The content of radio broadcast took another sharp turn - from having mild anti-Nazi slant to heavy pro-Nazi propaganda - after Hitler was named chancellor of Germany and gained complete control over radio, among other executive powers, in January 1933. Only 5 weeks later, in the last competitive parliamentary elections of the Weimar Republic in March 1933, the effect of radio was reversed, so that an increase in Nazi vote share was greater in places with higher radio availability. The results are robust to using contemporaneous radio signal strength or fixing it at any point in time between 1928 and 1933; this highlights the fact that the main driver of the reversal of the effect of the radio is, indeed, the change in radio content. We also verified robustness of our estimates to using matching estimator.

We then provide the results identified from changes in radio signal strength conditional on fixed characteristics of localities. The 1920s and 1930s was the time of rapid expansion of radio in Germany, and the number of radio subscriptions increased from essentially zero in 1924 to 2 million in 1928, to 3 million in 1930, and to more than 4.5 million in 1933. Thus, we can estimate the effect of radio diffusion, conditional on all time-invariant characteristics of localities, as well as time-specific shocks for all observable control variables. During the three elections between 1930 and 1932, when the radio content was biased against the Nazis, we find a significant negative effect of radio expansion on votes for the Nazi Party. In addition, in a specification allowing for differential effects of the radio over time, we show that radio availability had a significant negative effect on vote share of the Nazis in 1930, and significant

\footnotetext{
${ }^{4}$ These elections were held on May 1928, September 1930, July 1932, November 1932, and March 1933.

${ }^{5}$ NSDAP stands for Nationalsozialistische Deutsche Arbeiterpartei, the National Socialist German Workers' Party. It was founded in 1920 and dissolved in 1945.
} 
positive effect on the vote share of the Nazis in 1933. These results confirm that unobserved heterogeneity between localities is unlikely to drive our results.

Two counterfactual exercises highlight the role of the radio in the rise of the Third Reich. First, in the absence of the radio during the campaign for the September 1930 election, Nazis could have gained almost as many seats as their main competitor, the Social Democratic Party (SPD). Therefore, they could have had larger bargaining power over choosing the candidate for chancellor and ultimately could have gained executive power two-and-a-half years earlier. Second, in the absence of the shift in control over radio to the Nazis in January 1933, the subsequent elections would have produced a 1.2 percentage point lower vote share for the Nazi Party (which constitutes about 10 percent of what NSDAP actually gained between the November 1932 and March 1933 elections). The magnitude of this effect is modest, which is not entirely surprising, since the Nazi propaganda was in effect for only five weeks and was less dramatic compared to the other methods of achieving electoral win by the Nazis, which included the ban on the newspapers supporting the Centre Party, violent attacks on meetings of Social Democrats, the passage of Reichstag Fire Decree, which removed some basic civil right and allowed the arrest of all the leaders of the Communist party, etc. In addition, historical evidence suggests that in 1933 propaganda primarily targeted uneducated poor workers (Paul 1990 [1933]), who rarely had access to radio sets, as shown by our data. To better understand the magnitudes, we also calculate persuasion rates for both pro- and antiNazi messages, similar to DellaVigna and Kaplan (2007), DellaVigna et al. (forthcoming), DellaVigna and Gentzkow (2011), and Enikolopov et al. (2011). We find that in the last few months that Germany remained a democracy, the persuasion power of pro-Nazi propaganda was smaller than that of the anti-Nazi radio broadcasts for the previous three years.

In addition, we find that during both rounds of presidential elections in 1932, when radio had a pro-incumbent, anti-Nazi slant, radio signal a positive effect on the share of votes cast for the incumbent, Paul von Hindenburg. We also show that radio had a significant negative effect on the vote in the referendum against the Treaty of Versailles in 1929, which was supported by the Nazis. 
Our results confirm that radio propaganda was indeed an important tool in the struggle for power in the late Weimar Republic and was used both by the Nazis (after 1933) and by their opponents (before 1933).

The second question that we pursue in our analysis is whether radio helped the Nazis to maintain political support after they fully consolidated their power. We rely on such manifestations of political support for the regime as Nazi Party membership, deportations of Jews, and other expressions of anti-Semitism. ${ }^{6}$ We find that radio propaganda was important in persuading Germans to support the Nazi policies. First, radio availability increased the number of new members joining the Nazi Party after January 1933, when Nazis had full control over the content of radio broadcasts, but not in 1932, when they had no control over the content. The results imply that without radio propaganda, Nazi Party membership would have 13 percent lower in 1933. Radio exposure was also associated with higher levels of antiSemitism as measured by the number of anti-Jewish letters to Der Stürmer, one of leading Nazi newspapers, written by ordinary Germans between 1935-1938, and the number of Jews deported to concentration camps.

The effects of propaganda on the public expressions of anti-Semitism crucially depend on the listeners' predisposition to the broadcasted message. In particular, Nazi radio propaganda had a strong positive and significant effect on anti-Semitic expressions in places that historically were anti-Semitic, proxied by the occurrence of anti-Jewish pogroms during the Black Death in 1348-1350 (Voigtländer and Voth 2012). In contrast, in places where Jewish communities were present in 1349 , but the pogroms did not occur, i.e., where the local German population historically was not anti-Semitic, the effect of Nazi radio propaganda on public expression of anti-Semitism was negative. This result highlights potential pitfalls of propaganda, which can backfire if listeners are unlikely to believe it. This evidence also sheds light on the mechanism of the effect of the Nazi propaganda on the public expressions of antiSemitism. Potentially, it could serve as both persuasion and coordination devices, namely,

\footnotetext{
${ }^{6}$ Even though there were three parliamentary elections in the Nazi Germany-in November 1933, March 1936, and April 1938 - voting results from these elections are useless in measuring political support for Nazis during this time. As is typically the case in dictatorial regimes, the Nazis banned all opposition parties, and in all of these elections voters were presented with a single list containing only Nazi candidates. As a result, in 1933 the voter turnout and the vote for NSDAP were above $90 \%$, while in subsequent elections they were above $98 \%$.
} 
making people change their views as a result of propaganda or just signaling that certain actions will not be punished. As coordination mechanism is inconsistent with a negative effect of propaganda even if people are negatively predisposed to the message, one can conclude that at least a part of the effect is likely to come from direct persuasion, which could have both positive and negative effect depending on the prior attitude of listeners toward the broadcasted message.

A series of placebo tests provides evidence in favor of our identifying assumptions. We show that radio had no effect on outcomes that theoretically could not be affected by radio, namely, those measured before radio started to broadcast political news. In particular, future radio availability was not significantly associated with voting in Parliamentary elections in 1920, 1924 or 1928, with voting in Presidential elections in 1925, or with violence in 1920s.

Overall, the results suggest that, first, mass media can be both an important safeguard against the fall of unconsolidated democracy and an important facilitating factor in such a fall depending on who exercises control over content and whether the extremist speech is banned from the media and, second, mass media can help dictators gain popular support and persuade people in virtue of their most horrible policies.

Our paper relates to several growing literatures. First, the results contribute to our understanding of institutions in unconsolidated democracies and dictatorships (see Acemoglu and Robinson 2006 or Acemoglu and Robinson 2012 for an overview of the relevant literature). Our paper is the first to empirically assess the role of mass media in the process of institutional change, in particular, in the fall of a democracy and the rise of a dictatorship. ${ }^{7}$

Our paper also contributes to the literature on of the role of media in political persuasion. For instance, Strömberg (2004), DellaVigna and Kaplan (2007), Gentzkow (2006), Gerber, Karlan, Bergan (2009), Knight and Chiang (2009), Gentzkow et al. (2011), and Durante and Knight (2012) show that mass media can influence voting behavior in developed democracies. Enikolopov, Petrova, Zhuravskaya (2011) and DellaVigna et al. (forthcoming) document effects of media on voting behavior in immature democracies. Our paper differs from the previous studies of media effects on voting behavior in the following important

\footnotetext{
${ }^{7}$ Notable theoretical contributions to the theory of media in autocratic states are, for instance, Besley and Prat (2006), Egorov, Guriev, and Sonin (2009), and Gelbach and Sonin (2012).
} 
respects. First, while other papers look at the impact of media on political participation and vote choice within the setting of democratic institutions, our paper studies the role of media in two settings: 1) during the process of institutional change, namely, in protecting democracy from the collapse or facilitating this collapse and 2) within a dictatorship in fostering popular support of the dictator. Second, we study heterogeneity of the effect of propaganda and show that propaganda can be harmful for the dictator if the audience disagrees with its message. Our paper is the first one in the literature to show such negative effects of propaganda.

Our paper is also related to the literature on the effects of media on ethnic hatred and public expression of nationalistic feelings, i.e., DellaVigna et al. (forthcoming) and Yanagizawa (2012). In contrast to these contributions, our paper demonstrates the role of media for a much broader set of outcomes at the core of the process of anti-democratic transition as well as the role of media during the dictatorial regime for the public support of the dictator. In addition, we show that the effect of Nazi propaganda on ethnic violence depended on peoples' predispositions toward anti-Semitism. Particularly, audiences with negative predispositions towards anti-Semitism reacted negatively to the propaganda's message, while audiences with positive predispositions were most likely to be persuaded.

Finally, we contribute to the historical literature studying the determinants of electoral success of the Nazi party (Falter 1980, Ferguson and Voth 2008, King et al. 2006, Satyanath, Voigtländer and Voth 2013), the effects of propaganda in the Weimar Republic and Nazi Germany (e.g., Sington, Weidenfeld 1943; Ross 2006; and Zimmermann 2006), and the support of anti-Semitism when the Nazi were in power (Voigtländer and Voth 2012). Our paper, however, is the first to provide systematic, empirical evidence on the causal effect of radio propaganda on support for the Nazis.

The rest of the paper is organized as follows. Section 2 provides background information. Section 3 presents hypotheses. Section 4 describes data. Section 5 discusses empirical strategy and identification issues. Section 6 presents the empirical results. Section 7 concludes.

\section{Background}

\subsection{Political landscape}


The Weimar Republic was a parliamentary democracy established in Germany in 1919. Until 1932, its government was controlled by a coalition of centrist parties led by the democratically oriented Social Democratic Party of Germany (Sozialdemokratische Partei Deutschlands, SPD). Despite numerous economic problems, including hyperinflation in the first half of the 1920s, the coalition had a stable majority until 1930. However, the beginning of Great Depression, U.S. stock market crash of 1929, and associated recall of American short-term loans to Germany, together with continuous heavy burden of reparations, weakened the electoral support of parties in government. Early elections, held September 14, 1930, did not strengthen the coalition, but had the opposite result: the centrist parties lost a big share of the vote to opposition parties, and in 1930-1932 the centrist government could function only with the aid of presidential decrees. NSDAP certainly benefited from the economic crisis: it received $18.3 \%$ of the vote in 1930 , compared with just $2.6 \%$ in 1928 .

Ongoing economic depression led to further radicalization of the population. In the presidential election of March 1932, Adolf Hitler captured 30.1\% of votes in the first round, second only to the incumbent president, Paul von Hindenburg (49.6\%). In April 1932, Von Hindenburg won the second round over Hitler, $53 \%$ to $36.7 \%$ (there were three candidates in the race). In the early parliamentary elections held July 31, 1932, the Nazi Party received an astounding $37.3 \%$ of votes. The Nazis got electoral support from the growing ranks of the unemployed and financial support from rich industrialists who feared substantial tax increase to pay government debt. Despite strong electoral support of Hitler's party, von Hindenburg refused to appoint him chancellor. In the November 1932 parliamentary election, Nazis got lower vote share compared to previous elections, namely $33.1 \%$ of the vote. (In part, this was because the Nazi Party had some financial problems). However, as a result of misguided political strategizing during negotiations between von Hindenburg and ex-chancellor Franz von Papen (ironically, aimed at setting constraints on the Nazis), Hitler was appointed chancellor on January 30, 1933.

Shortly thereafter, the Nazis quickly set about consolidating all political power, including police and radio stations. Goebbels unleashed a widespread campaign of radio propaganda. After the allegedly staged Reichstag fire in February 1933, the Reichstag Fire Decree suspended most civil liberties and restricted the freedom of press. The Communist leaders were arrested. Terror began to spread over the country. A week later, in the last 
competitive pre-WWII elections in Germany, the NSDAP gained $43.9 \%$ of votes, which allowed the Nazis in coalition with the Centre Party to pass Enabling Act in 1933, which effectively allowed Hitler's government to enact decrees without consulting the Parliament. By the summer of 1933, all political parties except the NSDAP were outlawed, all independent newspapers were closed, Nazi officials were put in charge of all local governments, and trade unions were abolished and their leadership imprisoned. Germany had become a dictatorship.

\subsection{Radio content}

In 1923 and 1924, the state postal company (Reichspost) together with private investors created nine regional broadcasting companies in Germany. Initially, these companies controlled their own content. Their programming included music (concerts, stage plays, and operas), literary programs (belles lettres and poetry), weather, sports, scientific and popular lectures, and advertising. Local news was mostly limited to nonpolitical information about local affairs, such as retail prices and police calls for witnesses.

In their first year of operation, few regional companies experimented with broadcasting political news. However, within several months of operation, the news agency Dradag had centralized the production of all political news programs. During the parliamentary election campaigns in May 1924, when the number of radio subscribers reached 16,000, Dradag allocated 15 minutes of air time to each of the following five parties: Zentrum, the DNVP, the SPD, the DVP, and the DDP. ${ }^{8}$ In 1924, the Minister of Home Affairs, Karl Jarres, argued for the regulation of radio, recognizing the risk of abusive uncontrolled political influence on the masses (Dussel 2010). As a result, a majority stake in Dradag was nationalized and the editors were obliged to report in line with official government positions. During the campaigns leading up to the parliamentary election of December 1924, candidates were not given any airtime. By contrast, in the presidential election campaign of 1925, two candidates, von Hindenburg and Wilhelm Marx, were allocated radio time, whereas the Communist candidate, Ernst Thälmann, was not allowed to speak on the air. During this time, the role of politics in radio broadcasts was a subject of ongoing political debate. In 1926, a regulation forbidding

8 DNVP stands for Deutschnationale Volkspartei, the German National People's Party; SPD stands for Sozialdemokratische Partei Deutschlands, the Social Democratic Party of Germany; DVP - Deutsche Volkspartei, the German People's Party; DDP - Deutsche Demokratische Partei, the German Democratic Party. 
any political, especially partisan, content was enacted. Between 1926 and 1928, radio was deliberately apolitical; broadcasts consisted of cultural and entertainment programs. During the parliamentary elections of 1928 , no content related to electoral campaigns was aired.

However, in 1929, the policy regarding radio content changed. The Nazi Party, in coalition with other right-wing parties, organized a referendum against respecting reparations required under the Treaty of Versailles (i.e., the so-called Young Plan). In response, the government launched an intensive campaign to encourage voting "no" in the referendum (Bausch 1956, p. 124). ${ }^{9}$ After 1929, radio became increasingly politicized, offering more and more pro-government and pro-democratic content, which included economic and political news, lectures, and speeches. During the parliamentary election campaigns in 1930 and July 1932, airtime was given to all major parties with the exception of the Nazis (NSDAP) and the Communists (KPD). During the presidential election campaigns in the spring of 1932, airtime was given exclusively to the incumbent president, von Hindenburg. During the campaigns for the parliamentary election of November 1932, the Nazi Party was given some airtime. The government, however, reserved a disproportionate amount of broadcasting time for itself (Pohle 1955).

After the elections of July 1932, the regional broadcasting companies were reformed, becoming more centralized and nationalized. Under Chancellor von Papen, radio was brought under firm state control over the latter half of 1932. "As part of this restructuring, Interior Minister von Gayl ordered a daily 'Government Hour' for all radio broadcasters, during which ministers could hold supposedly 'unpolitical' speeches in support of government policies," (Ross 2006). By November 1932, the centralization and nationalization of all radio broadcasts was completed.

Before Hitler was appointed chancellor, on January 30, 1933, the Nazis had virtually no influence on the content of radio broadcasts and radio content had been slanted against the Nazi Party (Ross 2006). But under Hitler, radio programming changed sharply, and swiftly. Between February 1 and the parliamentary elections of March 5, the Nazis launched an intensive daily radio advertising campaign. The Nazis also minimized airtime for its coalition

\footnotetext{
${ }^{9}$ The referendum failed due to insufficient turnout.
} 
partner, the DNVP, and blocked access for all other parties (Diller 1980, p. 61). Radio content became dominated by propaganda aimed primarily at uneducated workers (Paul 1990 [1933], p. 39). The broadcasts from demonstrations, marches, and rallies were to transmit the illusion that the Nazi movement was massively popular, which in turn would garner more votes during the upcoming elections. In 1934, Goebbels claimed that radio played a significant role in winning "the war of propaganda" and allowed Nazis to win the March 1933 elections (Weiss 1932, p. 9). The Nazis would continue to use radio as one of their main propaganda tools up until their defeat.

Figure 1 portrays the timeline of the key political events and of the measurement of all variables used as outcomes in this paper.

\subsection{Availability of radio}

At the end of 1920s and the beginning of the 1930s, the German radio network rapidly expanded. In September 1930, there was just one big transmitter (over 10kW of power); by April 1932, there were three, and by March 1933, there were six (Lerg 1980). In 1927, the transmitters' signal reached just $31.3 \%$ of the German population; construction of big transmitters from 1930 to 1934 extended that reach to $70 \%$ of the population. Radio listenership, measured by subscription rates, was expanding fast, from essentially zero in 1924 to almost 5 million by the end of 1933 (see Figure 2). Each year thereafter saw about 1 million additional radio listeners (Vaessen 1938). ${ }^{10}$

Initially, the country was divided into in nine broadcasting districts, each with a diameter of about $200-300 \mathrm{~km}$. To make the signal available to as many people as possible, one transmitter was built in the center of the major city of each broadcasting district. Each transmitter was operated by the corresponding regional broadcasting company. The range and quality of the signal was insufficient to provide uniform radio signal coverage over the country. The twin demands for more localized content from areas with the signal and for radio availability from areas with no signal led to the construction of additional transmitters. The Geneva Frequency Plan, which came into effect in November 1926, reduced the number of available radio frequencies and led to the creation of single-frequency networks in each of the

\footnotetext{
${ }^{10}$ These figures are a lower bound on the number of radio listeners, because they do not take into account that there were several listeners per subscription. Nor do they account for those who evaded the subscription fee.
} 
nine broadcasting districts. This resulted in uniform programs within each of the broadcasting districts despite the demand for more local content. The technical upgrades of more powerful transmitters required moving them from the city center to the outskirts (Schütte 1971). A study of population densities was conducted to determine the optimal location for big transmitters. ${ }^{11}$ An important rationale for upgrading the power of existing transmitters and building new ones was to reduce signal disturbances from foreign transmitters near the border. ${ }^{12}$

Radio listenership was significantly higher in the big cities with transmitters and suburban area around them, as the signal was sufficiently strong for reception with a relatively cheap crystal radio receiver. Listenership was lower in rural areas, however, because fewer citizens had the more powerful radio sets needed to capture broadcasts. Technical progress led to improvement of radio receivers over time; however, their quality and price varied substantially. The cheapest crystal radio receiver was available for 25 to 30 marks, while more sophisticated vacuum detectors ranged from 110 to 380 marks. Anecdotal evidence shows that a growing number of German houses in the 1920s and 1930s were equipped with homemade radios. During the First World War, 4,000 radio operators were trained to assemble their own receivers, and members of many local radio clubs also made their own receivers. Overall, radio listenership was higher in places with higher population density, better economic conditions, and more favorable terrain (Cebulla 2004, p. 34). Radio listenership was further hindered in rural areas by the widespread lack of electricity; at the time, $96.5 \%$ of receivers required power supply. ${ }^{13}$ In addition, there was a monthly radio license fee of 2 marks, roughly equivalent to the price of a monthly newspaper subscription, two hours of skilled labor, or four hours of unskilled labor.

From 1933 onward, the Nazis strived to increase the number of radio listeners. An affordable radio receiver, the Volksempfänger (people's receiver), was presented August 18, 1933, during the international radio exhibition in Berlin; Goebbels ordered to produce it.

\footnotetext{
${ }^{11}$ Neuordnung des Rundfunks in Deutschland. Der Deutsche Rundfunk, Nr. 49, 6.12.1929, p. 1545f.

${ }^{12}$ For example, the transmitter in Flensburg was constructed in December 1928 as a response to a nearby Danish transmitter. The transmitter in Gleiwitz was built in 1925 because of a Polish transmitter in nearby Kattowitz, and its power was increased to $12 \mathrm{~kW}$ in 1927 after the power of the Kattowitz transmitter was increased to $10 \mathrm{~kW}$. This upgrade made the "supplementary" transmitter in Gleiwitz the third most powerful in Germany at that time (Schütte 1971).

${ }^{13}$ Numbers for July 1933 and July 1934 from Vollmann (1936).
} 
Radio was also made available to those who could not afford a private radio receiver: "The party through its 'wireless wardens' and 'block wardens' in every village and town, help[s] to install communal receiving sets, organizes group listening, lays down rules about the erection of aerials, and reports on illegal listening-in to foreign stations" (Sington and Weidenfeld 1943).

\section{Hypotheses}

First, to test whether the radio played a role in dismantling the democratic institutions of the late Weimar Republic, we consider how radio availability affected voting for the Nazi Party during three periods: (1) before 1929, when radio was neutral and apolitical; (2) between 1929 and 1932, when radio had a relatively mild pro-government, pro-democracy and anti-Nazi slant; and (3) after January 1933, when the Nazis used radio as a full-fledged propaganda machine. We expect that exposure to radio decreased the vote share of the Nazi Party at the time when radio had an anti-Nazi slant and increased the vote share of the Nazi Party after it got control over the radio. An important falsification test is to verify that radio signal was uncorrelated with the Nazi vote share conditional on observables before radio got political content.

Second, we investigate the effect of radio on the support for Nazi policies after Hitler established dictatorial rule in 1933. We expect radio propaganda to increase the number of new members in the Nazi Party and promote open expressions of anti-Semitic sentiment among ordinary Germans.

Third, we test the hypothesis about the difference in persuasion power of the propaganda messages between audiences more and less positively predisposed to the content of the message. We expect that in places with higher initial levels of anti-Semitism, Nazi radio propaganda had a larger effect on the expressions of anti-Semitic sentiments compared to places with lower initial levels of anti-Semitism.

Fourth, radio was far from being the only means of political persuasion. Even before taking control over radio, Nazis organized fierce political campaigns using posters, street rallies, and door-to-door campaigning. We test whether radio propaganda was a substitute or complement to one of the other tools of Nazi political persuasion: Hitler's electoral speeches. 


\section{Data}

Radio availability. We calculate radio availability using information on the radio transmitters. Our primary source of data for transmitter location, frequency, and power is Mitteilungen der Reichs-Rundfunk-Gesellschaft (various years). In addition, we use data from Rundfunk Jahrbuch 1929 for the year 1928. All these sources refer to Union Internationale de Télécommunications as the primary source of their data. Based on this information, we calculate predicted radio signal strength in all localities using the Irregular Terrain Model (Hufford 2002, employed also by Olken 2008, Enikolopov et al. 2011, and DellaVigna et al. forthcoming). For each district (Kreis) and each town, we compute signal strength at their geographical centers. The district boundaries come from the map of administrative borders in 1925. Figure A1 in online appendix presents the map of the radio signal strength and Figure 3 shows the spatial variation in signal strength conditional on urbanization and province fixed effects at these points in time.

Electoral measures. The data on elections come from Falter and Hänisch (1990) and ICPSR (1999). We use voting results for the five parliamentary (Reichstag) elections between 1928 and 1933, two rounds of presidential elections in March and April 1932, and the referendum on the "Law Against the Enslavement of German People" in December 1929. For the parliamentary elections, we focus mainly on the Nazi vote share, but we also consider the vote shares of other major parties and voter turnout. For the presidential elections, the outcomes are the shares of votes received by the main candidates: Hitler, von Hindenburg, and Thälmann. We use two referendum outcomes: (1) the number of signatures collected in favor of submitting the law proposal to the parliament as a share of the total number of registered voters, and (2) the number of votes in favor of the proposal during the referendum as a share of registered voters. ${ }^{14}$

\footnotetext{
${ }^{14}$ According to the German constitution of that time, if at least ten percent of eligible voters registered their approval of a law proposal, it was sent to the Reichstag for consideration. If the Reichstag rejected this proposal, it was voted on in a referendum. For a proposed law that did not require changes in the constitution to pass referendum, a majority of eligible voters had to turn up to the polls and a majority of those who turned up had to vote in favor of the proposal. Voter turnout at the referendum was extremely low (about 12 percent), so not voting was equivalent to casting the vote against the law. This is why we use the share of those who voted in favor of the law in the total number of eligible (registered) voters rather than as a share of valid votes.
} 
Anti-Semitism measures. The measures of anti-Semitism primarily come from Voigtländer and Voth (2012). In particular, we use the information on the number of anti-Semitic letters to Der Stürmer from 1935 to 1938, a dummy variable for whether synagogues or Jewish prayer rooms were damaged or destroyed during the Reichskristallnacht in 1938, and the information on the number of Jews deported from 1933 to 1942. After 1942, deportations of Jews grew into a systematic and massive policy and, therefore, stopped being a proxy for local antiSemitism. Before 1942, however, deportations reflected hostility of local officials and nonJewish neighbors. For example, Gellately (2001) provides evidence that the vast majority of the Gestapo cases against the Jews were based on denunciations by local non-Jewish population. This variable comes from the database of Jewish deportees during the Nazi period, which was compiled by the German Federal Archives (Bundesarchiv 2007).

NSDAP membership. The information on NSDAP membership comes from the data set of party membership cards (Brustein and Falter, 1995). Based on these data, we compute the number of people who joined NSDAP in 1932 and 1933, by city. We restrict the sample to those cities for which there is at least one observation in both 1932 and 1933. The reason for this is that missing data for a particular city-year does not mean that there were no new members from this city joining NSDAP, as the data are a random sample of party membership cards stratified at the city and year level.

Control variables. For sociodemographic variables, our primary source was data from Zentralarchiv and German census data from Falter and Hänisch (1990). In particular, we use the following sociodemographic controls from the census data: the share of Jewish and Catholic population, and the share of workers in white- and blue-collar occupations in 1925; the shares of unemployed and partially employed people in 1933. We control for unemployment, as it was an important determinant of pro-Nazi voting (Childers 1983 and King et al. 2008). However, measures of unemployment are available only from the period after most of the considered elections took place. To make sure that potential reverse causality from election results to employment levels does not affect our results, we report regressions with and without 1933 unemployment controls throughout the paper.

We also use data on property tax payments and the number of participants of World War I, welfare recipients, and pensioners receiving social assistance from the statistical 
yearbooks (Statistik des Deutschen Reichs for various years; see appendix for details). We also construct a variable on the number of speeches that Hitler gave in 1932 in each city based on the information from Domarus (1962). As historical anti-Semitism is an important determinant of pro-Nazi voting and anti-Semitic violence (see Voigtländer and Voth 2012), we include measures of the incidence of pogroms and information on the existence of Jewish settlement in the 14th century from Voigtländer and Voth (2012).

Most of the variables are measured at the district level using the administrative borders in 1925. The district units in election data and sociodemographic data were manually merged to district units in $1925 .{ }^{15}$ The number of districts in the dataset is between 918 and 959 , depending on the year. In contrast, the data on anti-Semitism from Voigtländer and and Voth (2012) and the data on NSDAP membership are at the town level. All data sources are described in more detail in the appendix, and the summary statistics for all variables is presented in Table A1 in the appendix.

\section{Empirical framework}

In this section, we present our main specification and motivate it with a series of reality checks and evidence in favor of the identifying assumptions.

\subsection{Specification}

First, we examine the effect of radio exposure on the rise of electoral support for the Nazis using the following specification, which we estimate separately for each of the elections of September 1930, July 1932, November 1932, and March 1933:

$$
\Delta y_{i t}=\beta_{0 t}+\beta_{1 t} \text { Radio_exposure } e_{i t}+\boldsymbol{X}_{i t}{ }^{\prime} \boldsymbol{\beta}_{2}+\phi_{p t}+\epsilon_{i t},
$$

where $i$ indexes districts and $t$ indexes elections; $\Delta y_{i t}$ is the change in vote share for the Nazi Party in district $i$ between elections in period $t$ and the previous elections in period $t-1$; radio_exposure $_{i t}$ is a measure of exposure to radio, and $\phi_{p t}$ is a province fixed effect that

\footnotetext{
${ }^{15}$ In cases when the level of election and socioeconomic data did not coincide with 1925 administrative districts (Kreis), we merged units in Census and elections data from Falter and Hänisch (1990) dataset with 1925 units using maps. Note that the number of electoral districts is different in different years; this is due to gerrymandering.
} 
takes into account variation between provinces, and therefore, we focus on within-province variation. ${ }^{16} \epsilon_{i t}$ describes unobserved heterogeneity.

$\boldsymbol{X}_{\boldsymbol{i}}$ is the following set of controls. As both radio signal strength and voting for Nazis were strongly correlated with urbanization, it is important to control flexibly for population. In particular, we control for the fifth-degree polynomial of population and a dummy for city status of the district. As a measure of preexisting political preferences, we control for vote shares of the two nationalistic parties (DNVP and NSFB), the two main non-nationalistic parties, (SPD and Zentrum) and voter turnout in 1924, the year when radio was not yet available to the general public. We also control for the shares of Jewish and Catholic population in 1925, the shares of blue- and white-collar workers, average property-tax payments, and the population shares of World War I veterans, welfare recipients, and pensioners receiving social assistance. In addition, we control for the historical measure of anti-Semitism, i.e., pogroms in 1349, and the existence of Jewish settlement that year. For each specification, we present the results with and without the measures of unemployment in 1933 (shares of the unemployed and partially employed) as additional covariates.

We also run a set of panel specifications with district and time fixed effects to account for time-invariant unobserved characteristics of the localities. In the first panel specification we estimate the regression for the three consecutive elections in 1930 to 1932 when the radio was anti-Nazi:

$$
y_{i t}=\beta_{0}+\beta_{1} \text { Radio_exposure } e_{i t}+\boldsymbol{Z}_{i t}{ }^{\prime} \boldsymbol{\beta}_{2}+\varphi_{i}+\tau_{t}+\epsilon_{i t},
$$

where $y_{i t}$ stands for the level of the vote share for the Nazi Party in district $i$ and election $t . \varphi_{i}$ stands for the district fixed effects and $\tau_{t}$ is fixed effect for each period, i.e., each election $t$. In all panel specifications, we interact all time-invariant controls with time effects, and $\boldsymbol{Z}_{\boldsymbol{i t}}$ stands for the set of these interactions.

The next panel specification uses data on all time periods and estimates the effect of radio exposure for each year separately:

$$
y_{i t}=\beta_{0}+\sum_{j \in(1928 ; 1933)} \beta_{1 j} * I_{t=j} * \text { Radio_exposure } e_{i t}+\boldsymbol{Z}_{i t}{ }^{\prime} \boldsymbol{\beta}_{2}+\varphi_{i}+\tau_{t}+\epsilon_{i t},
$$

\footnotetext{
${ }^{16}$ Previous literature on voting for the Nazi Party focused mostly on regional differences.
} 
where $I$ is an indicator variable for each of the five elections between 1928 and 1933.

Finally, we take into account changes in the radio content directly and estimate the following panel regression:

$$
y_{i t}=\beta_{0}+\beta_{1} \text { Nazi_bias }_{t} * \text { Radio_exposure }_{i t}+\boldsymbol{Z}_{i t}{ }^{\prime} \boldsymbol{\beta}_{\mathbf{2}}+\varphi_{i}+\tau_{t}+\epsilon_{i t} \text {, }
$$

where Nazi_bias $_{t}$ is an indicator of the radio bias in favor of Nazis at time $t$, which takes value zero if there was no bias, -1 if the bias was anti-Nazi, and 1 if the bias was pro-Nazi.

We also estimate the effect of radio exposure on the cross-sectional outcomes $k_{i t}$, such as the results of the referendum in 1929, the presidential election in 1932:

$$
k_{i p t}=\beta_{0}+\beta_{1 t} \text { Radio_exposure } \text { ipt }+\boldsymbol{X}_{\text {ipt }}{ }^{\prime} \boldsymbol{\beta}_{2}+\phi_{p}+\epsilon_{\text {ipt }} \text {. }
$$

The effects of Nazi propaganda on the membership of the Nazi Party and the expressions of anti-Semitism are estimated using specifications, similar to (5), but on a sample of cities, rather than the population of districts, as described below.

\subsection{Signal strength and listenership}

Since our hypotheses link the outcomes to radio exposure, it is important to verify that the signal strength, which we use as the main explanatory variable, is a good proxy for the actual radio listenership. Because owners of radio sets had to pay a monthly subscription fee to listen to the radio, we can use information on the number of subscriptions in each region at different points of time to proxy for listenership. ${ }^{17}$ Table 1 presents the relationship between radio subscriptions and signal strength for the years 1930 to 1933. Each cross-sectional regression includes the standard set of controls (columns 1 to 4). Column 5 presents results of a panel regression with district and time fixed effects. In all instances, the coefficient on the predicted signal strength is positive and highly significant. A one-standard-deviation increase in the signal strength was associated with a 3.1-percentage-point increase in the share of population with a radio subscription in 1930 (with the mean of 18.8 percent of subscribers in total district population as of 1931). In 1933, a one-standard-deviation increase in the signal strength was

\footnotetext{
${ }^{17}$ The number of subscribers should be proportional to actual listenership but is substantially smaller, as it does not take into account that, on average, several people listen to one radio set with a subscription and that some people listened to radio without paying the subscription fee.
} 
associated with 1.9 additional percentage points in the share of subscribers (with the mean value of 26 percent).

Figures $4 \mathrm{~A}$ and $4 \mathrm{~B}$ present the results of a nonparametric estimation of this relationship with and without controls. The plots show that an increase in the signal strength translated into additional subscriptions only after a certain threshold level of signal strength. This is reasonable, as below this threshold, the quality of the signal was insufficient to listen to the radio (similar-shape relationships have been documented in other contexts, e.g., Olken 2009). ${ }^{18}$ Overall, we find a very strong positive relationship between the quality of radio signal in the Weimar Republic and radio listenership.

\subsection{Identification assumptions and determinants of radio availability}

Our identification assumption in specifications that rely on the variation in radio signal is that, conditional on observable differences between locations, the variation in the predicted signal strength was not correlated with the unobserved characteristics affecting the change in political support for the Nazis in regressions for the first differences, e.g., equation (1) and (2), and the level of political support for the Nazis in regressions for the levels, e.g., equation (5). In contrast, in specifications that rely on the change in the content of the radio broadcasts over time, such as equations (3) and (4), we can relax this assumption and identify the effect of radio propaganda under a much weaker assumption that the effect of unobservables is similar before and after the change in the pro-Nazi bias in radio coverage.

Here, we provide information on the determinants of signal strength and provide arguments in favor of the validity of our identifying assumptions. The signal strength in each location depends on the distance to transmitters, their power, and topography in the line of sight between transmitters and the location. Because transmitters are not randomly located, signal strength correlates with socioeconomic characteristics of locations. ${ }^{19}$ Table $2 \mathrm{~A}$ presents the results of cross-sectional regressions, in which the predicted signal strength is related to the set of our control variables. Fifty to sixty percent of variation in the signal strength is

\footnotetext{
${ }^{18}$ The threshold level depends on the quality of receivers, which changes with technological progress. Thus, the level of the threshold cannot be compared across different contexts.

${ }^{19}$ The variation in signal strength coming from topography conditional on free-space signal is insufficient for much of the German territory, and therefore, we rely on the variation in signal strength coming both from topography and distance to transmitters.
} 
explained by socioeconomic and demographic characteristics of the districts. The most important explanatory variables are the fifth-order polynomial of population (with F-statistic of joint significance of its terms varying from 7 to 10) and the city status of the district (significant at the 1 percent level), which is consistent with the historical fact that population density was the main determinant of the location of transmitters. However, some socioeconomic and political characteristics, and in particular, the share of white white-collar workers, the voter turnout in 1924 and the vote for NSFB party in 1924, are significant correlates of radio signal strength across districts between 1928 and 1933, even conditional on urbanization as the main determinant of transmitter location.

The fact that signal strength is significantly correlated with voting outcomes before the appearance of radio is a potential concern, since this may indicate that some unobservable characteristics of districts determining our outcomes of interest are correlated with signal strength, which would bias the results that rely on the variation in the radio signal. The presence of correlation between unobservables and our main explanatory variable is untestable. However, we perform a series of tests in the spirit of Altonji, Elder, and Taber (2005) to show that such a correlation is not likely to bias the results, under a reasonable assumption that unobservables are correlated with observables. In particular, we first predict signal strength in each district with its socioeconomic characteristics and voting outcomes as of 1924 by taking the fitted value from the regressions of signal strength on the full set of controls from Table 2A, with the exception of the most fundamental structural determinants of the support for the Nazis for which we control directly throughout, namely, the polynomial of population, province fixed effects, and city dummy. After that, we relate this fitted value to the outcomes of interest controlling for the fundamental determinants of Nazi support. Table 2B presents the results of the second stage of this exercise. It indicates whether observables that are correlated with radio availability (aggregated into the fitted value for the signal strength) are associated with the outcomes of interest. We find no correlation for any of the outcomes in cross-section or panel specifications. This test suggests that the results based on specifications that rely on the variation in the radio signal are unlikely to be driven by the unobserved heterogeneity across localities or over time. Importantly, below, we also report results for specifications that rely only on the change in radio content from anti-Nazi to pro-Nazi holding radio signal constant. These results do not require the absence of unobservables affecting both 
signal strength and outcome variables. In addition, below we report results of a series of placebo tests, the results of which also confirm the validity of our identification.

\section{Results.}

\subsection{The effect of radio on support for the Nazis while Germany was still a democracy}

Table 3 presents results of cross-sectional regressions in which the change in the Nazi vote share from the previous election is related to the signal strength of German radio for each parliamentary election between September 1930 and March 1933. Specifically, Panel A presents estimation results of equation (1) with the signal strength as a proxy for radio exposure. We report results with and without unemployment controls. The list of baseline covariates is described in section 5 .

The results show that radio availability had drastically different effects on political support for the Nazi Party at different points in time depending on its content. There is a negative and significant effect of radio on the change in Nazi vote share between elections of 1928 and 1930, as radio content shifted from neutral to anti-Nazi. The magnitude of the effect implies that a one standard deviation increase in the signal strength led to a 0.7 percentage point smaller increase in the share of votes for NSDAP between 1928 and 1930. There is no effect of radio availability on the gain of votes by the Nazis from the previous election for two consecutive elections in 1932, when radio content was not changing. And there is a positive and significant effect of the signal strength on the gain of votes by the Nazis between elections in November 1932 and March 1933, when content became heavily pro-Nazi. The magnitude of the effect implies that a one standard deviation increase in the signal strength led to a 0.5 percentage point larger increase in the share of votes for NSDAP between November 1932 and March 1933. The scatterplots for these regressions indicate that none of the results are driven by outliers (see Figure A2 in the appendix) and reflects a shift in the distribution of votes (see Figure A3 in the appendix).

To make sure that the differences in the estimated effects of radio content across the three time periods - namely, before content became political, when it became anti-Nazi, and when it turned pro-Nazi - are driven by the differences in content rather than in the over-time changes of radio signal, we re-estimate equation (1) using leads and lags of the signal strength measure. Figure 5 reports the results. We plot point estimates of coefficients on the lags and 
leads of signal strength along with their confidence intervals for equation. It is apparent from the figure that the differences in results between the three time periods are, indeed, driven by the differences in broadcast content.

To get a better sense of the magnitude of the effect, we also consider our proxy for listenership - the share of the district population with subscription to the radio-as a measure of radio exposure. We instrument the radio subscription rate with signal strength because it is a choice variable for individuals and, therefore, is endogenous, as individuals can self-select into listening to radio depending on their political preferences. Panel B of Table 3 presents the results of these IV regressions. According to IV results, a one standard deviation increase in subscription rate in a district led to a decrease in Nazi vote share by 2.3 percentage points in 1930 and an increase in Nazi vote share by 1.7 percentage points in 1933, in comparison to their results in previous elections. For comparison, we also report OLS results for the subscription rate, which are smaller in magnitude, possibly, because of a measurement error in listenership variable.

Table A2 in the appendix illustrates how the point estimate of the coefficient on the signal strength is affected by changes in the list of covariates. We present results for the elections of September 1930 and March 1933. First, the unconditional bivariate relationship is presented and then covariates are added progressively. For the elections of September 1930, the magnitude of the coefficient on radio signal strength decreases somewhat after the inclusion of regional fixed effects; but after that, it is almost completely unaffected by changes in the set of controls. It is equal to -0.106 in bivariate relationship, goes down to -0.067 when province fixed effects are included as controls, and -0.051 when the full set of controls is added. Note that R-squared increases from 0.03 in a bivariate specification to 0.43 after the addition of regional fixed effects, and to 0.65 in the baseline specification with full set of controls. The fact that the point estimate does not change much despite such a dramatic increase in explanatory power suggests that it is unlikely that correlation with unobservables substantially biases our estimates. For the elections of 1933, the coefficient is small and statistically insignificant in the bivariate regression. The magnitude of the coefficient increases from 0.015 to 0.042 and it becomes statistically significant at $10 \%$ level after the addition of regional fixed effects and measures of urbanization, which are the most important determinants of the location of transmitters and directly affect the support for the Nazis. After 
that, additional controls have almost no effect on the magnitude of the coefficient, while Rsquared increases from 0.60 to 0.70 . Thus, the results based on within-province variation across localities of similar size in 1933 appear to be robust. Therefore, as long as unobservables are uncorrelated with urbanization (for which we control throughout), they are unlikely to bias the results for 1933. Appendix table A3 verifies that the results are robust to using matching estimator instead of OLS. ${ }^{20}$

During the 1930s, radio was expanding and, therefore, we can also explore the overtime changes in the signal strength to estimate the persuasion power of the radio, controlling for time-invariant unobserved heterogeneity between districts with district fixed effects. At first, we confine our analysis to the three consecutive elections in which radio was anti-Nazi, in 1930 to 1932 (i.e., we estimate equation (2)). Columns 1 and 2 of Table 4 present the results of estimation of this panel specification. We find that the 1930-1932 expansion of radio led to a significantly smaller Nazi vote share in districts that gained access to the radio during this time, conditional on all observables as well as unobserved heterogeneity between districts. The magnitude of the point estimates is approximately 20 percent smaller than that without district fixed effects for 1930 (reported in columns 1-2 of Table 2).

Columns 3 and 4 of Table 4 present panel estimation for the full set of elections (19281933), in which signal strength is interacted with time dummies, which corresponds to equation (3). Consistent with the cross-sectional estimates, we find a negative and significant effect of radio availability on the Nazi vote share in 1930 and a positive and significant effect of radio on voting the Nazi vote share in 1933. Interestingly, with district fixed effects, the magnitude of the effect in 1930 is smaller than in 1933. In columns 5 and 6 of the table, we report estimation of equation (4) with radio availability interacted with the measure of proNazi bias equal to 0 in 1928, -1 in 1930-1932, and 1 in 1933. This specification combines the effects of the change in the radio content with the change in the radio availability due to radio expansion. We find that radio availability interacted with the pro-Nazi bias variable has a positive and significant effect on the Nazi vote.

\footnotetext{
${ }^{20}$ To do the matching, we use alternative thresholds for signal strength, to create mapping between a continuous signal strength measure and binary signal variable for matching estimator, based on the relationship between listenership and signal strength. We use nearest neighbor matching for all the controls that we include in our regressions, with exact matching by province, city status, and the extent of historical anti-Semitism.
} 
These panel-data specifications confirm that time-invariant unobserved heterogeneity is not what drives our results in cross-section specifications with the change in Nazi vote share as dependent variable. The results remain strong and significant when we include location and time fixed effects as well as flexible controls for the observables, irrespective of whether we identify an effect from variation in radio content or from radio expansion. ${ }^{21}$

The effects of the radio presented above are not confined to voting for the Nazi Party in parliamentary elections. To show this, we first, estimate equation (5) for the effect of radio availability on political support for the Nazi-initiated referendum for the "Law against the Enslavement of German People," proposing that Germany exit the Treaty of Versailles. As authorities used radio to convince the population to withhold support for this proposed law, we find a negative significant effect of radio signal on the vote in favor of the proposed law during the referendum (columns 1-4 in Table 5). The results are robust to controlling for the Nazi vote share in the previous election, which took place one-and-a-half years before the referendum. We also consider the effect of radio availability on the results of the presidential election of 1932. We estimate equation (5) for the outcomes of the second tour of the presidential elections (the results are similar if we look at the results of the first round). We find that radio signal had a positive and significant effect on the vote share for von Hindenburg, the incumbent candidate supported by the radio news programs during the campaign, a negative but statistically insignificant effect on the vote for Hitler, who was the main opposition candidate, with p-values of 0.106 and 0.117 , i.e., very close to the conventional significance level (columns 5-8 of Table 5). ${ }^{22}$

\footnotetext{
${ }^{21} \mathrm{We}$ also looked at the cross-sectional regressions in which the level of Nazi vote share (rather than the difference in vote share from previous election) is related to the signal strength of German radio for each parliamentary election between March 1928 and March 1933. The results are presented in Table A4. We find that, in 1928, when radio was neutral and apolitical, radio availability did not affect Nazi vote share. During elections of September 1930, July 1932, and November 1932, radio signal strength became a negative significant predictor of Nazi vote share. In contrast, in the last competitive election, in March 1933, which took place less than six weeks after the Nazis took control over radio and initiated heavy propaganda, the negative effect of radio signal strength became much less pronounced and insignificant.

${ }^{22} \mathrm{We}$ also examine how radio availability affected voter turnout. Table A5 presents the results of the regressions estimating equation (1), with turnout as the dependent variable. We find a marginally significant negative effect of radio availability in July 1932, positive effect in November 1932, and no significant effect in either 1930 or 1933. Overall, there is no evidence of the consistent effect of radio availability on turnout at parliamentary elections.
} 
Given that the Nazis actively campaigned during all these years, employing various means of propaganda, one can test whether the effect of Nazi propaganda was uniform across districts that were and were not targeted by other means of propaganda, and in particular, Hitler's speeches. Table A6 in the appendix reports the results of regressions with the change in Nazi vote share between November 1932 and March 1933 as the dependent variable and the interaction between the number and the incidence of Hitler's speeches in the district in 1932 as the main dependent variables, controlling for the direct effects of Hitler's speeches and of radio availability. We find no significant interaction between Hitler's speeches and radio exposure: coefficients on the interaction term are insignificant, while the direct effect of radio signal is positive. One, however, should interpret these results with caution, as the location of Hitler's speeches in 1932 was chosen strategically to increase their political impact, which may have led to a selection bias in these difference-in-differences estimates.

Overall, our results on the effect of radio availability on voting outcomes while Germany was still a democracy are consistent with the hypothesis that radio played an important role in slowing down the Nazis' rise to power before they took control over radio, and that this effect was undone in the March 1933 election, after just one month of heavy proNazi radio propaganda.

\subsection{Did radio help the Nazis maintain political support after they consolidated power?}

Next, we examine whether and how radio helped the Nazis maintain public support for their policies after they came to power in March 1933, focusing on non-electoral outcomes.

First, we consider whether the radio propaganda helped the Nazi recruit new party members. Results are reported in Table 6. The sample consists of 633 (out of 958) districts with nonzero observations for party membership. We find that in 1932, when radio still had an anti-Nazi slant, the number of party members was not significantly related to radio availability (columns 1 and 2). It is not surprising, as those who join the party at that time were mostly the core Nazi supporters, whose preferences for the party was relatively strong. In contrast, in February-May of 1933, after the Nazis took over radio, party membership became significantly positively associated with radio signal strength (columns 3 and 4). Columns 5 and 6 show that party membership increased faster from the 1932 level in places where radio was available. The magnitude of the effect implies that approximately 13 percent of new 
NSDAP members were persuaded by radio propaganda during the first month of the Nazi control over the broadcast.

Second, we examine whether Nazi radio propaganda had an effect on expressions of anti-Semitism proxied by anti-Semitic letters to the official Nazi newspaper, Der Stürmer, attacks on synagogues during the Night of Broken Glass (Reichskristallnacht), and deportations of Jews between 1933 and 1942. These variables are measured at the city level for 1,216 locations. We estimate equation (5) with these measures of anti-Semitism as dependent variables and radio signal strength in 1935 as the main explanatory variable. ${ }^{23}$ In city-level analysis, the set of controls differs from the district-level analysis in two ways. First, we control for log of city population instead of the fifth-order polynomial because the variation in city population is much smaller than between cities and rural areas. Second, in regressions with attacks on synagogues as the dependent variable, we add a dummy for the presence of a synagogue in the city. Table 7 presents the results. We find that, on average, the exposure to Nazi radio significantly increased the number of letters to Der Stürmer and the number of deportations of Jews. We find no significant average effect of radio on the attacks on synagogues (while the point estimate is positive).

The average effect of radio exposure on the expression anti-Semitisms masks important heterogeneity of the effect of radio propaganda depending on listeners' priors with regard to the broadcasted message, in particular, historic predisposition of city population to antiSemitism. To address this question, we estimate an augmented specification where we add the incidence of pogroms in 1349 and its interaction with radio signal strength as additional covariates, where pogroms in 1349 capture a historic predisposition of city population to antiSemitism. The analysis is confined to the subsample of cities with Jewish settlements in 1349, as the measure of historical anti-Semitism is meaningful only in this subsample (Voigtländer and Voth 2012). Table 8 reports the results. We find that the coefficient on the interaction term between pogroms in 1349 and radio availability in 1935 is positive and statistically significant for the number of letters to Der Stürmer and for the number of deportations. The coefficient is also positive, but imprecisely estimated for the attacks on synagogues. These results indicate that Nazi radio propaganda had a larger effect on the expressions of anti-Semitism in cities

\footnotetext{
${ }^{23}$ The results are robust to using signal strength for later periods.
} 
with more anti-Semitic population. In places with positively predisposed population, propaganda was very effective: the point estimates of the effect of the radio propaganda on the expressions of anti-Semitism are 3 to 4 times larger for cities which witnessed historical pogroms compared to the average city (as seen from the comparison of the first rows of Tables 7 and 8). In contrast, for cities where pogroms did not occur during the Black Death despite having historical Jewish settlement, the effect of radio signal strength was negative as reflected in the negative and significant coefficients on the radio signal strength in Table 8 for both the letters to Der Stürmer and for the number of deportations. Again, the results for the attacks on synagogues have the right sign, but are statistically insignificant. This result suggests that the population in places with historically low anti-Semitism reacted negatively to the Nazi radio propaganda. Thus, when the listeners are negatively predisposed, propaganda may actually be dissuasive, rather than persuasive. ${ }^{24}$

Overall, these results confirm that the exposure to Nazi radio propaganda increased the frequency of expressions of anti-Semitism by ordinary Germans on average and that the propaganda was most effective on listeners who were predisposed to the message but it backfired when listeners were negatively predisposed to the message.

\subsection{Persuasion rates}

In order to understand the magnitude of the effects and assess the relative effectiveness of proNazi and anti-Nazi radio propaganda, we compute persuasion rates, i.e., the fraction of the audience of a media outlet (German radio) who were convinced to change their behavior as a result of being exposed to this media. We use the formula for a continuous measure of radio exposure introduced by Enikolopov et al. (2011). ${ }^{25}$ This formula yields the effect of an

\footnotetext{
${ }^{24}$ We also tried to use the vote for the German National People's Party (DFVP) in 1924, which was a legal rightwing party, as a possible measure of positive predisposition to the Nazi propaganda. The interaction between radio signal and the vote for DFVP in 24 is positive, as predicted, but often imprecisely estimated. These results, presented in online appendix Table A7, are broadly consistent with our finding that predispositions to the message of the propaganda matter. The vote for DFVP is, however, a very noisy proxy for anti-Semitism, because to a large extent it was determined by the party's relative position on economic issues, which were salient for the 1924 election. The noisiness of this variable explains the lack of statistical significance of the interaction. Note also that, in contrast to the historical pogrom variable, one should not expect a negative direct effect of radio propaganda, as zero vote for DFVP in 1924 does not indicate the absence anti-Semitism in the district.

${ }^{25}$ This formula differs from the first formula for persuasion rates derived by DellaVigna and Kaplan (2007) in the
} 
infinitesimally small change in media exposure taking into account the effect of turnout and controlling for the fraction of people who could potentially be persuaded (i.e., who would not have voted in favor of the message without being exposed to the media).

For the 1933 election, we compute the persuasion rate for the message of the Nazi propaganda - "vote for NSDAP" — using the following formula:

$f=\frac{1}{1-v_{0} t_{0}}\left(t \frac{d v}{d e}+v \frac{d t}{d e}\right)=\frac{1}{1-v_{0} t_{0}} \cdot \frac{1}{d e / d s}(t \cdot d v / d s+v \cdot d t / d s)$,

where $v$ is vote share of NSDAP, $t$ is turnout, $v_{0}$ and $t_{0}$ are Nazi vote share and turnout in the absence of radio, ${ }^{26} d v / d s$ is the effect of the change in radio signal strength on Nazi vote share (column 8 of Table 3 ), $d t / d s$ is the corresponding effect for turnout (column 8 of Table A5), and $d e / d s$ is the effect of the change in radio signal strength on the listenership share (column 4 of Table 1). We evaluate $f$ at $t=t_{0}$ and $v=v_{0}$. Note that our out best proxy for the listenership measure is the radio subscription rate. Thus, in order to apply this formula, we need to multiply the subscription rate by the average number of adult radio listeners per subscription. Under the assumption that, on average, four people listened to the radio with one subscription, the persuasion rate of the message of the pro-Nazi radio propaganda- "vote for NSDAP"-was equal to:

$f=[1 /(1-0.464 * 0.877)] *[1 /(0.0017 * 4)] *(0.045 * 0.877+0.464 * 0.029)=13.1 \%$.

Voters who could potentially respond to the message of the Weimar government— "do not vote for the Nazis, vote for other parties"-are only those who in the absence of radio would have voted for the Nazis. Thus, the formula for the negative message takes the following form:

following three respects: (1) it focuses on the case of continuous exposure by analyzing the effect of an infinitesimal change in radio exposure; (2) it allows turnout to increase or decrease for voters exposed to radio broadcasts, as some people who would have voted in the absence of the message may decide to abstain from turning up for the election, which is the case in our data; (3) it allows us to compute separately persuasion rates for a positive message (i.e., encouragement to vote for a specific party) or for a negative message (i.e., discouragement to vote for a specific party). Note that the difference between the effects of positive and negative messages is particularly important in a multiparty system such as Germany's.

${ }^{26}$ The numbers are calculated as the predicted values of the vote share for the NSDAP and turnout from the regression reported in column 10 of Table A4 and a similar regression for turnout calculated at the minimum level of signal strength observed in the sample. 
$f=\frac{1}{-v_{0} t_{0}}\left(t \frac{d v}{d e}+v \frac{d t}{d e}\right)=\frac{1}{-v_{0} t_{0}} \cdot \frac{1}{d e / d s}(t \cdot d v / d s+v \cdot d t / d s)$

As in the case of the message of the Nazi propaganda, we estimate persuasion rate at $t=t_{0}$ and $\mu=\mu_{0}$. As $d v /_{d s}$ we take the coefficient on the effect of radio signal strength on change in Nazi vote share from column 2 in Table 4. As the effect of radio signal strength on turnout in 1930 is not significant (see column 2 in Table A5) we take $d t / d s=0$ and $t_{0}$ is taken as the mean turnout in 1930 from Table A1. Again, assuming that there were, on average, four listeners per subscription, the persuasion rate in 1930 was equal to:

$f=-[1 /(0.181 * 0.808)] *[1 /(0.00252 * 4)]^{*}(-0.051 * 0.808)=28.0 \%$.

These persuasion rates are comparable with the range of persuasion rates of media estimated by the literature in a democratic setting. In particular, the persuasion rate of proNazi radio propaganda is larger than that of Fox News Channel (12\%), as reported in DellaVigna and Kaplan (2007), and is lower than the persuasion rate of the Washington Post $(20 \%)$, as reported by Gerber, Karlan, and Bergan (2009). The persuasion rate of anti-Nazi radio content, before 1933, is half of the size of the persuasion rate for the negative message "do not vote for pro-governmental party" of an independent Russian TV channel (65\%) in Enikolopov et al. (2011).

\subsection{Placebo tests}

To provide additional evidence in favor of our identification assumptions we show that German radio availability is not associated with outcomes that it was not supposed to affect. Specifically, we test whether radio signal strength in 1928 affected the change in the share of votes received by extremist parties between 1924 and 1928. One should not expect any effect because radio was apolitical in that period. In addition, we verify that the share of votes received by the two right-wing parties (DNVP and NSBF) in parliamentary elections in December 1924 is not related to the radio signal strength in 1928. We also examine whether the signal strength in 1930 (the first year in which we find significant effect of radio on the vote for the NSDAP) was associated with any voting outcomes in 1920 and 1924 (when radio was used only by the military), with voting in the presidential election of 1925 (when radio listenership was still very small and radio coverage was neutral). Analogous to our estimations for the effect of radio on the expression of anti-Semitism we look at the effect of signal 
strength in 1935 on crime rates from 1900 to 1920 and anti-Jewish pogroms in 1920s. We do not find significant association between radio availability and any of these placebo outcomes (see Table 9$),{ }^{27}$ which bolsters our identification assumptions.

\section{Conclusions}

In the context of the Weimar Republic and the early Third Reich, we examine which role mass media played during the process of dismantling of the democratic institutions and after the full consolidation of the dictatorship. We find that relatively mild anti-Nazi slant in radio news programs between 1929 and 1932 was effective in substantially reducing the Nazi Party vote in three consecutive parliamentary elections. In 1933, Nazis took control over radio and began airing heavily pro-Nazi propaganda; in just one month, this fully undid the effect of anti-Nazi radio of the previous four years.

After the Nazis fully consolidated power, radio propaganda was instrumental in ensuring public support for the regime. It helped the Nazis enroll new party members and encouraged denunciations of Jews, leading to their deportation to concentration camps and causing open expressions of anti-Semitism, such as writing anti-Semitic letters to the national newspaper. The effects of the Nazi propaganda on expressions of anti-Semitism were particularly pronounced when the message was aligned with listeners' predispositions, i.e., a more anti-Semitic audience, as measured by the historical anti-Semitism in the location, was more easily convinced by Nazi radio propaganda. In contrast, propaganda was counterproductive when the message was contradicting listeners' priors: the least anti-Semitic audience, measured by historical anti-Semitism, reacted negatively to the Nazi radio.

Our findings suggest that mass media plays an important role in the process of institutional change. In particular, restrictions of extremist speech are an important element helping mass media to serve as a safeguard of democracy. Without such restrictions, mass media can become an important catalyst of the establishment of a dictatorial rule, if future dictators get control over the content. We also show that propaganda in an established

\footnotetext{
${ }^{27}$ One exception is vote for DVFP (pre-Nazi right-wing extremist party) in 1920, significant at $10 \%$ level, in 1 out of 18 placebo tests. Note, however, that it is positively correlated with radio signal strength in 1930, in contrast to negative relationship between Nazi party vote share and the signal strength in 1930.
} 
dictatorial regime contributes to its stability and dictator's popularity, but only among audiences that are positively predisposed to the propaganda's message.

\section{References}

Acemoglu, Daron and Robinson, James A. 2006. Economic Origins of Dictatorship and Democracy. Cambridge, UK: Cambridge University Press.

Acemoglu, Daron and Robinson, James A. 2012. Why Nations Fail: The Origins of Power, Prosperity, and Poverty. New York: Random House LLC

Altonji J., T. Elder, and C. Taber (2005) Selection on Observed and Unobserved Variables: Assessing the Effectiveness of Catholic Schools. Journal of Political Economy, 113(1), 151-184.

Bausch, Hans (1956) Der Rundfunk im politischen Kräftespiel der Weimarer Republik 19231933. J.C.B. Mohr (Paul Siebeck): Tübingen.

Besley, T., Prat, A. (2006) "Handcuffs for the grabbing hand: media capture and government accountability." American Economic Review 96 (3), 720-736.

Brustein, William, and Jürgen Falter (1995) "Who Joined the Nazi Party? Assessing Theories of the Social Origins of Nazism", Zeitgeschichte22 (3/4): 83-108.

Bundesarchiv (2007), Gedenkbuch Opfer der Verfolgung der Juden unter der Nationalsozialistischen Gewaltherrschaft in Deutschland, 1933-1945. Koblenz: Bundesarchiv.

Cebulla, Florian (2004) Rundfunk und ländliche Gesellschaft 1924-1945. Ruprecht Gmbh \& Company: Göttingen.

Childers, Thomas (1983) The Nazi Voter: The Social Foundations of Fascism in Germany, 1919-1933. Chapel Hill: University of North Carolina Press.

DellaVigna, Stefano, and Ethan Kaplan (2007). "The Fox news effect: media bias and voting." Quarterly Journal of Economics, 122(3): 807-860.

DellaVigna, Stefano, Ruben Enikolopov, Vera Mironova, Maria Petrova, and Ekaterina Zhuravskaya (forthcoming). "Cross-border effects of foreign media: Serbian radio and nationalism in Croatia." American Economic Journal: Applied Economics

DellaVigna, Stefano and Gentzkow, Matthew (2010), "Persuasion: empirical evidence." Annual Review of Economics, 2(1): 643-669.

Diller, Ansgar (1980) Rundfunkpolitik im Dritten Reich. München.

Dussel, Konrad (2010) Deutsche Rundfunkgeschichte, 3 überarbeitete Auflage, Konstanz: UKV.

Durante, Ruben and Brian Knight (2012). "Partisan Control, Media Bias, and Viewer Responses: Evidence from Berlusconi's Italy," Journal of the European Economic Association, 10(3): 451-481. 
Egorov, Georgy, Sergei Guriev and Konstantin Sonin (2009). "Why resource-poor dictators allow freer media: a theory and evidence from panel data." American Political Science Review. 103(4): 645-668.

Enikolopov, Ruben, Maria Petrova, and Ekaterina Zhuravskaya (2011). "Media and political persuasion: evidence from Russia." American Economic Review, 111(7): 3253-3285.

Falter, Jurgen W. (1991) Hitlers Wähler. Munich: C. H. Beck.

Falter, Jürgen and Dirk Hänisch (1990). "Wahl- und Sozialdaten der Kreise und Gemeinden des Deutschen Reiches von 1920 bis 1933." GESIS Datenarchiv, Köln. ZA8013 Datenfile Version 1.0.0, doi:10.4232/1.8013.

Ferguson, Thomas and Hans-Joachim Voth (2008). "Betting on Hitler: the value of political connections in Nazi Germany." Quarterly Journal of Economics, 123(1): 101-137.

Gellately, R. (2001) Backing Hitler. Oxford University Press.

Gehlbach, S., and K. Sonin (2011) "Government control of media," working paper

Gentzkow, M. (2006) “Television and voter turnout.” Quarterly Journal of Economics 121(3), 931-972.

Gentzkow, M., J. M. Shapiro and M. Sinkinson (2011) "The Effect of Newspaper Entry and Exit on Electoral Politics," American Economic Review. 101 (7).

Gerber, Alan, Dean Karlan and Daniel Bergan, D. (2009). "Does the media matter? A field experiment measuring the effect of newspapers on voting behavior and political opinions." American Economic Journal: Applied Economics, 1(2): 35-52.

Hänisch, Dieter (1988) Wahl- und Sozialdaten der Kreise und Gemeinden des Deutschen Reiches 1920-1933, Database ZA8013 (Berlin: Leibniz-Institut für Sozialwissenschaften-GESIS, 1988).

Hufford, G.A. (2002) The ITS Irregular Terrain Model, Version 1.2.2 the Algorithm. Available: http://flattop.its.bldrdoc.gov/itm.html.

King, Gary; Ori Rosen; Martin A. Tanner; and Alexander F. Wagner (2008). "Ordinary economic voting behavior in the extraordinary election of Adolf Hitler." Journal of Economic History, 68(4): 951-996.

Knight B., Chiang C. (2011) "Media bias and influence: Evidence from newspaper endorsements." Review of Economic Studies, 78(3), 795-820.

Lerg, Winfried B. (1980). Rundfunkpolitik in der Weimarer Republik. Deutscher Taschenbuch Verlag.

Olken Benjamine (2009). "Do TV and radio destroy social capital? Evidence from Indonesian villages." American Economic Journal: Applied Economics, 1(4): 1-33.

Paul, Gerhard (1992 [1933]) Aufstand der Bilder, Die NS-Propaganda vor 1933. Bonn.

Pohle, Heinz (1955) Der Rundfunk als Instrument der Politik: Zur Geschichte d. Dt. Rundfunks von 1923/1938. Verlag Hans Bredow-Inst.: Hamburg.

Ross, Corey (2006). "Mass politics and the techniques of leadership: the promise and perils of propaganda in Weimar Germany." German History, 24(2). 
Satyanath, Shanker, Nico Voigtländer, Nico, and Hans-Joachim Voth (2013) "Bowling for fascism: Social capital and the rise of the Nazi Party in Weimar Germany, 1919-33," NBER working paper 19201.

Shirer, William (1960). The Rise and Fall of the Third Reich: A History of Nazi Germany. Simon \& Schuster.

Schütte, Wolfgang (1971) "Regionalität und Föderalismus im Rundfunk." Die geschichtliche Entwicklung in Deutschland 1923-1945. Knecht.

Sington, C and A. Weidenfeld (1943). The Goebbels Experiment: A Study of the Nazi Propaganda Machine. New Haven.

Somerville (2012). Radio Propaganda and the Broadcasting of Hatred. Palgrave MacMillan, New York.

Strömberg, David (2004). "Radio's impact on public spending." Quarterly Journal of Economics, 119(1): 189-221.

Vaessen, Kurt (1938) "Daten aus der Entwicklung des Rundfunks. Mit Vergleichszahlen aus der Geschichte des Films, der Presse und des Verkehrswesens" Würzburg: Triltsch

Voigtländer, Nico, and Hans-Joachim Voth (2012). "Persecution perpetuated: medieval origins of anti-Semitic violence in Nazi Germany." Quarterly Journal of Economics, 127(3): 1339-1392.

Vollmann, Heinz (1936). Rechtlich-wirtschaftlich-soziologische Grundlagen der deutschen Rundfunk-Entwicklung. Leipzig.

Weiss, Heinz (1943). Rundfunk im Aufbruch. Handbuch des deutschen Rundfunks 1934 mit Funkkalender. Mit einem Geleitwort von Reichsminister Pg. Dr. Goebbels, Reichsverband Deutscher Rundfunkteilnehmer (R.D.R.) E.V. Berlin.

Yanagizawa-Drott, David (2012). "Propaganda and conflict: theory and evidence from the Rwandan genocide." working paper

Zimmermann, Clemens (2006). "From propaganda to modernization: media policy and media audiences under national socialism." German History, Vol. 24 No. 3. 
Figure 1. Timeline of key political events.

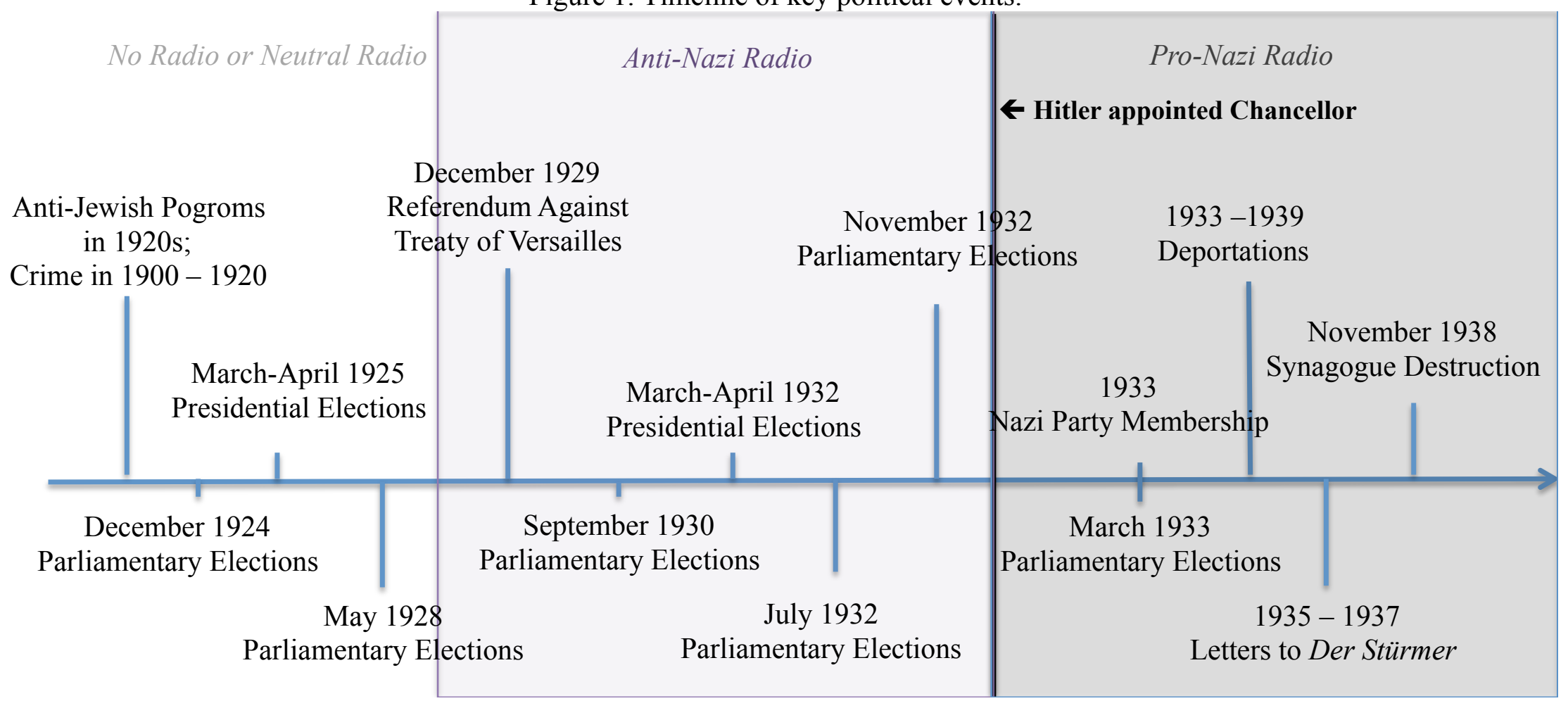


Figure 2. Number of Radio Subscriptions in Germany, 1924 - 1933.

Green lines - dates of parliamentary elections

Red lines - dates of presidential elections

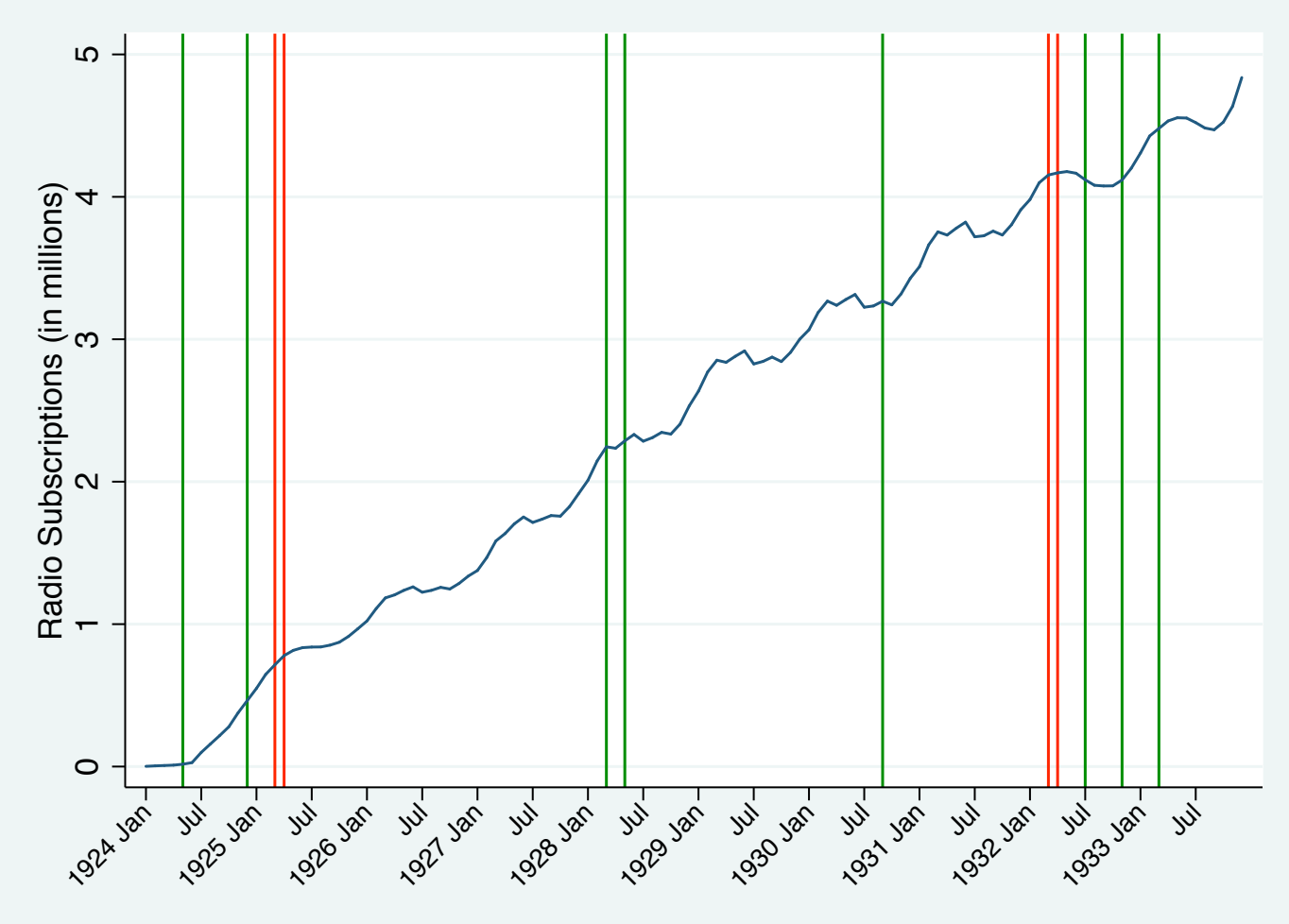


Figure 3. Radio Signal Strength in Germany. Variation conditional on urbanization and province fixed effects.

A. May 1928

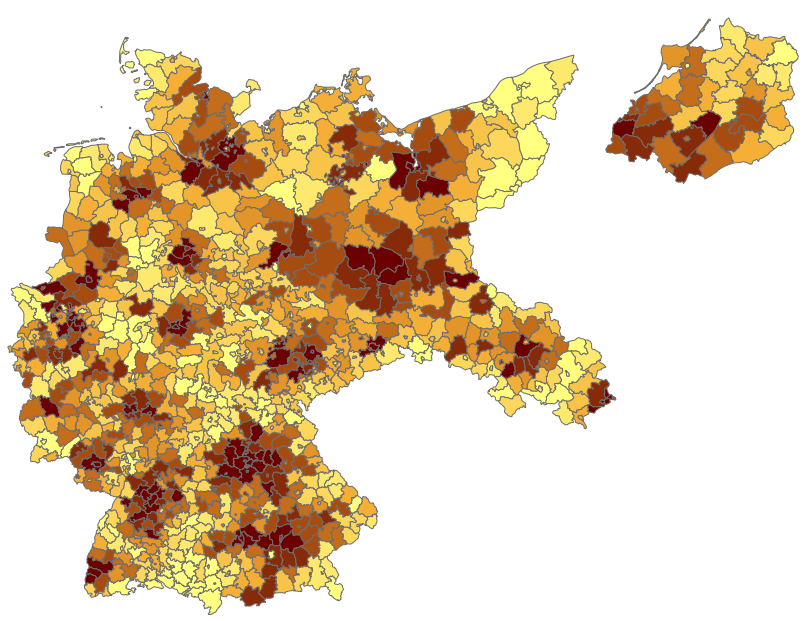

C. July 1932

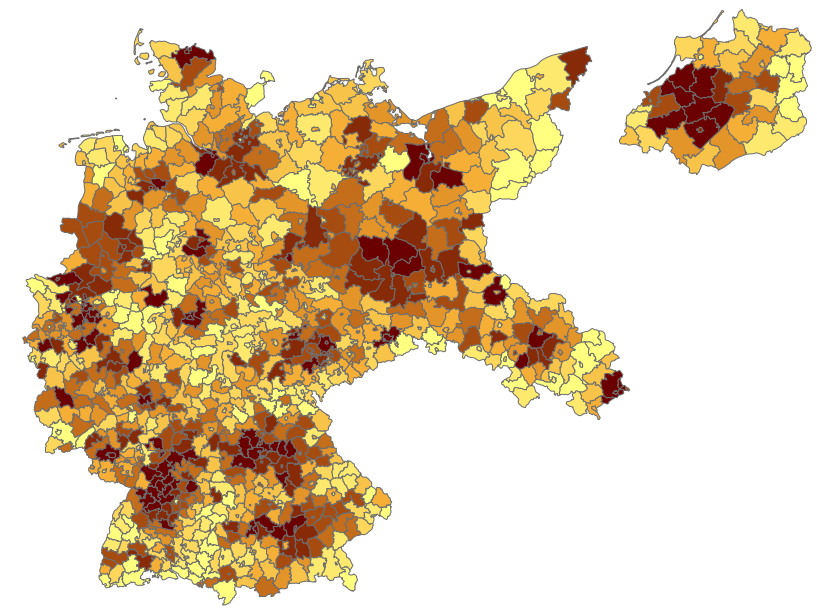

B. September 1930

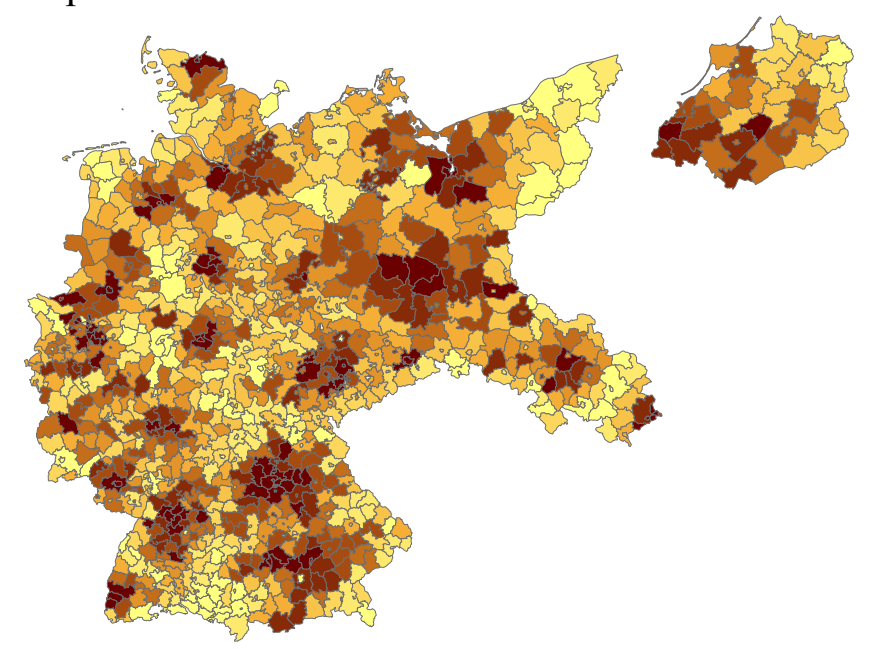

D. March 1933

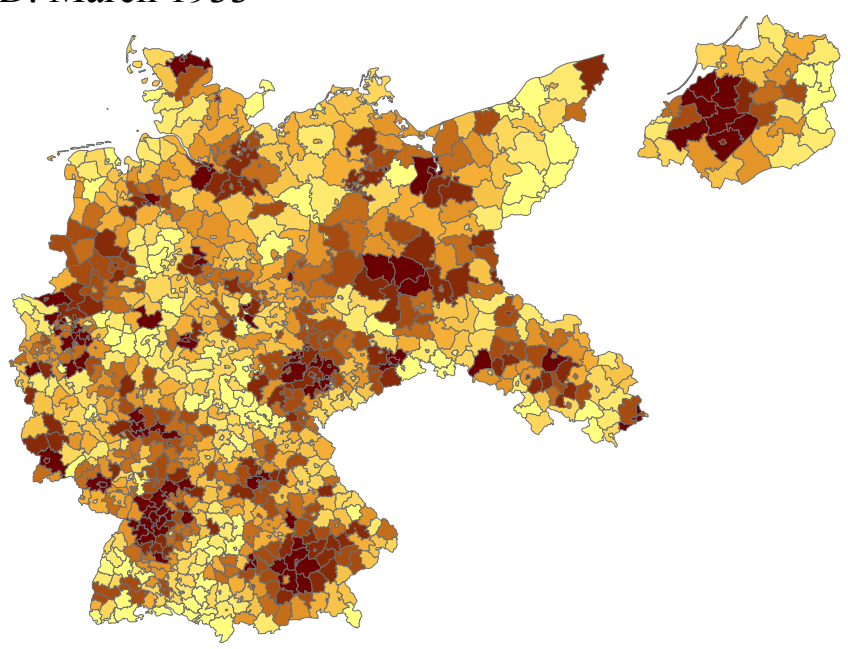


Figure 4A. Radio Subscriptions and Signal Strength, 1931 (no controls). t-statistics for bivariate relationship: 14.12

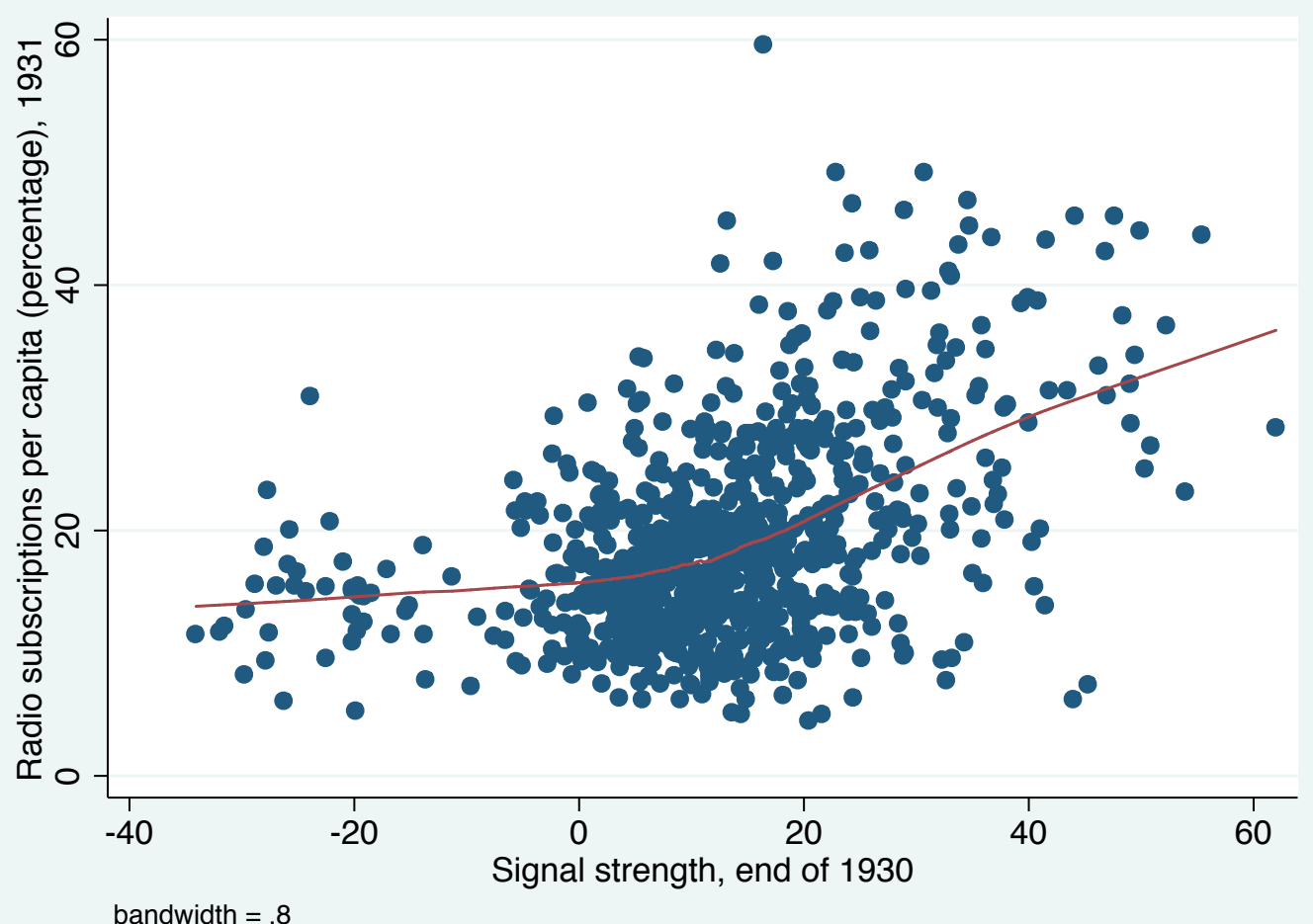

Figure 4B. Radio Subscriptions and Signal Strength, 1931 (with controls). $\mathrm{t}$-statistics for signal strength conditional on all controls: 10.10

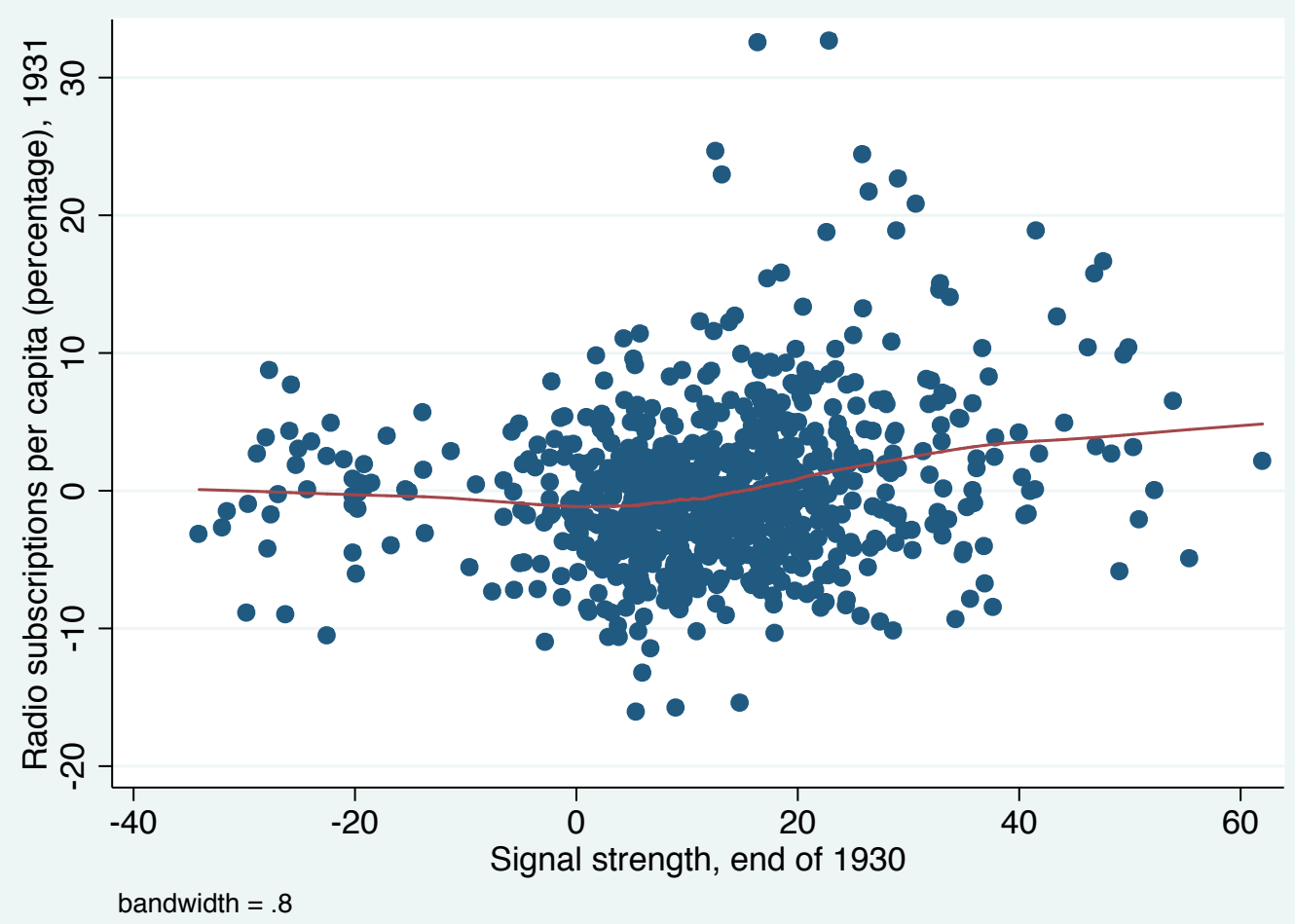


Figure 5. Radio effect estimates for signal strength and its leads and lags.

Dependent variable: change in vote share for Nazi party since previous elections. Different colors correspond to different elections; different bars of the same color represent results for leads and lags of signal strength. $10 \%$ error bars are shown.

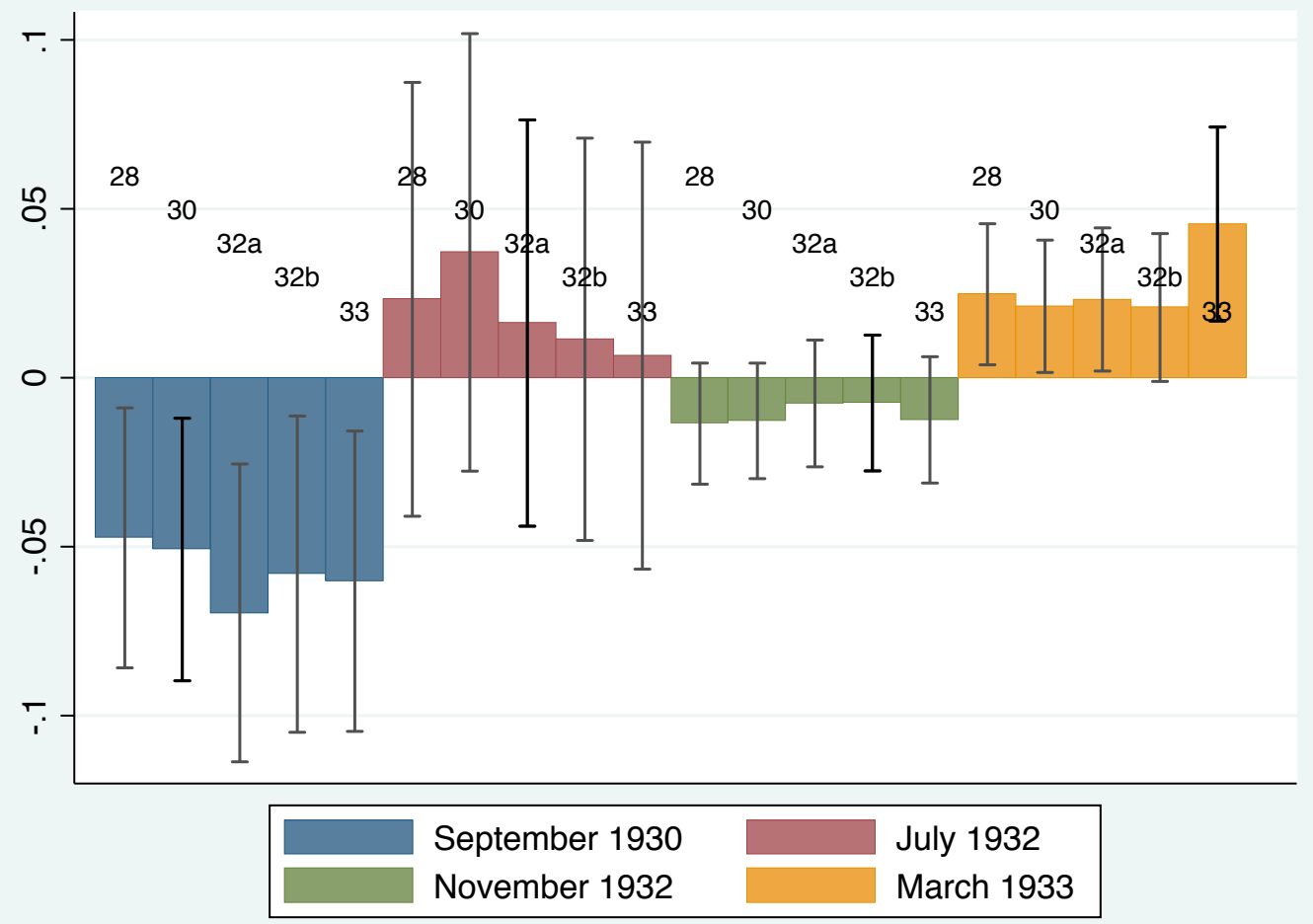


Table 1. Radio Listenership and Radio Availability

\begin{tabular}{|c|c|c|c|c|c|}
\hline & \multicolumn{5}{|c|}{ Percentage of population with a license to listen to radio } \\
\hline & $\begin{array}{c}\text { September } 1930 \\
\text { (1) }\end{array}$ & $\begin{array}{c}\text { July } 1932 \\
\text { (2) }\end{array}$ & $\begin{array}{c}\text { November } 1932 \\
\text { (3) }\end{array}$ & $\begin{array}{c}\text { March } 1933 \\
(4)\end{array}$ & $\begin{array}{c}\text { Panel } 1930-1933 \\
\text { (5) }\end{array}$ \\
\hline Radio signal strength & $\begin{array}{l}0.243^{* * *} \\
{[0.031]}\end{array}$ & $\begin{array}{l}0.205^{\star * *} \\
{[0.027]}\end{array}$ & $\begin{array}{l}0.193^{* * *} \\
{[0.030]}\end{array}$ & $\begin{array}{c}0.170^{* * *} \\
{[0.041]}\end{array}$ & $\begin{array}{l}0.058^{\star \star *} \\
{[0.017]}\end{array}$ \\
\hline Share of Jewish population, 1925 & $\begin{array}{c}49.612 \\
{[58.562]}\end{array}$ & $\begin{array}{c}51.871 \\
{[62.779]}\end{array}$ & $\begin{array}{c}51.19 \\
{[64.351]}\end{array}$ & $\begin{array}{c}95.156 \\
{[69.310]}\end{array}$ & \\
\hline Share of Catholic population, 1925 & $\begin{array}{l}-7.147^{* *} \\
{[2.729]}\end{array}$ & $\begin{array}{c}-7.003^{* *} \\
{[3.104]}\end{array}$ & $\begin{array}{c}-7.131^{\star *} \\
{[3.060]}\end{array}$ & $\begin{array}{l}-5.999^{*} \\
{[3.062]}\end{array}$ & \\
\hline Share of blue-collar workers, 1925 & $\begin{array}{l}-4.430^{*} \\
{[2.476]}\end{array}$ & $\begin{array}{c}-7.976^{* * *} \\
{[2.572]}\end{array}$ & $\begin{array}{c}-7.713^{* * *} \\
{[2.631]}\end{array}$ & $\begin{array}{c}-8.648^{* * *} \\
{[2.897]}\end{array}$ & \\
\hline Share of white-collar workers, 1925 & $\begin{array}{l}10.289 \\
{[8.208]}\end{array}$ & $\begin{array}{l}16.966^{*} \\
{[8.518]}\end{array}$ & $\begin{array}{l}15.594^{*} \\
{[8.840]}\end{array}$ & $\begin{array}{c}22.351^{* *} \\
{[9.497]}\end{array}$ & \\
\hline City (Stadtkreis) & $\begin{array}{c}0.595 \\
{[1.246]}\end{array}$ & $\begin{array}{l}0.514 \\
{[1.251]}\end{array}$ & $\begin{array}{l}0.913 \\
{[1.273]}\end{array}$ & $\begin{array}{l}-1.048 \\
{[1.343]}\end{array}$ & \\
\hline War participants per 1,000 & $\begin{array}{l}0.106 \\
{[0.101]}\end{array}$ & $\begin{array}{c}0.117 \\
{[0.095]}\end{array}$ & $\begin{array}{c}0.109 \\
{[0.097]}\end{array}$ & $\begin{array}{c}0.012 \\
{[0.115]}\end{array}$ & \\
\hline Welfare recipients per 1,000 & $\begin{array}{c}0.001 \\
{[0.001]}\end{array}$ & $\begin{array}{c}0.001 \\
{[0.001]}\end{array}$ & $\begin{array}{c}0.001 \\
{[0.001]}\end{array}$ & $\begin{array}{c}0 \\
{[0.001]}\end{array}$ & \\
\hline Pensioners with social assistance per 1,000 & $\begin{array}{c}0.007 \\
{[0.050]}\end{array}$ & $\begin{array}{l}-0.028 \\
{[0.049]}\end{array}$ & $\begin{array}{l}-0.028 \\
{[0.050]}\end{array}$ & $\begin{array}{l}-0.064 \\
{[0.058]}\end{array}$ & \\
\hline Log of average property tax payment & $\begin{array}{c}0.958 \\
{[0.573]}\end{array}$ & $\begin{array}{l}1.268^{\star *} \\
{[0.567]}\end{array}$ & $\begin{array}{l}1.249^{* *} \\
{[0.583]}\end{array}$ & $\begin{array}{l}1.796^{* * *} \\
{[0.594]}\end{array}$ & \\
\hline Population, fifth-order polynomial & Yes & Yes & Yes & Yes & No \\
\hline Voting controls, 1924 & Yes & Yes & Yes & Yes & No \\
\hline Province fixed effects & Yes & Yes & Yes & Yes & No \\
\hline Pogrom controls, 1349 & Yes & Yes & Yes & Yes & No \\
\hline Unemployment controls, 1933 & Yes & Yes & Yes & Yes & No \\
\hline Control variables interacted with period fixed effects & No & No & No & No & Yes \\
\hline Period fixed effects & No & No & No & No & Yes \\
\hline District fixed effects & No & No & No & No & Yes \\
\hline Observations & 810 & 835 & 835 & 836 & 3316 \\
\hline R-squared & 0.59 & 0.54 & 0.53 & 0.50 & 0.74 \\
\hline
\end{tabular}

Note: Standard errors clustered by province (Wahlkreis) in parentheses. ${ }^{*} p<0.1,{ }^{* *} p<0.05,{ }^{* * *} p<0.01$. Voting controls include turnout and vote shares of DNVP, NSFB, SPD, and Zentrum in 1924. Unemployment controls include share of unemployed and the share of people without full-time employment. Pogrom controls include dummy for pogroms in 1349 and a dummy for a Jewish settlement in 1349. Pogrom controls are not significant in all specifications. Number of observations varies because of missing data on listenership and because of redistricting. 
Table 2A. Determinants of Radio Availability

\begin{tabular}{|c|c|c|c|c|c|c|c|c|c|c|}
\hline & \multicolumn{10}{|c|}{ Radio Signal Strength } \\
\hline & \multicolumn{2}{|c|}{ March 1928} & \multicolumn{2}{|c|}{ September 1930} & \multicolumn{2}{|c|}{ July 1932} & \multicolumn{2}{|c|}{ November 1932} & \multicolumn{2}{|c|}{ March 1933} \\
\hline & (1) & $(2)$ & (3) & $(4)$ & $(5)$ & (6) & $(7)$ & (8) & (9) & (10) \\
\hline \multirow[t]{2}{*}{ Share of Jewish population, 1925} & -86.225 & -86.279 & -95.877 & -95.882 & -15.342 & -18.032 & -13.016 & -15.116 & -82.242 & -86.519 \\
\hline & [101.591] & [106.443] & [98.404] & [102.864] & [119.227] & [124.004] & {$[109.620]$} & {$[113.897]$} & [86.098] & [89.203] \\
\hline \multirow[t]{2}{*}{ Share of Catholic population, 1925} & -2.056 & -2.018 & -3.723 & -3.686 & -4.452 & -4.365 & -4.389 & -4.301 & -2.149 & -2.004 \\
\hline & [4.283] & {$[4.236]$} & [4.388] & {$[4.340]$} & [3.645] & [3.584] & {$[3.470]$} & [3.418] & {$[4.587]$} & {$[4.512]$} \\
\hline \multirow[t]{2}{*}{ Share of blue-collar workers, 1925} & $7.048^{*}$ & 5.091 & $7.755^{\star}$ & 5.913 & $10.731^{* *}$ & $8.755^{\star}$ & $9.521^{*}$ & 8.068 & $10.096^{* *}$ & $8.258^{*}$ \\
\hline & {$[4.091]$} & [4.193] & [3.972] & [4.118] & [4.895] & [4.973] & {$[4.820]$} & {$[4.914]$} & [4.563] & [4.772] \\
\hline \multirow[t]{2}{*}{ Share of white-collar workers, 1925} & $-14.122^{\star *}$ & $-16.021^{* *}$ & $-12.049^{*}$ & $-13.745^{\star *}$ & $-18.944^{* *}$ & $-19.381^{* *}$ & $-14.743^{*}$ & $-14.954^{*}$ & -14.202 & -13.688 \\
\hline & [6.779] & [6.329] & [6.595] & [6.149] & [8.124] & [8.136] & {$[7.647]$} & [7.795] & {$[8.498]$} & [8.606] \\
\hline \multirow[t]{2}{*}{ City (Stadtkreis) } & $4.409^{* * *}$ & $3.582^{* * *}$ & $4.332^{* * *}$ & $3.549^{* * *}$ & $5.143^{* * *}$ & $4.431^{* * *}$ & $4.603^{* * *}$ & $4.041^{* * *}$ & $4.725^{\star * *}$ & $4.114^{* * *}$ \\
\hline & {$[1.306]$} & {$[1.175]$} & [1.401] & {$[1.273]$} & {$[1.445]$} & [1.292] & [1.441] & {$[1.301]$} & [1.522] & [1.430] \\
\hline War participants per 1,000 & -0.102 & $-0.125^{*}$ & $-0.156^{*}$ & $-0.177^{* *}$ & -0.123 & $-0.143^{*}$ & -0.036 & -0.051 & -0.169 & -0.187 \\
\hline \multirow[t]{2}{*}{ Welfare recipients per 1,000} & 0.001 & 0.001 & 0.001 & 0.001 & -0.001 & 0.000 & 0.000 & 0.000 & 0.002 & 0.002 \\
\hline & [0.002] & [0.002] & [0.002] & {$[0.001]$} & {$[0.001]$} & {$[0.001]$} & [0.001] & {$[0.001]$} & [0.002] & [0.002] \\
\hline \multirow[t]{2}{*}{ Pensioners with social assistance per 1,000} & -0.074 & -0.075 & -0.039 & -0.039 & -0.082 & -0.076 & -0.078 & -0.073 & -0.061 & -0.052 \\
\hline & {$[0.105]$} & {$[0.104]$} & {$[0.103]$} & {$[0.103]$} & {$[0.089]$} & {$[0.090]$} & {$[0.089]$} & {$[0.091]$} & {$[0.084]$} & {$[0.087]$} \\
\hline \multirow[t]{2}{*}{ Log of average property tax payment } & -0.243 & -0.141 & -0.417 & -0.316 & -0.762 & -0.661 & -0.800 & -0.724 & -0.220 & -0.134 \\
\hline & {$[0.661]$} & {$[0.658]$} & {$[0.656]$} & {$[0.648]$} & {$[0.545]$} & {$[0.536]$} & {$[0.531]$} & {$[0.517]$} & {$[0.679]$} & {$[0.668]$} \\
\hline Population, fifth-order polynomial & Yes & Yes & Yes & Yes & Yes & Yes & Yes & Yes & Yes & Yes \\
\hline Voting controls, 1924 & Yes & Yes & Yes & Yes & Yes & Yes & Yes & Yes & Yes & Yes \\
\hline Province fixed effects & Yes & Yes & Yes & Yes & Yes & Yes & Yes & Yes & Yes & Yes \\
\hline Pogrom controls, 1349 & Yes & Yes & Yes & Yes & Yes & Yes & Yes & Yes & Yes & Yes \\
\hline Unemployment controls, 1933 & No & Yes & No & Yes & No & Yes & No & Yes & No & Yes \\
\hline Observations & 960 & 960 & 960 & 960 & 960 & 960 & 960 & 960 & 960 & 960 \\
\hline R-squared & 0.62 & 0.62 & 0.63 & 0.63 & 0.55 & 0.55 & 0.57 & 0.57 & 0.53 & 0.53 \\
\hline F-statistics, voting controls from 1924 & 10.70 & 10.62 & 10.93 & 10.93 & 12.95 & 12.60 & 11.22 & 11.08 & 13.16 & 12.82 \\
\hline
\end{tabular}

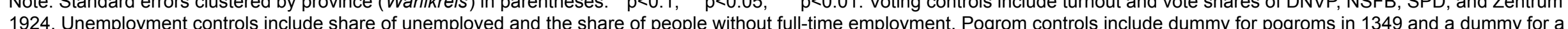

Jewish settlement in 1349. Pogrom controls are not significant in all specifications. 


\section{Table 2B. Altonji-Elder-Taber Test}

\begin{tabular}{|c|c|c|c|c|}
\hline & \multicolumn{4}{|c|}{ Change in Nazi vote share } \\
\hline & $\begin{array}{c}\text { May 1928- } \\
\text { September } 1930 \\
(1)\end{array}$ & $\begin{array}{c}\text { September 1930- } \\
\text { July1932 } \\
(2)\end{array}$ & $\begin{array}{c}\text { July 1932-Nov } 1932 \\
\text { (3) }\end{array}$ & $\begin{array}{c}\text { Nov 1932-Mar } 1933 \\
\text { (4) }\end{array}$ \\
\hline Index of observables & -0.0719 & -0.0486 & 0.0449 & -0.084 \\
\hline (Prediction of signal strength) & {$[0.153]$} & {$[0.250]$} & [0.088] & [0.106] \\
\hline Population, fifth polynomial & Yes & Yes & Yes & Yes \\
\hline Province fixed effects & Yes & Yes & Yes & Yes \\
\hline City ( Stadtkreis) & Yes & Yes & Yes & Yes \\
\hline Observations & 959 & 959 & 919 & 918 \\
\hline \multirow[t]{2}{*}{ R-squared } & 0.43 & 0.42 & 0.38 & 0.60 \\
\hline & $\begin{array}{l}\text { Voted "Yes" on the } \\
\text { Referendum }\end{array}$ & $\begin{array}{l}\text { Vote share of von } \\
\text { Hindenburg } \\
\text { in April } 1932\end{array}$ & $\begin{array}{l}\text { Vote share of Hitler } \\
\text { in April } 1932\end{array}$ & $\begin{array}{l}\text { Party members of } \\
\text { NSDAP in } 1933\end{array}$ \\
\hline Index of observables & -0.521 & 0.352 & -0.737 & 0.008 \\
\hline (Prediction of signal strength) & {$[0.440]$} & {$[0.462]$} & [0.453] & {$[0.007]$} \\
\hline Population, fifth polynomial & Yes & Yes & Yes & Yes \\
\hline Province fixed effects & Yes & Yes & Yes & Yes \\
\hline City ( Stadtkreis) & Yes & Yes & Yes & Yes \\
\hline Observations & 950 & 953 & 953 & 960 \\
\hline R-squared & 0.49 & 0.45 & 0.43 & 0.42 \\
\hline
\end{tabular}


Table 3. Radio Availability, Listenership, and an Increase in Nazi Vote Share

\begin{tabular}{|c|c|c|c|c|c|c|c|c|}
\hline \multirow[t]{3}{*}{ Panel A } & \multicolumn{8}{|c|}{ Change in Vote Share of the Nazi Party Since Previous Elections } \\
\hline & \multicolumn{2}{|c|}{ September 1930} & \multicolumn{2}{|c|}{ July 1932} & \multicolumn{2}{|c|}{ November 1932} & \multicolumn{2}{|c|}{ March 1933} \\
\hline & $(1)$ & $(2)$ & (3) & $(4)$ & $(5)$ & $(6)$ & $(7)$ & $(8)$ \\
\hline \multirow[t]{2}{*}{ Radio signal strength } & $-0.052^{* *}$ & $-0.051^{* *}$ & 0.016 & 0.021 & -0.008 & -0.007 & $0.041^{* *}$ & $0.045^{* *}$ \\
\hline & {$[0.024]$} & {$[0.024]$} & {$[0.037]$} & {$[0.036]$} & {$[0.012]$} & {$[0.012]$} & {$[0.018]$} & {$[0.018]$} \\
\hline \multirow[t]{2}{*}{ Share of Jewish population, 1925} & 41.095 & 40.803 & 70.317 & 74.129 & $58.368^{* *}$ & $58.591^{* *}$ & 3.117 & 5.014 \\
\hline & {$[44.560]$} & [43.288] & {$[60.527]$} & {$[60.191]$} & [22.242] & [22.648] & [45.638] & [41.603] \\
\hline \multirow[t]{2}{*}{ Share of Catholic population, 1925} & -4.448 & -4.437 & $-24.311^{* * *}$ & $-24.402^{* * *}$ & $4.307^{\star * *}$ & $4.301^{* * *}$ & 2.391 & 2.344 \\
\hline & [2.663] & [2.665] & [3.719] & [3.791] & [1.293] & [1.295] & [2.208] & {$[2.275]$} \\
\hline \multirow[t]{2}{*}{ Share of blue-collar workers, 1925} & $-5.997^{* *}$ & $-5.738^{* *}$ & $-6.737^{*}$ & -5.260 & 1.425 & 1.515 & $-4.343^{*}$ & -3.224 \\
\hline & {$[2.562]$} & {$[2.641]$} & [3.627] & [3.813] & [1.224] & [1.533] & [2.319] & {$[2.314]$} \\
\hline \multirow[t]{2}{*}{ Share of white-collar workers, 1925} & 5.368 & 5.763 & $-13.945^{\star * *}$ & $-14.327^{* * *}$ & $-4.681^{*}$ & $-4.670^{*}$ & $-8.515^{\star *}$ & $-7.281^{* *}$ \\
\hline & [4.531] & [4.503] & [3.591] & {$[4.010]$} & [2.309] & [2.496] & [3.206] & [2.996] \\
\hline \multirow[t]{2}{*}{ City ( Stadtkreis) } & 0.105 & 0.237 & $-1.825^{\star *}$ & -1.372 & -0.202 & -0.172 & -0.156 & 0.304 \\
\hline & [0.683] & {$[0.716]$} & {$[0.837]$} & {$[0.877]$} & [0.292] & {$[0.335]$} & {$[0.521]$} & {$[0.538]$} \\
\hline \multirow[t]{2}{*}{ Pogroms in 1349} & 0.187 & 0.185 & -0.822 & -0.866 & 0.270 & 0.267 & 0.237 & 0.199 \\
\hline & [0.393] & [0.394] & {$[0.855]$} & {$[0.835]$} & [0.408] & [0.402] & {$[0.328]$} & {$[0.318]$} \\
\hline \multirow[t]{2}{*}{ Jewish settlement in 1349} & 0.305 & 0.337 & 0.036 & 0.086 & -0.172 & -0.169 & $-1.020^{* * *}$ & $-0.952^{* * *}$ \\
\hline & {$[0.411]$} & [0.418] & [0.509] & {$[0.510]$} & [0.278] & {$[0.280]$} & [0.304] & [0.282] \\
\hline \multirow[t]{2}{*}{ War participants per 1,000} & 0.040 & 0.044 & -0.067 & -0.052 & 0.039 & 0.040 & -0.066 & -0.053 \\
\hline & {$[0.055]$} & {$[0.057]$} & {$[0.055]$} & {$[0.058]$} & {$[0.026]$} & {$[0.026]$} & {$[0.052]$} & {$[0.051]$} \\
\hline \multirow[t]{2}{*}{ Welfare recipients per 1,000} & -0.001 & -0.001 & -0.001 & -0.001 & -0.001 & -0.001 & $0.003^{* *}$ & $0.003^{*}$ \\
\hline & {$[0.001]$} & {$[0.001]$} & {$[0.001]$} & {$[0.001]$} & {$[0.001]$} & {$[0.000]$} & {$[0.001]$} & {$[0.001]$} \\
\hline \multirow{2}{*}{$\begin{array}{l}\text { Pensioners with social assistance per } \\
1,000\end{array}$} & -0.030 & -0.030 & 0.011 & 0.003 & -0.004 & -0.004 & $-0.053^{*}$ & $-0.052^{*}$ \\
\hline & {$[0.044]$} & {$[0.046]$} & {$[0.055]$} & {$[0.050]$} & {$[0.022]$} & {$[0.023]$} & {$[0.027]$} & {$[0.029]$} \\
\hline \multirow[t]{2}{*}{ Log of average property tax payment } & 0.132 & 0.116 & -0.354 & -0.421 & $-0.615^{\star * *}$ & $-0.619^{* * *}$ & 0.253 & 0.195 \\
\hline & [0.279] & {$[0.286]$} & {$[0.401]$} & {$[0.390]$} & [0.153] & {$[0.157]$} & {$[0.264]$} & [0.253] \\
\hline Other baseline controls & Yes & Yes & Yes & Yes & Yes & Yes & Yes & Yes \\
\hline Unemployment controls, 1933 & No & Yes & No & Yes & No & Yes & No & Yes \\
\hline Observations & 959 & 959 & 959 & 959 & 919 & 919 & 918 & 918 \\
\hline R-squared & 0.65 & 0.65 & 0.73 & 0.73 & 0.52 & 0.52 & 0.69 & 0.70 \\
\hline \multirow[t]{2}{*}{ Panel B } & \multicolumn{8}{|c|}{ Change in Vote Share of the Nazi Party Since Previous Elections (IV results) } \\
\hline & \multicolumn{2}{|c|}{ September 1930} & \multicolumn{2}{|c|}{ July 1932} & \multicolumn{2}{|c|}{ November 1932} & \multicolumn{2}{|c|}{ March 1933} \\
\hline \multirow[t]{2}{*}{ Radio subscription rate, $\%$} & $-0.287^{* * *}$ & $-0.287^{* * *}$ & 0.051 & 0.072 & -0.023 & -0.019 & $0.150^{* *}$ & $0.172^{* *}$ \\
\hline & [0.101] & {$[0.102]$} & {$[0.165]$} & {$[0.167]$} & [0.068] & [0.069] & {$[0.071]$} & {$[0.074]$} \\
\hline Baseline controls & Yes & Yes & Yes & Yes & Yes & Yes & Yes & Yes \\
\hline Unemployment controls 1933 & No & Yes & No & Yes & No & Yes & No & Yes \\
\hline Observations & 809 & 809 & 834 & 834 & 811 & 811 & 810 & 810 \\
\hline R-squared & 0.62 & 0.62 & 0.73 & 0.73 & 0.50 & 0.51 & 0.65 & 0.65 \\
\hline
\end{tabular}

Note: Standard errors clustered by province (Wahlkreis) in parentheses. ${ }^{*} p<0.1,{ }^{* *} p<0.05,{ }^{* * *} p<0.01$. Other baseline controls include voter turnout and vote shares of DNVP, NSFB, SPD, and Zentrum in 1924; fifth-order polynomial of population, and province fixed effects. Unemployment controls include share of unemployed and the share of people without full-time employment. Number of observations changes between July and November of 1932 because of redistricting. Persuasion rates are computed under a conservative assumption that there were four radio listeners per radio subscription. Because of concerns about the quality of data, we take subscription numbers from 1932 for 1933 elections. 
Table 4. Radio Availability and Voting for the Nazis: District Fixed Effects

\begin{tabular}{|c|c|c|c|c|c|c|}
\hline \multirow{3}{*}{ Sample: } & \multicolumn{6}{|c|}{ Nazi Vote Share } \\
\hline & \multicolumn{2}{|c|}{$\begin{array}{l}\text { September 1930, July } 1932, \\
\quad \text { and November } 1932\end{array}$} & \multicolumn{2}{|c|}{$\begin{array}{l}\text { All parliamentary elections } \\
1928 \text { - 1933, combined }\end{array}$} & \multicolumn{2}{|c|}{$\begin{array}{l}\text { All parliamentary elections } \\
1928-1933, \text { combined }\end{array}$} \\
\hline & $(1)$ & $(2)$ & (3) & (4) & (5) & (6) \\
\hline \multirow[t]{2}{*}{ Radio signal strength, $\mathrm{t}$} & $-0.037^{* *}$ & $-0.041^{* *}$ & & & & \\
\hline & {$[0.019]$} & {$[0.019]$} & & & & \\
\hline \multirow[t]{2}{*}{ Radio signal strength, May 1928} & & & 0.013 & 0.009 & & \\
\hline & & & {$[0.020]$} & {$[0.020]$} & & \\
\hline \multirow[t]{2}{*}{ Radio signal strength, September 1930} & & & $-0.035^{*}$ & $-0.041^{* *}$ & & \\
\hline & & & {$[0.018]$} & {$[0.019]$} & & \\
\hline \multirow[t]{2}{*}{ Radio signal strength, July 1932} & & & -0.004 & -0.005 & & \\
\hline & & & {$[0.019]$} & {$[0.019]$} & & \\
\hline \multirow[t]{2}{*}{ Radio signal strength, November 1932} & & & 0.010 & 0.010 & & \\
\hline & & & {$[0.019]$} & {$[0.019]$} & & \\
\hline \multirow[t]{2}{*}{ Radio signal strength, March 1933} & & & $0.041^{* *}$ & $0.052^{* * *}$ & & \\
\hline & & & {$[0.019]$} & {$[0.019]$} & & \\
\hline \multirow{2}{*}{$\begin{array}{l}\text { Radio signal strength, } \mathrm{t} x \text { Indicator for pro-Nazi bias } \\
\quad(0 \text { for } 1928,-1 \text { for } 1930-1932,+1 \text { for } 1933)\end{array}$} & & & & & $0.024^{\star * *}$ & $0.029 * * *$ \\
\hline & & & & & {$[0.007]$} & {$[0.007]$} \\
\hline Standard controls, interacted with time fixed effects & Yes & Yes & Yes & Yes & Yes & Yes \\
\hline District fixed effects & Yes & Yes & Yes & Yes & Yes & Yes \\
\hline Time fixed effects & Yes & Yes & Yes & Yes & Yes & Yes \\
\hline $\begin{array}{l}\text { Unemployment controls, 1933, interacted with time fixed } \\
\text { effects }\end{array}$ & No & Yes & No & Yes & No & Yes \\
\hline $\begin{array}{l}\text { p-value for test (signal strength in } 1928=a v e r a g e ~ s i g n a l \\
\text { strength in } 1930-1932)\end{array}$ & & & 0.193 & 0.223 & & \\
\hline $\begin{array}{l}\text { p-value for test (signal strength in 1933=average signal } \\
\text { strength in } 1930-1932)\end{array}$ & & & 0.000 & 0.000 & & \\
\hline Observations & 2838 & 2838 & 4716 & 4716 & 4716 & 4716 \\
\hline R-squared & 0.92 & 0.92 & 0.96 & 0.96 & 0.96 & 0.96 \\
\hline
\end{tabular}


Table 5. Radio Availability and Voting in Anti-Versailles-Treaty Referendum and April 1932 Presidential Elections.

Radio signal strength

Share of Jewish population, 1925

Share of Catholic population, 1925

Share of blue-collar workers, 1925

Share of white-collar workers, 1925

City (Stadtkreis)

Pogroms in 1349

Jewish settlement in 1349

War participants per 1,000

Welfare recipients per 1,000

Pensioners with social assistance per 1,000

Log of average property tax payment

Nazi party vote share in 1928

Referendum on the "Law against the

Enslavement of the German People"

Voted "Yes" in the Referendum (share of eligible voters)

\begin{tabular}{|c|c|c|c|c|c|c|c|}
\hline (1) & (2) & (3) & (4) & (5) & $(6)$ & (7) & $(8)$ \\
\hline$-0.078^{\star *}$ & $-0.071^{* *}$ & $-0.070^{* *}$ & $-0.062^{* *}$ & $0.058^{*}$ & $0.066^{\star \star}$ & -0.063 & -0.063 \\
\hline [0.033] & {$[0.034]$} & [0.026] & [0.026] & {$[0.030]$} & {$[0.031]$} & [0.038] & [0.039] \\
\hline-81.9 & -81.881 & -54.097 & -53.287 & -51.016 & -41.849 & 50.873 & 48.826 \\
\hline [60.961] & [62.104] & [49.779] & [50.384] & [46.393] & [47.946] & [57.606] & [57.915] \\
\hline$-12.546^{\star * \star}$ & $-12.569^{* * *}$ & $-9.596^{\star *}$ & $-9.640^{* *}$ & $30.278^{\star * *}$ & $30.059^{* * *}$ & $-27.998^{* * *}$ & $-27.924^{* * *}$ \\
\hline [3.395] & [3.311] & [3.706] & [3.619] & [2.732] & [2.660] & [2.612] & [2.606] \\
\hline-3.198 & -1.71 & -2.554 & -0.96 & $-12.255^{\star * *}$ & $-9.358^{* *}$ & $-9.380^{* *}$ & $-9.339^{* *}$ \\
\hline [3.743] & [3.575] & [3.508] & [3.298] & [3.651] & [3.512] & [3.553] & [3.771] \\
\hline$-21.476^{\star * *}$ & $-20.704^{* \star *}$ & $-24.069^{* \star *}$ & $-23.633^{\star * *}$ & $21.283^{\star \star \star}$ & $19.430^{\star *}$ & $-18.729^{* \star}$ & $-17.542^{\star *}$ \\
\hline [7.158] & [7.180] & [7.023] & [6.887] & [7.112] & [7.308] & [7.055] & [7.419] \\
\hline-1.034 & -0.349 & -1.062 & -0.367 & $-1.956^{*}$ & -1.120 & -0.151 & -0.021 \\
\hline [1.249] & [1.190] & [1.124] & [1.134] & [1.055] & [0.928] & [0.990] & [0.916] \\
\hline-0.223 & -0.235 & -0.609 & -0.628 & 0.077 & -0.017 & -0.206 & -0.193 \\
\hline [0.950] & [0.948] & [0.962] & [0.962] & [0.730] & [0.733] & [0.777] & [0.783] \\
\hline 0.611 & 0.746 & 0.841 & $0.968^{*}$ & 0.077 & 0.133 & 0.086 & 0.137 \\
\hline [0.564] & [0.572] & [0.512] & [0.513] & [0.743] & [0.778] & [0.774] & [0.793] \\
\hline 0.038 & 0.055 & 0.021 & 0.039 & -0.039 & -0.011 & -0.026 & -0.023 \\
\hline [0.091] & [0.087] & [0.080] & [0.078] & [0.078] & {$[0.076]$} & [0.080] & {$[0.077]$} \\
\hline$-0.009^{\star * *}$ & $-0.009^{\star * *}$ & $-0.009^{\star * *}$ & $-0.009^{* * *}$ & 0.001 & 0.000 & $-0.003^{\star * *}$ & $-0.003^{* * *}$ \\
\hline$[0.001]$ & [0.001] & [0.001] & [0.001] & [0.001] & [0.001] & [0.001] & [0.001] \\
\hline-0.09 & -0.09 & $-0.098^{*}$ & $-0.100^{*}$ & 0.024 & 0.005 & -0.053 & -0.048 \\
\hline [0.059] & [0.059] & [0.057] & [0.057] & {$[0.066]$} & [0.064] & [0.058] & [0.057] \\
\hline $0.962^{*}$ & 0.865 & 0.785 & 0.687 & $0.885^{\star \star *}$ & $0.754^{* *}$ & $-0.447^{*}$ & $-0.469^{*}$ \\
\hline \multirow[t]{3}{*}{ [0.528] } & [0.512] & [0.496] & [0.482] & [0.281] & [0.284] & [0.233] & [0.248] \\
\hline & & $0.644^{* * *}$ & $0.645^{\star \star *}$ & & & & \\
\hline & & [0.092] & [0.090] & & & & \\
\hline Yes & Yes & Yes & Yes & Yes & Yes & Yes & Yes \\
\hline Yes & Yes & Yes & Yes & Yes & Yes & Yes & Yes \\
\hline Yes & Yes & Yes & Yes & Yes & Yes & Yes & Yes \\
\hline No & Yes & No & Yes & No & Yes & No & Yes \\
\hline 950 & 950 & 950 & 950 & 953 & 953 & 953 & 953 \\
\hline 0.83 & 0.83 & 0.84 & 0.85 & 0.87 & 0.87 & 0.86 & 0.86 \\
\hline
\end{tabular}

Population, fifth-order polynomia

Voting controls, 1924

Province fixed effects

Unemployment controls, 1933

Observations

R-squared

0.83

April 1932 Presidential Elections

.

SPD, and Zentrum in 1924. Unemployment controls include share of unemployed and the share of people without full-time employment. 
Table 6. Radio Availability and Nazi Party Membership: Cross-Sectional Estimates

\begin{tabular}{|c|c|c|c|c|c|c|}
\hline & \multicolumn{6}{|c|}{ Log of the Number of New Party Members of NSDAP } \\
\hline & \multicolumn{2}{|c|}{ January 1932-January 1933} & \multicolumn{4}{|c|}{ February-May 1933} \\
\hline & (1) & (2) & (3) & $(4)$ & (5) & $(6)$ \\
\hline Radio signal strength & $\begin{array}{c}0.003 \\
{[0.002]}\end{array}$ & $\begin{array}{c}0.004 \\
{[0.002]}\end{array}$ & $\begin{array}{c}0.005^{\star * *} \\
{[0.002]}\end{array}$ & $\begin{array}{l}0.005^{\star *} \\
{[0.002]}\end{array}$ & $\begin{array}{l}0.005^{* *} \\
{[0.002]}\end{array}$ & $\begin{array}{l}0.005^{* *} \\
{[0.002]}\end{array}$ \\
\hline Share of Jewish population, 1925 & $\begin{array}{l}-6.501 \\
{[5.510]}\end{array}$ & $\begin{array}{l}-6.072 \\
{[5.671]}\end{array}$ & $\begin{array}{l}7.865^{\star} \\
{[4.575]}\end{array}$ & $\begin{array}{c}7.008 \\
{[4.326]}\end{array}$ & $\begin{array}{l}8.137^{*} \\
{[4.460]}\end{array}$ & $\begin{array}{l}7.316^{*} \\
{[4.174]}\end{array}$ \\
\hline Share of Catholic population, 1925 & $\begin{array}{l}-0.404^{*} \\
{[0.236]}\end{array}$ & $\begin{array}{l}-0.428^{*} \\
{[0.237]}\end{array}$ & $\begin{array}{c}0.022 \\
{[0.143]}\end{array}$ & $\begin{array}{c}0.041 \\
{[0.141]}\end{array}$ & $\begin{array}{c}0.039 \\
{[0.142]}\end{array}$ & $\begin{array}{c}0.063 \\
{[0.138]}\end{array}$ \\
\hline Share of blue-collar workers, 1925 & $\begin{array}{c}-0.697^{* *} \\
{[0.327]}\end{array}$ & $\begin{array}{l}-0.558 \\
{[0.350]}\end{array}$ & $\begin{array}{l}-0.326 \\
{[0.214]}\end{array}$ & $\begin{array}{c}-0.512^{* *} \\
{[0.226]}\end{array}$ & $\begin{array}{l}-0.297 \\
{[0.217]}\end{array}$ & $\begin{array}{c}-0.483^{* *} \\
{[0.228]}\end{array}$ \\
\hline Share of white-collar workers, 1925 & $\begin{array}{c}2.291^{* * *} \\
{[0.649]}\end{array}$ & $\begin{array}{c}2.638^{* * *} \\
{[0.661]}\end{array}$ & $\begin{array}{c}0.175 \\
{[0.513]}\end{array}$ & $\begin{array}{c}0.084 \\
{[0.521]}\end{array}$ & $\begin{array}{c}0.078 \\
{[0.516]}\end{array}$ & $\begin{array}{l}-0.051 \\
{[0.525]}\end{array}$ \\
\hline City ( Stadtkreis) & $\begin{array}{l}-0.129 \\
{[0.109]}\end{array}$ & $\begin{array}{l}-0.065 \\
{[0.115]}\end{array}$ & $\begin{array}{c}-0.177^{* *} \\
{[0.073]}\end{array}$ & $\begin{array}{c}-0.228^{* * *} \\
{[0.077]}\end{array}$ & $\begin{array}{c}-0.172^{* *} \\
{[0.072]}\end{array}$ & $\begin{array}{c}-0.225^{\star * *} \\
{[0.076]}\end{array}$ \\
\hline Pogroms in 1349 & $\begin{array}{l}-0.070 \\
{[0.077]}\end{array}$ & $\begin{array}{l}-0.067 \\
{[0.075]}\end{array}$ & $\begin{array}{l}-0.056 \\
{[0.055]}\end{array}$ & $\begin{array}{l}-0.059 \\
{[0.055]}\end{array}$ & $\begin{array}{l}-0.053 \\
{[0.055]}\end{array}$ & $\begin{array}{l}-0.056 \\
{[0.055]}\end{array}$ \\
\hline Jewish settlement in 1349 & $\begin{array}{l}-0.059 \\
{[0.068]}\end{array}$ & $\begin{array}{l}-0.046 \\
{[0.066]}\end{array}$ & $\begin{array}{c}0.042 \\
{[0.063]}\end{array}$ & $\begin{array}{c}0.038 \\
{[0.063]}\end{array}$ & $\begin{array}{c}0.045 \\
{[0.063]}\end{array}$ & $\begin{array}{c}0.041 \\
{[0.063]}\end{array}$ \\
\hline War participants per 1,000 & $\begin{array}{l}-0.001 \\
{[0.011]}\end{array}$ & $\begin{array}{l}-0.001 \\
{[0.011]}\end{array}$ & $\begin{array}{l}-0.001 \\
{[0.016]}\end{array}$ & $\begin{array}{l}-0.001 \\
{[0.016]}\end{array}$ & $\begin{array}{l}-0.001 \\
{[0.016]}\end{array}$ & $\begin{array}{l}-0.001 \\
{[0.016]}\end{array}$ \\
\hline Welfare recipients per 1,000 & $\begin{array}{c}0.000 \\
{[0.000]}\end{array}$ & $\begin{array}{c}0.000 \\
{[0.000]}\end{array}$ & $\begin{array}{c}0.000 \\
{[0.000]}\end{array}$ & $\begin{array}{l}-0.000^{*} \\
{[0.000]}\end{array}$ & $\begin{array}{c}0.000 \\
{[0.000]}\end{array}$ & $\begin{array}{l}-0.000^{*} \\
{[0.000]}\end{array}$ \\
\hline Pensioners with social assistance per 1,000 & $\begin{array}{c}0.011 \\
{[0.007]}\end{array}$ & $\begin{array}{l}0.013^{*} \\
{[0.007]}\end{array}$ & $\begin{array}{c}0.005 \\
{[0.004]}\end{array}$ & $\begin{array}{c}0.005 \\
{[0.004]}\end{array}$ & $\begin{array}{c}0.005 \\
{[0.004]}\end{array}$ & $\begin{array}{c}0.004 \\
{[0.004]}\end{array}$ \\
\hline Lof of average property tax payment & $\begin{array}{c}0.002 \\
{[0.048]}\end{array}$ & $\begin{array}{l}-0.009 \\
{[0.049]}\end{array}$ & $\begin{array}{c}0.001 \\
{[0.036]}\end{array}$ & $\begin{array}{c}0.013 \\
{[0.035]}\end{array}$ & $\begin{array}{c}0.001 \\
{[0.036]}\end{array}$ & $\begin{array}{c}0.013 \\
{[0.034]}\end{array}$ \\
\hline Log of new party membership in 01/1932-01/1933 & & & & & $\begin{array}{c}0.043 \\
{[0.030]}\end{array}$ & $\begin{array}{l}0.051^{*} \\
{[0.029]}\end{array}$ \\
\hline $\begin{array}{l}\text { Population, fifth-order polynomial } \\
\text { Voting controls, } 1924\end{array}$ & $\begin{array}{l}\text { Yes } \\
\text { Yes }\end{array}$ & $\begin{array}{l}\text { Yes } \\
\text { Yes }\end{array}$ & $\begin{array}{l}\text { Yes } \\
\text { Yes }\end{array}$ & $\begin{array}{l}\text { Yes } \\
\text { Yes }\end{array}$ & $\begin{array}{l}\text { Yes } \\
\text { Yes }\end{array}$ & $\begin{array}{l}\text { Yes } \\
\text { Yes }\end{array}$ \\
\hline Province fixed effects & Yes & Yes & Yes & Yes & Yes & Yes \\
\hline Unemployment controls, 1933 & No & Yes & No & Yes & No & Yes \\
\hline Observations & 613 & 613 & 613 & 613 & 613 & 613 \\
\hline R-squared & 0.67 & 0.67 & 0.34 & 0.35 & 0.34 & 0.35 \\
\hline
\end{tabular}

NSFB, SPD, and Zentrum in 1924. Unemployment controls include share of unemployed and the share of people without full-time employment. 
Table 7. Radio Availability and Anti-Semitism

\begin{tabular}{|c|c|c|c|}
\hline & Letters to Der Stürmer & $\begin{array}{l}\text { Log(deportations } \\
\text { before 1942) }\end{array}$ & $\begin{array}{l}\text { Attacks on } \\
\text { synagogues }\end{array}$ \\
\hline & $(1)$ & $(2)$ & (3) \\
\hline \multirow[t]{2}{*}{ Radio signal strength in 1935} & $0.008^{\star *}$ & $0.017^{\star *}$ & 0.001 \\
\hline & {$[0.003]$} & {$[0.007]$} & [0.002] \\
\hline \multirow[t]{2}{*}{ Log (population) } & $0.178^{* * *}$ & $0.289^{* * *}$ & -0.007 \\
\hline & {$[0.029]$} & [0.073] & {$[0.015]$} \\
\hline \multirow[t]{2}{*}{ Share of Jewish population, 1925} & $10.846^{* * *}$ & $42.423^{* * *}$ & $4.453^{* * *}$ \\
\hline & [2.166] & [3.222] & {$[0.686]$} \\
\hline \multirow[t]{2}{*}{ Share of Catholic population, 1925} & -0.033 & $0.458^{* * *}$ & -0.032 \\
\hline & {$[0.086]$} & {$[0.155]$} & {$[0.072]$} \\
\hline \multirow[t]{2}{*}{ Share of blue-collar workers, 1925} & $-0.031^{* * *}$ & $-0.113^{* * *}$ & $-0.017^{* * *}$ \\
\hline & [0.008] & [0.019] & [0.005] \\
\hline \multirow[t]{2}{*}{ Share of white-collar workers, 1925} & $0.032^{*}$ & $0.154^{* * *}$ & $0.039^{* * *}$ \\
\hline & {$[0.017]$} & {$[0.041]$} & {$[0.010]$} \\
\hline \multirow[t]{2}{*}{ Pogroms in 1349} & $0.363^{* * *}$ & $0.773^{* * *}$ & $0.155^{\star *}$ \\
\hline & {$[0.076]$} & {$[0.130]$} & [0.058] \\
\hline \multirow[t]{2}{*}{ Jewish settlement in 1349} & $0.146^{*}$ & $0.204^{*}$ & -0.032 \\
\hline & [0.082] & [0.111] & [0.058] \\
\hline \multirow[t]{2}{*}{ War participants per 1,000} & -0.004 & -0.028 & 0.004 \\
\hline & [0.018] & {$[0.037]$} & {$[0.007]$} \\
\hline \multirow[t]{2}{*}{ Welfare recipients per 1,000} & 0.000 & 0.001 & $-0.001^{* * *}$ \\
\hline & {$[0.000]$} & {$[0.001]$} & {$[0.000]$} \\
\hline \multirow[t]{2}{*}{ Pensioners with social assistance per 1,000} & $0.009^{* *}$ & $0.041^{* *}$ & 0.002 \\
\hline & {$[0.004]$} & {$[0.016]$} & {$[0.004]$} \\
\hline \multirow[t]{2}{*}{ Log of average property tax payment } & $0.188^{* * *}$ & $0.189^{\star * *}$ & -0.004 \\
\hline & {$[0.037]$} & {$[0.059]$} & {$[0.018]$} \\
\hline Voting controls, 1924 & Yes & Yes & Yes \\
\hline Province fixed effects & Yes & Yes & Yes \\
\hline Observations & 1217 & 1157 & 989 \\
\hline R-squared & 0.40 & 0.44 & 0.12 \\
\hline
\end{tabular}


Table 8. Radio Availability and Anti-Semitism, the Role of Historic Predispositions

\begin{tabular}{|c|c|c|c|}
\hline & $\begin{array}{l}\text { Letters to Der } \\
\text { Stürmer } \\
\text { (1) }\end{array}$ & $\begin{array}{l}\text { Log(deportations } \\
\text { before 1942) } \\
\qquad(2)\end{array}$ & $\begin{array}{l}\text { Attacks on } \\
\text { synagogues } \\
(3)\end{array}$ \\
\hline \multirow[t]{2}{*}{ Pogroms in $1349{ }^{*}$ Radio signal strength } & $0.031^{* * *}$ & $0.047^{* *}$ & 0.007 \\
\hline & {$[0.006]$} & {$[0.018]$} & [0.005] \\
\hline \multirow[t]{2}{*}{ Radio signal strength (1935) } & $-0.020^{* * *}$ & $-0.035^{*}$ & -0.007 \\
\hline & {$[0.006]$} & {$[0.018]$} & {$[0.006]$} \\
\hline \multirow[t]{2}{*}{ Log (population) } & $0.272^{* * *}$ & $0.505^{\star * *}$ & -0.009 \\
\hline & {$[0.059]$} & {$[0.118]$} & {$[0.017]$} \\
\hline \multirow[t]{2}{*}{ Share of Jewish population, 1925} & $14.174^{* * *}$ & $50.479^{* * *}$ & 2.438 \\
\hline & [3.759] & [10.096] & [1.561] \\
\hline \multirow[t]{2}{*}{ Share of Catholic population, 1925} & -0.002 & 0.629 & -0.154 \\
\hline & [0.183] & [0.390] & {$[0.152]$} \\
\hline \multirow[t]{2}{*}{ Share of blue-collar workers, 1925} & $-0.079^{* * *}$ & $-0.174^{* * *}$ & -0.007 \\
\hline & {$[0.028]$} & [0.040] & [0.009] \\
\hline \multirow[t]{2}{*}{ Share of white-collar workers, 1925} & $0.088^{*}$ & $0.188^{* *}$ & 0.019 \\
\hline & [0.048] & {$[0.074]$} & [0.015] \\
\hline \multirow[t]{2}{*}{ Pogroms in 1349} & $-0.426^{\star *}$ & -0.511 & -0.017 \\
\hline & {$[0.177]$} & {$[0.512]$} & {$[0.115]$} \\
\hline \multirow[t]{2}{*}{ War participants per 1,000} & 0.009 & -0.008 & 0.001 \\
\hline & [0.025] & [0.043] & {$[0.006]$} \\
\hline \multirow[t]{2}{*}{ Welfare recipients per 1,000} & 0.000 & 0.000 & 0.000 \\
\hline & {$[0.000]$} & {$[0.000]$} & {$[0.000]$} \\
\hline \multirow[t]{2}{*}{ Pensioners with social assistance per 1,000} & 0.021 & $0.055^{\star *}$ & 0.000 \\
\hline & {$[0.016]$} & {$[0.022]$} & [0.003] \\
\hline \multirow[t]{2}{*}{ Log of average property tax payment } & $0.206^{* * *}$ & $0.358^{* * *}$ & 0.014 \\
\hline & {$[0.064]$} & {$[0.104]$} & {$[0.022]$} \\
\hline Voting controls, 1924 & Yes & Yes & Yes \\
\hline Province fixed effects & Yes & Yes & Yes \\
\hline Observations & 308 & 286 & 265 \\
\hline R-squared & 0.55 & 0.57 & 0.23 \\
\hline \multicolumn{4}{|c|}{$\begin{array}{l}\text { Note: Standard errors are clustered by province (Wahlkreis). }{ }^{*} p<0.1,{ }^{* *} p<0.05,{ }^{* * *} p<0.01 \text {. Unit of observation is city in } \\
\text { Voigtländer and Voth }(2012) \text { sample. Sample include only cities with jewish settlements in } 1349 \text {. Voting controls include } \\
\text { voter turnout and vote shares of DNVP, NSFB, SPD, and Zentrum in } 1924 \text {. The results are qualitatively similar if we use } \\
\text { only the set of controls of Voigtländer and Voth (2012), i.e., the share of Jews, share of Catholics, population, and pogroms } \\
\text { in } 1349 .\end{array}$} \\
\hline
\end{tabular}


Table 9. Placebo Tests

\begin{tabular}{|c|c|c|c|c|c|}
\hline \multicolumn{6}{|c|}{ Panel A: Radio Availability in 1928 and Change in Vote Share of the Nazi Party Since Previous Elections } \\
\hline Dependent Variables: & $\begin{array}{c}\text { Radio Signal } \\
\text { Strength in } 1930\end{array}$ & $\begin{array}{l}\text { Baseline } \\
\text { Controls }\end{array}$ & $\begin{array}{l}\text { Unemployment } \\
\text { Controls }\end{array}$ & Obs. & R-squared \\
\hline $\begin{array}{l}\text { Change between Votes for Nazi Party in May } \\
1928 \text { and vote for DNVP in December } 1924\end{array}$ & $\begin{array}{l}-0.009 \\
{[0.082]}\end{array}$ & Yes & Yes & 959 & 0.77 \\
\hline $\begin{array}{l}\text { Change between Votes for Nazi Party in May } \\
1928 \text { and vote for NSBF in December } 1924\end{array}$ & $\begin{array}{c}0.006 \\
{[0.018]} \\
\end{array}$ & Yes & Yes & 959 & 0.42 \\
\hline \multicolumn{6}{|c|}{ Panel B: Radio Availability in 1930 and Voting in 1924} \\
\hline Dependent Variables: & $\begin{array}{c}\text { Radio Signal } \\
\text { Strength in } 1930\end{array}$ & $\begin{array}{l}\text { Baseline } \\
\text { Controls }\end{array}$ & $\begin{array}{l}\text { Unemployment } \\
\text { Controls }\end{array}$ & Obs. & R-squared \\
\hline Vote share of DNVP in 1924 & $\begin{array}{l}-0.00073 \\
{[0.00048]}\end{array}$ & Yes & Yes & 896 & 0.86 \\
\hline Vote share of KPD in 1924 & $\begin{array}{l}-0.00005 \\
{[0.00019]}\end{array}$ & Yes & Yes & 896 & 0.70 \\
\hline Vote share of SPD in 1924 & $\begin{array}{l}-0.00013 \\
{[0.00028]}\end{array}$ & Yes & Yes & 896 & 0.86 \\
\hline Vote share of Zentrum in 1924 & $\begin{array}{l}-0.00014 \\
{[0.00016]}\end{array}$ & Yes & Yes & 896 & 0.99 \\
\hline Voter turnout in 1924 & $\begin{array}{c}-0.00322 \\
{[0.01931]}\end{array}$ & Yes & Yes & 896 & 0.73 \\
\hline \multicolumn{6}{|c|}{ Panel C: Radio Availability in 1930 and Voting in 1920} \\
\hline Dependent Variables: & $\begin{array}{c}\text { Radio Signal } \\
\text { Strength in } 1930\end{array}$ & $\begin{array}{l}\text { Baseline } \\
\text { Controls }\end{array}$ & $\begin{array}{l}\text { Unemployment } \\
\text { Controls }\end{array}$ & Obs. & R-squared \\
\hline Vote share of DNVP in 1920 & $\begin{array}{c}0.00082^{*} \\
{[0.00045]}\end{array}$ & Yes & Yes & 896 & 0.84 \\
\hline Vote share of KPD in 1920 & $\begin{array}{c}0.00002 \\
{[0.00016]}\end{array}$ & Yes & Yes & 896 & 0.43 \\
\hline Vote share of SPD in 1920 & $\begin{array}{c}0.00046 \\
{[0.00046]}\end{array}$ & Yes & Yes & 896 & 0.79 \\
\hline Vote share of Zentrum in 1920 & $\begin{array}{c}0.0001 \\
{[0.00013]}\end{array}$ & Yes & Yes & 896 & 0.99 \\
\hline Voter turnout in 1920 & $\begin{array}{c}0.00008 \\
{[0.00021]} \\
\end{array}$ & Yes & Yes & 896 & 0.79 \\
\hline \multicolumn{6}{|c|}{ Panel D: Radio Availability in 1930 and Voting in 1925 Presidential Elections } \\
\hline Dependent Variables: & $\begin{array}{c}\text { Radio Signal } \\
\text { Strength in } 1930 \\
\end{array}$ & $\begin{array}{l}\text { Baseline } \\
\text { Controls } \\
\end{array}$ & $\begin{array}{l}\text { Unemployment } \\
\text { Controls }\end{array}$ & Obs. & R-squared \\
\hline Vote share of von Hindenburg in 1925 & $\begin{array}{l}0.0010 \\
{[0.027]}\end{array}$ & Yes & Yes & 954 & 0.84 \\
\hline Vote share of Marx in 1925 & $\begin{array}{l}-0.0040 \\
{[0.024]}\end{array}$ & Yes & Yes & 954 & 0.88 \\
\hline Vote share of Thälmann in 1925 & $\begin{array}{l}0.0030 \\
{[0.017]}\end{array}$ & Yes & Yes & 954 & 0.40 \\
\hline Voter turnout in 1925 & $\begin{array}{r}-0.0020 \\
{[0.019]} \\
\end{array}$ & Yes & Yes & 954 & 0.71 \\
\hline \multicolumn{6}{|c|}{ Panel E: Radio Availability in 1935 and City-Level Violence Before 1930s } \\
\hline Dependent Variables: & $\begin{array}{c}\text { Radio Signal } \\
\text { Strength in } 1935 \\
\end{array}$ & $\begin{array}{l}\text { Baseline } \\
\text { Controls } \\
\end{array}$ & $\begin{array}{c}\text { Unemployment } \\
\text { Controls }\end{array}$ & Obs. & R-squared \\
\hline Crime rate, $1900-1920$ & $\begin{array}{l}-0.0001 \\
{[0.0002]}\end{array}$ & Yes & $\frac{\text { All cities }}{\text { Yes }}$ & 1142 & 0.43 \\
\hline Pogroms in 1920 s & $\begin{array}{c}0.0007 \\
{[0.0012]}\end{array}$ & Yes & Yes & 1194 & 0.15 \\
\hline & Only & cities with & Jewish settlements & in $134 \mathrm{c}$ & \\
\hline Crime rate, $1900-1920$ & $\begin{array}{l}-0.0003 \\
{[0.0003]}\end{array}$ & Yes & Yes & 301 & 0.45 \\
\hline Pogroms in 1920s & $\begin{array}{c}0.0028 \\
{[0.0024]}\end{array}$ & Yes & Yes & 303 & 0.24 \\
\hline
\end{tabular}

Note: Each line reports results of a separate regression. Specifications are exactly the same as in corresponding regressions with real rather than placebo outcomes, except for Panel A, where the list of baseline controls does not include the vote for DNVP and NSBF in 1924. In Panel B voting controls are for turnout and vote for DNVP, SPD, KPD, and Zentrum in 1920 (NSFB did not participate in 1920 elections). Results are the same if we do not include unemployment controls. 


\section{Appendix}

\section{Data sources}

Data on transmitters: Rundfunk Jahrbuch 1929, 1929, Sept 1930 - Mitteilungen der Reichs-RundfunkGesellschaft, 211, 1930, April 1932 - Mitteilungen der Reichs-Rundfunk-Gesellschaft, 303, 1932, October 1932 - Mitteilungen der Reichs-Rundfunk-Gesellschaft, 330, 1932, March 1933 - Mitteilungen der Reichs-Rundfunk-Gesellschaft, 351, 1933, and others till 1938. All those sources cite as a primary source "Union Internationale de telecommunications." - Brundjak, Andreas (2010) Die Geschichte der deutschen Mittelwellen-Sendeanlagen von 1923 bis 1945. Funk Verlag Bernhard Hein e.K., Table p. 109ff. Signal strength has been calculated using Irregular Terrain Model (Hufford 2002, Olken 2008)

Electoral and sociodemographic data: "Wahl- und Sozialdaten der Gemeinden und Kreise des Deutschen Reiches 1920 - 1933” (ZA study number 8013). Principal investigator: J.W. Falter; available through the Zentralarchiv für empirische Sozialforschung in Köln, Germany, (March/April 1988).

Data on listeners: "Teilnahme am Rundfunk in den einzelnen OPD-Bezirken in Orten mit mehr als 2500 Einwohnern am 1. April 1933," Veröffentlichungen des Verbandes der Funkindustrie e.V., 12, 1933. We use data from the appendix: the number of registered listeners (paying a radio license fee or exempt from paying) divided by the number of households for the years 1931, 1932, and 1933 Mitteilungen der Reichsrundfunkgesellschaft, various numbers from the end of 1933 and beginning of 1934.

Data on deportations: Gedenkbuch, Bundesarchiv.

Letters to Der Stürmer, pogroms in 1349, and attacks on synagogues: Voigtländer and Voth (2012).

Hitler's electoral speeches: Domarus, Max (1962) "Hitler Reden und Proklamationen 1932 - 1945", Band 1, Würzburg, p. 115ff., p. 139ff.

Data on woodland: "Ergebnisse der Forstwirtschaftlichen Erhebung," Statistik des Deutschen Reichs, Band 386 (1927).

Data on welfare: "Die öffentliche Fürsorge im Deutschen Reich in den Rechnungsjahren 1927 bis 1931," Statistik des Deutschen Reichs, Band 421, Berlin, 1933, Verlag Hobbing. We use data from Statistik der Bezirksfürsorgeverbände. Einzelergebnisse, Tabelle 5. Gesamter Personenkreis der unterstützten Hilfsbedürftigen und Fürsorgekosten im Rechnungsjahr 1929, Spalten: Einwohnerzahl in 
1000, 3- Auf 1000 Einwohner, 4- Kriegsbeschädigte, Kriegshinterbliebene und Gleichgestellt, 5Sozialrentner, 6- Kleinrentner und Gleichgestellte, S. 114-135

Data on income tax: "Die Einkommen- und Körperschaftssteuerveranlagungen für 1932 und 1933," Statistik des Deutschen Reichs, Band 482, Berlin, 1936, Verlag für Sozialpolitik, Wirtschaft und Statistik. We use data from Teil I Abschnitt A, Einkommensteuerveranlagung, Steuerpflichtige, Einkünfte und festgesetzte Steuer 1932 und 1933, S. 62 - 93.

Data on corporate tax: "Die Einkommen- und Körperschaftssteuerveranlagungen für 1932 und 1933," Statistik des Deutschen Reichs, Band 482, Berlin 1936, Verlag für Sozialpolitik, Wirtschaft und Statistik. We use data from Teil II Abschnitt A, Körperschaftsteuerveranlagung, S. 302 - 310.

Data on property tax: "Die Hauptveranlagung der Vermögensteuer nach dem Stand vom 1 Januar 1935," Statistik des Deutschen Reichs, Band 519, Berlin, 1938, Verlag für Sozialpolitik, Wirtschaft und Statistik. We use data from Anhang, Abschnitt A, Vermögensteuerveranlagung 1931, S. 194 - 209

Data on NSDAP Party membership: Project by Prof. Falter: "NSDAP-Members in Germany Who Joined the Party in the Years Before 1933 - 1934". The samples were taken at random by members of the Arbeitsbereich Vergleichende Faschismusforschung des ZI6 der FU Berlin, in cooperation with the Department of Sociology, University of Minnesota, Minneapolis. Sample description: Historical Social Research, Vol. 16, 1991, No. 3, 113 - 151. We use only 1932 and 1933 data. 
Figure A1. Radio Signal Strength in Germany. Raw signal strength measure.

A. May 1928

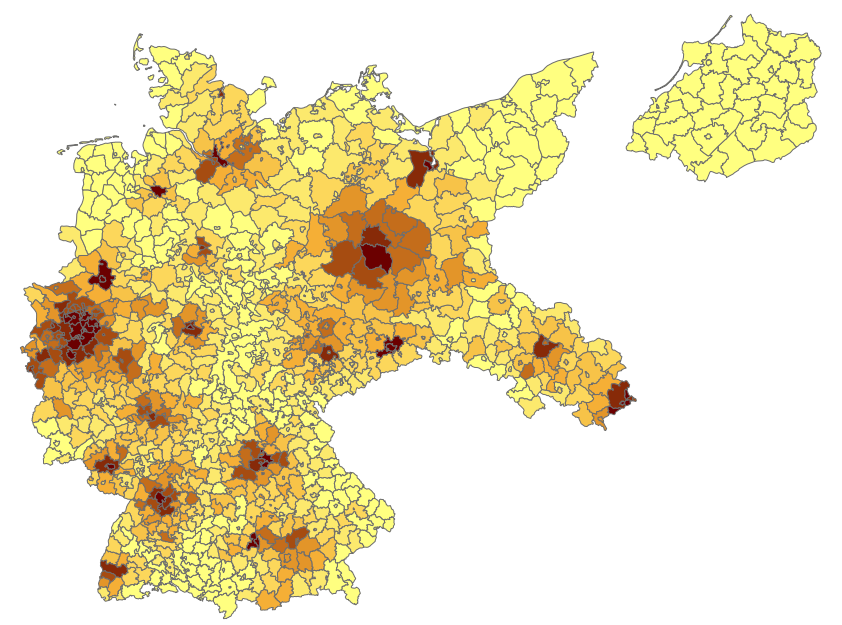

B. July 1932

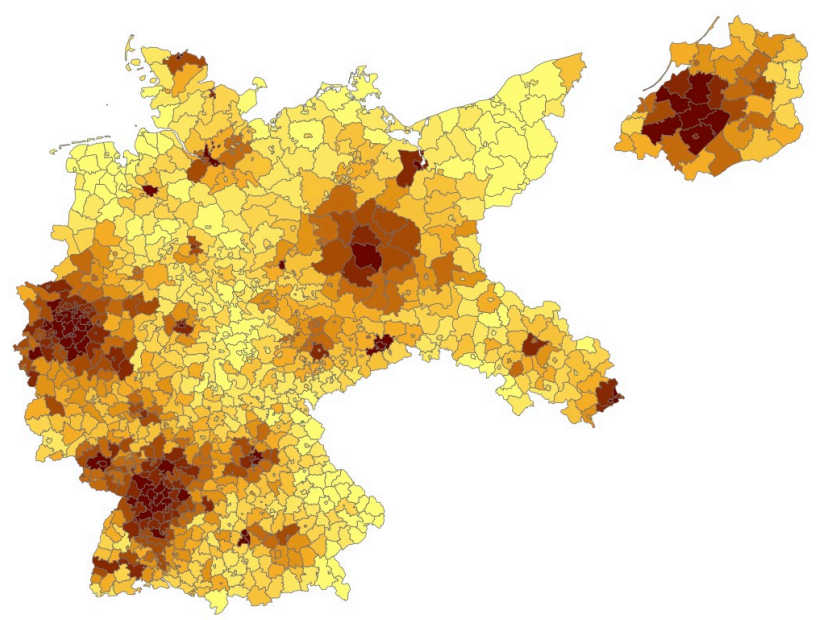

B. September 1930

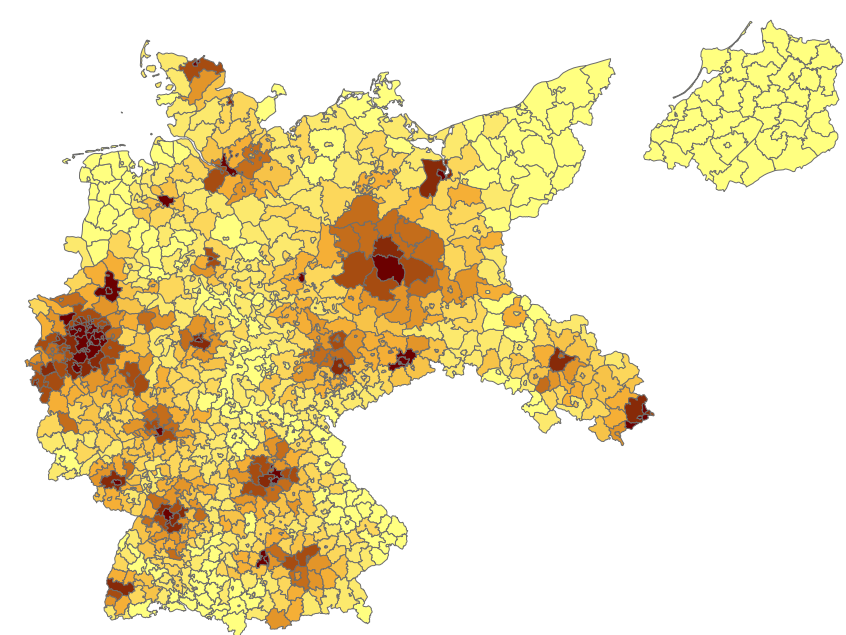

D. March 1933

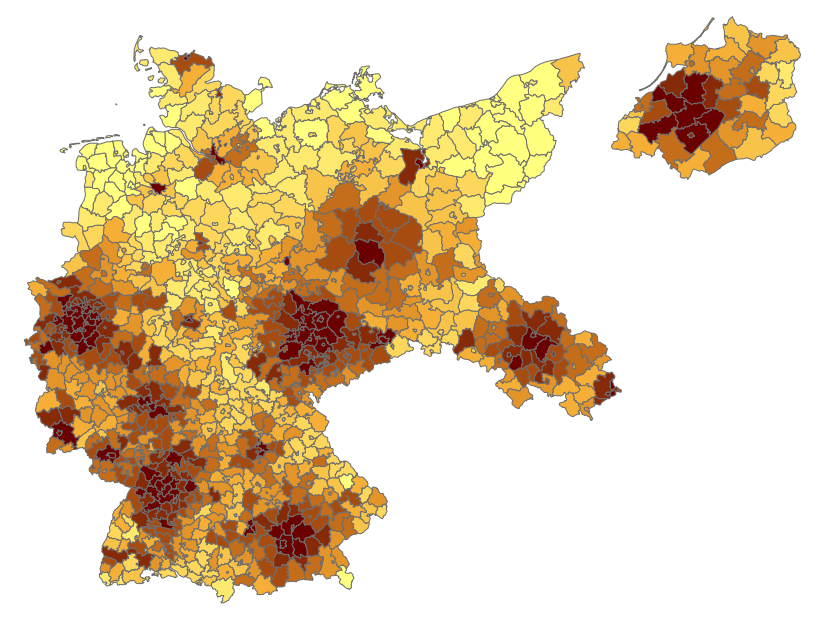


Figure A2. Changes in Nazi vote share: Residual plots

September 1930

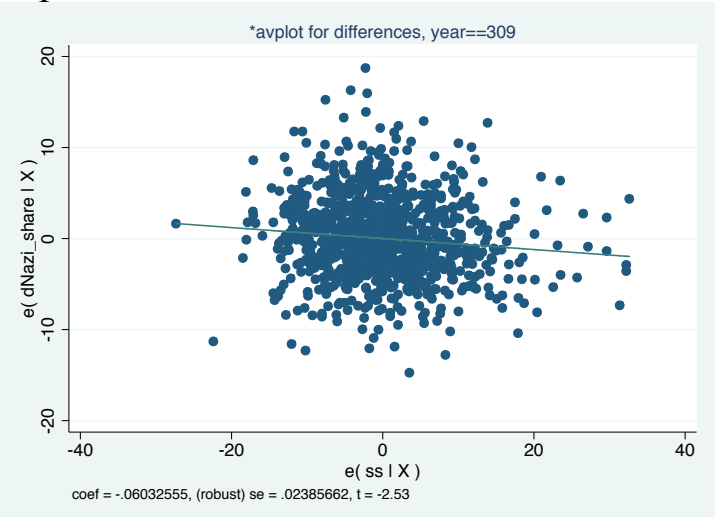

November 1932

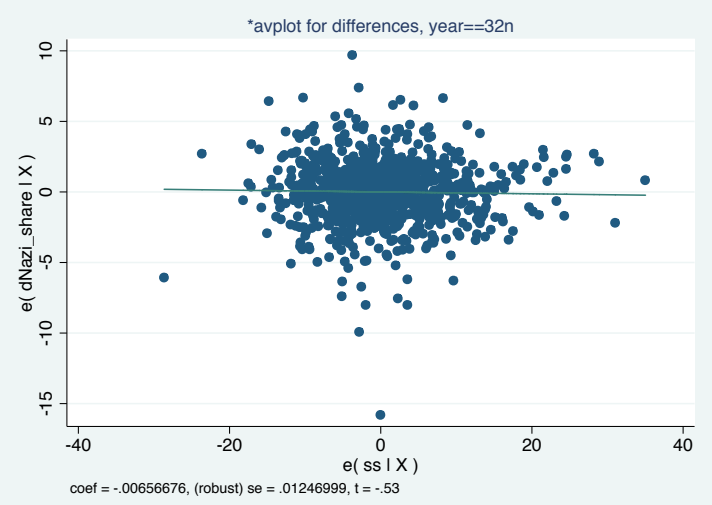

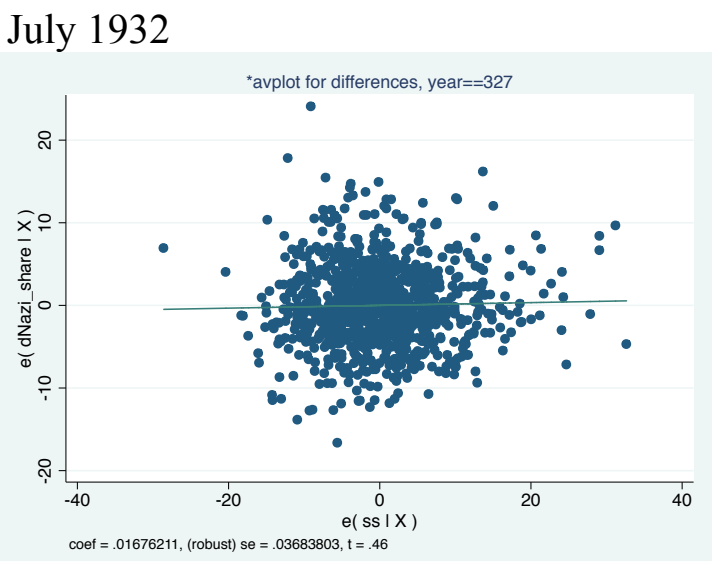

March 1933

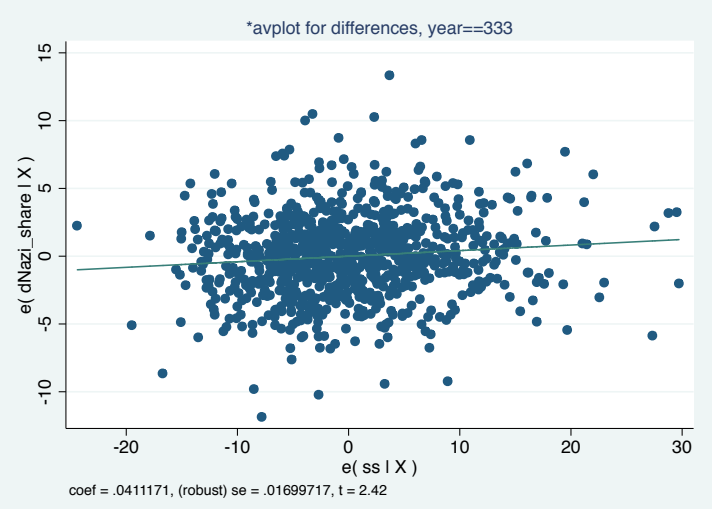


Figure A3.The change in Nazi party vote share, actual and predicted for signal strength set to a sample minimum. Kernel density estimates. Blue lines - raw data, red lines - prediction for the case of minimal signal strength.

September 1930
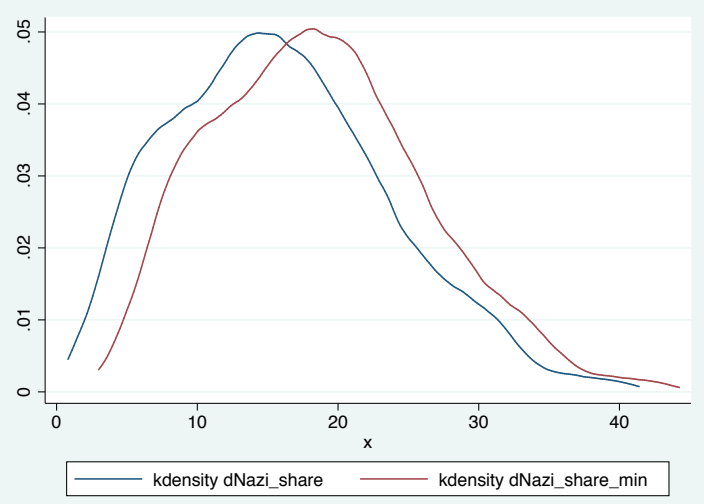

\section{November 1932}

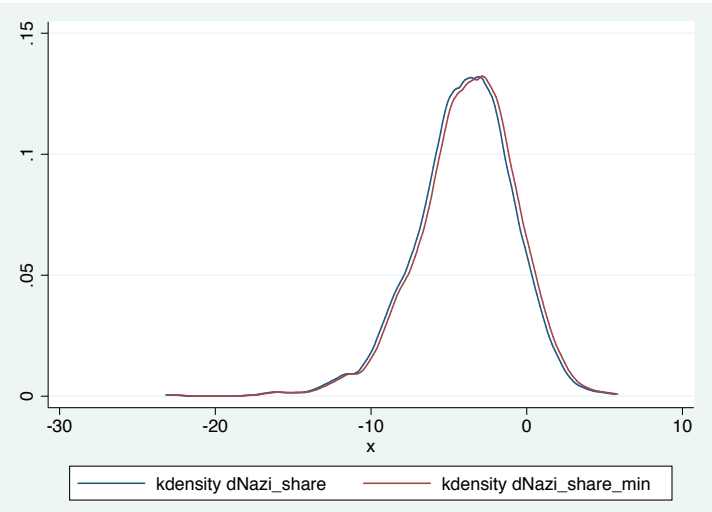

July 1932

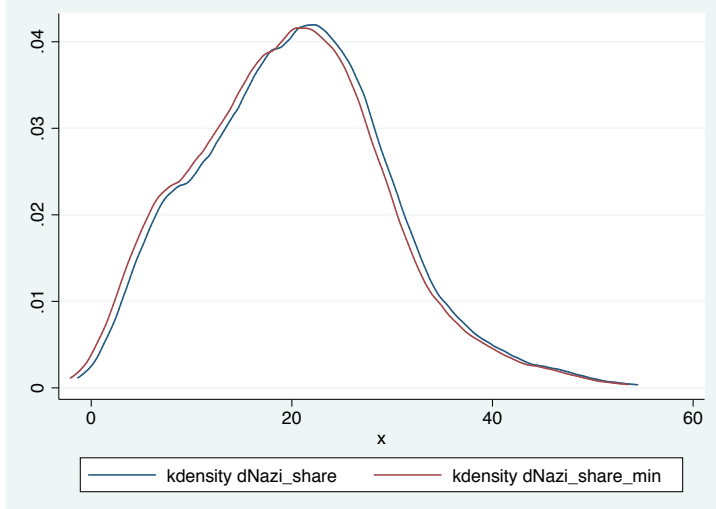

March 1933

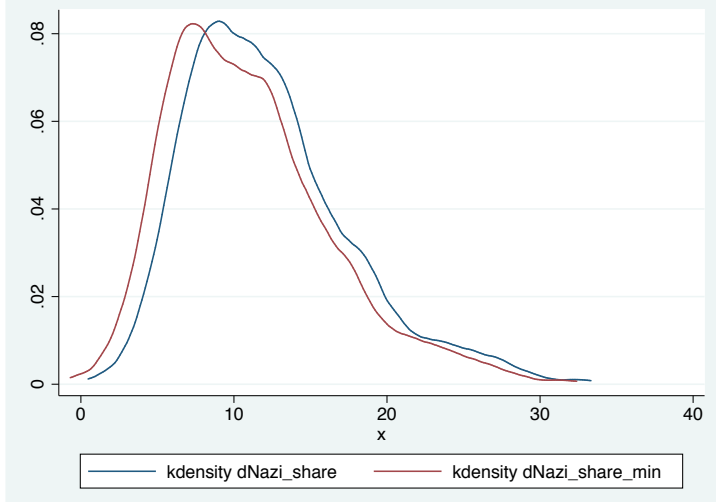


Table A1. Summary Statistics

\begin{tabular}{|c|c|c|c|c|c|}
\hline \multicolumn{6}{|l|}{ Panel A. Voting Variables } \\
\hline Variable & Observations & Mean & Std. Dev. & Min & Max \\
\hline Vote share of SPD, 1924 & 1021 & 0.227 & 0.119 & 0.007 & 0.550 \\
\hline Vote share of KPD, 1924 & 1021 & 0.063 & 0.060 & 0.002 & 0.427 \\
\hline Vote share of DNVP, 1924 & 1021 & 0.207 & 0.156 & 0.006 & 0.848 \\
\hline Vote share of Zentrum, 1924 & 1021 & 0.146 & 0.232 & 0.000 & 0.922 \\
\hline Turnout, 1924 & 1021 & 78.939 & 6.835 & 55.449 & 94.059 \\
\hline Turnout, April 1925 & 1007 & 75.602 & 11.212 & 24.469 & 99.296 \\
\hline Vote share of von Hindenburg, 1925 & 1007 & 53.303 & 19.466 & 5.506 & 96.472 \\
\hline Vote share of Marx, April 1925 & 1007 & 42.293 & 19.394 & 3.354 & 94.064 \\
\hline Vote share of Thälmann, 1925 & 1007 & 4.345 & 4.885 & 0.119 & 36.373 \\
\hline Vote share of NSDAP, 1928 & 1016 & 3.172 & 4.008 & 0.144 & 36.152 \\
\hline Vote share of SPD, 1928 & 1016 & 0.262 & 0.130 & 0.013 & 0.591 \\
\hline Vote share of KPD, 1928 & 1016 & 0.063 & 0.065 & 0.001 & 0.425 \\
\hline Vote share of DNVP, 1928 & 1016 & 0.147 & 0.133 & 0.005 & 0.787 \\
\hline Vote share of Zentrum, 1928 & 1016 & 0.202 & 0.226 & 0.001 & 0.811 \\
\hline Turnout, 1928 & 1016 & 74.676 & 7.980 & 41.552 & 93.548 \\
\hline Approval of anti-Treaty referendum, 1929 & 986 & 12.661 & 12.632 & 0.016 & 64.717 \\
\hline Share of votes "yes" for anti-Treaty referendum, 1929 & 986 & 17.608 & 13.750 & 0.212 & 76.060 \\
\hline Vote share of NSDAP, 1930 & 998 & 19.036 & 8.999 & 1.011 & 58.803 \\
\hline Vote share of SPD, 1930 & 998 & 0.219 & 0.116 & 0.012 & 0.558 \\
\hline Vote share of KPD, 1930 & 998 & 0.085 & 0.069 & 0.002 & 0.444 \\
\hline Vote share of DNVP, 1930 & 998 & 0.070 & 0.074 & 0.003 & 0.492 \\
\hline Vote share of Zentrum, 1930 & 998 & 0.197 & 0.224 & 0.001 & 0.832 \\
\hline Turnout, 1930 & 998 & 80.807 & 6.424 & 56.704 & 94.967 \\
\hline Vote share of von Hindenburg, 1932 & 984 & 50.043 & 15.744 & 8.202 & 88.522 \\
\hline Vote share of Hitler,1932 & 984 & 32.995 & 12.196 & 6.737 & 80.035 \\
\hline Vote share of Thälmann, 1932 & 984 & 9.207 & 6.672 & 0.287 & 42.235 \\
\hline Turnout, April 1932 & 984 & 85.347 & 5.082 & 58.196 & 99.420 \\
\hline Vote share of NSDAP, July 1932 & 993 & 39.449 & 14.721 & 5.865 & 83.004 \\
\hline Vote share of SPD, July 1932 & 993 & 0.186 & 0.101 & 0.009 & 0.495 \\
\hline Vote share of KPD, July 1932 & 993 & 0.101 & 0.067 & 0.004 & 0.395 \\
\hline Vote share of DNVP, July 1932 & 993 & 0.059 & 0.043 & 0.003 & 0.320 \\
\hline Vote share of Zentrum, July 1932 & 993 & 0.201 & 0.225 & 0.001 & 0.864 \\
\hline Turnout, July 1932 & 993 & 83.608 & 6.151 & 54.242 & 95.079 \\
\hline Vote share of NSDAP, November 1932 & 939 & 34.992 & 13.454 & 5.328 & 76.424 \\
\hline Vote share of SPD, November 1932 & 939 & 0.178 & 0.096 & 0.012 & 0.502 \\
\hline Vote share of KPD, November 1932 & 939 & 0.122 & 0.070 & 0.005 & 0.436 \\
\hline Vote share of DNVP, November 1932 & 939 & 0.080 & 0.060 & 0.005 & 0.358 \\
\hline Vote share of Zentrum, November 1932 & 939 & 0.200 & 0.222 & 0.001 & 0.826 \\
\hline Turnout, November 1932 & 939 & 79.770 & 7.051 & 49.193 & 98.269 \\
\hline Vote share of NSDAP, 1933 & 939 & 47.221 & 12.170 & 13.293 & 83.006 \\
\hline Vote share of SPD, 1933 & 939 & 0.156 & 0.091 & 0.007 & 0.464 \\
\hline Vote share of KPD, 1933 & 939 & 0.083 & 0.060 & 0.002 & 0.360 \\
\hline Vote share of Zentrum, 1933 & 939 & 0.175 & 0.191 & 0.000 & 0.777 \\
\hline Turnout, 1933 & 939 & 88.566 & 3.680 & 69.749 & 96.046 \\
\hline Panel B. Signal and Listener Variables & & & & & \\
\hline Variable & Observations & Mean & Std. Dev. & Min & Max \\
\hline Radio signal strength, 1928 & 1023 & 11.159 & 12.748 & -34.748 & 61.195 \\
\hline Radio signal strength, 1929 & 1023 & 11.344 & 12.827 & -34.748 & 61.195 \\
\hline Radio signal strength, 1930 & 1023 & 12.364 & 12.902 & -34.079 & 61.987 \\
\hline Radio listenership (subscriptions per 100), 1931 & 844 & 18.795 & 8.123 & 4.467 & 59.600 \\
\hline Radio signal strength, July 1932 & 1023 & 17.250 & 11.472 & -20.224 & 61.195 \\
\hline Radio listenership (subscriptions per 100), 1932 & 877 & 22.167 & 8.141 & 4.867 & 71.800 \\
\hline Radio signal strength, November 1932 & 1023 & 17.754 & 11.636 & -20.224 & 64.206 \\
\hline Radio signal strength, 1933 & 1023 & 21.801 & 11.127 & -7.268 & 61.195 \\
\hline Radio listenership (subscriptions per 100), 1933 & 878 & 26.311 & 8.653 & 0.443 & 79.337 \\
\hline Radio signal strength, 1935 & 1023 & 25.112 & 10.204 & -1.985 & 69.971 \\
\hline
\end{tabular}


Table A1. Summary statistics (continued)

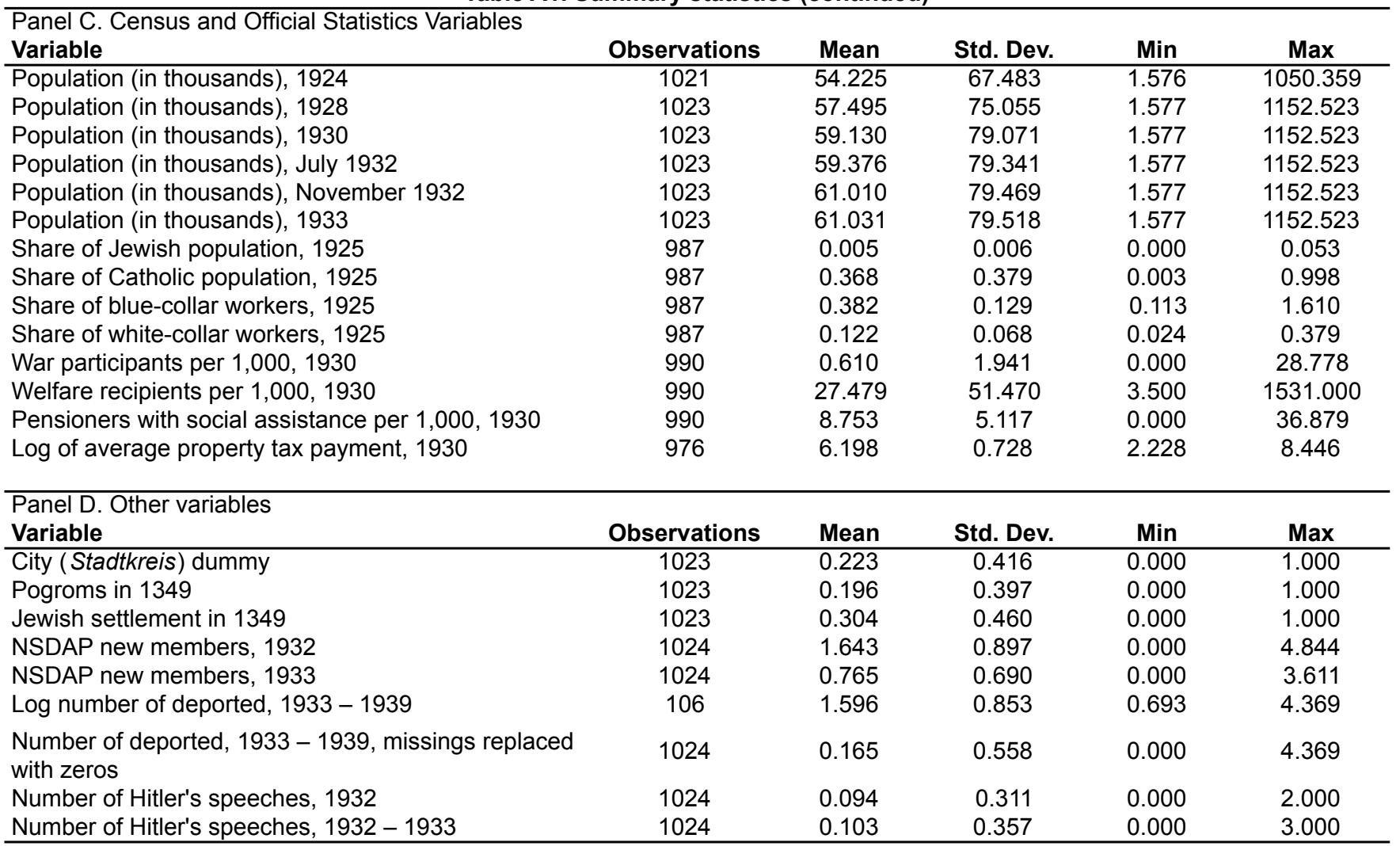


Table A2. Radio Availability and Voting for the Nazis: The Effect of Adding Controls

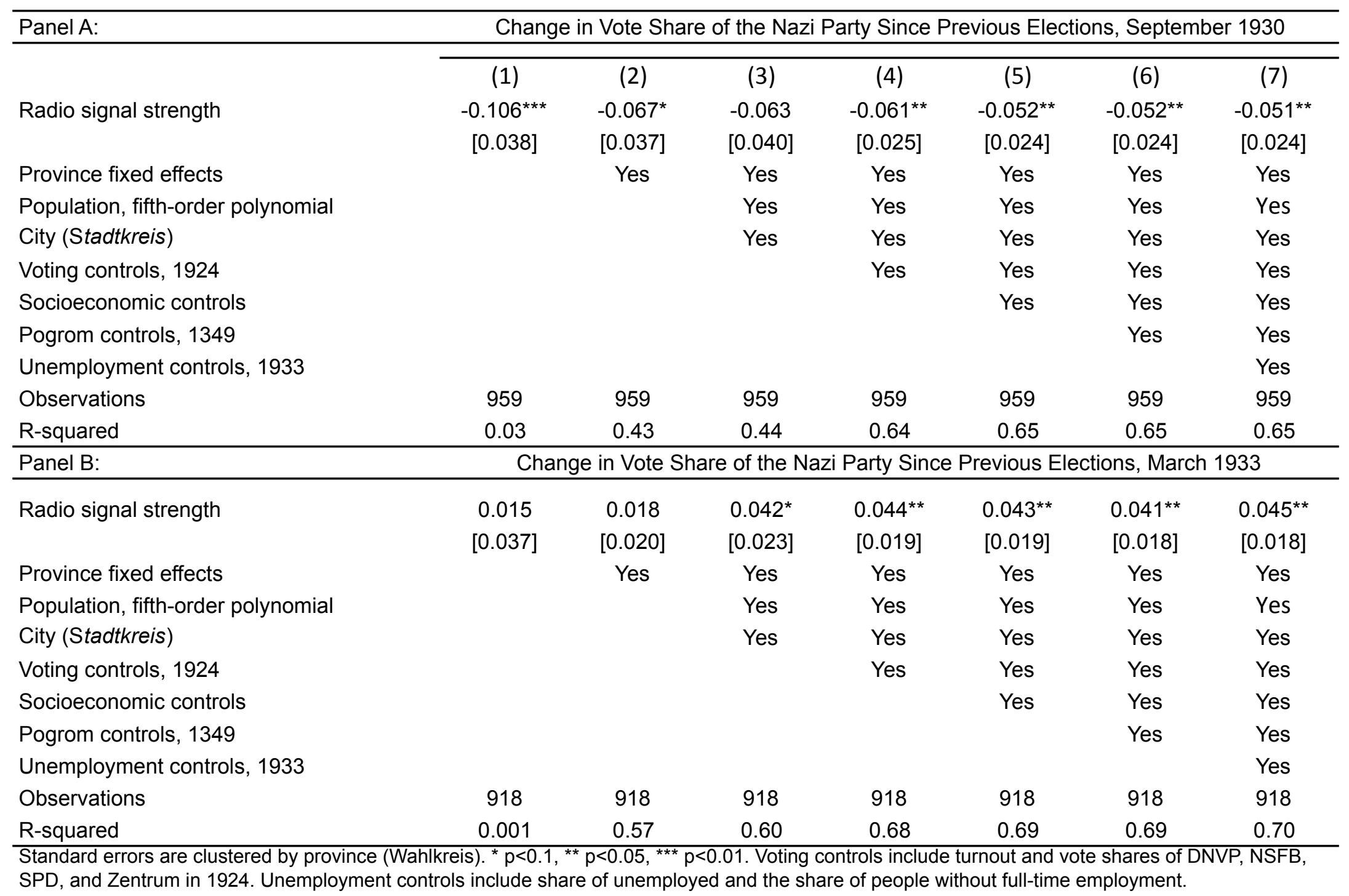


Table A3. Radio Availability and an Increase in Nazi Vote Share. Specification with Binary Explanatory Variable. Panel A Change in Vote Share of the Nazi Party Since Previous Elections (OLS)

\begin{tabular}{|c|c|c|c|c|c|c|c|c|}
\hline & \multicolumn{2}{|c|}{ September 1930} & \multicolumn{2}{|c|}{ July 1932} & \multicolumn{2}{|c|}{ November 1932} & \multicolumn{2}{|c|}{ March 1933} \\
\hline & $(1)$ & $(2)$ & (3) & $(4)$ & (5) & (6) & (7) & $(8)$ \\
\hline \multirow{2}{*}{$\begin{array}{l}\text { Radio signal strength } \\
\text { greater than } 10\end{array}$} & -0.215 & & 0.121 & & $-0.488^{*}$ & & $1.294^{* * *}$ & \\
\hline & {$[0.363]$} & & {$[0.633]$} & & {$[0.280]$} & & {$[0.466]$} & \\
\hline \multirow{2}{*}{$\begin{array}{l}\text { Radio signal strength } \\
\text { greater than } 20\end{array}$} & & $-1.498^{* * *}$ & & 0.096 & & -0.176 & & $0.851^{* *}$ \\
\hline & & {$[0.519]$} & & {$[0.631]$} & & {$[0.244]$} & & {$[0.326]$} \\
\hline All baseline and unemploym€ & Yes & Yes & Yes & Yes & Yes & Yes & Yes & Yes \\
\hline Observations & 959 & 959 & 959 & 959 & 919 & 919 & 918 & 918 \\
\hline R-squared & 0.65 & 0.66 & 0.73 & 0.73 & 0.52 & 0.52 & 0.70 & 0.70 \\
\hline \multirow[t]{2}{*}{ Panel B } & \multicolumn{8}{|c|}{ Change in Vote Share of the Nazi Party Since Previous Elections (Matching) } \\
\hline & \multicolumn{2}{|c|}{ September 1930} & \multicolumn{2}{|c|}{ July 1932} & \multicolumn{2}{|c|}{ November 1932} & \multicolumn{2}{|c|}{ March 1933} \\
\hline \multirow{2}{*}{$\begin{array}{l}\text { Radio signal strength } \\
\text { greater than } 10\end{array}$} & $-0.874^{*}$ & & -0.243 & & -0.292 & & $1.050^{* *}$ & \\
\hline & {$[0.495]$} & & {$[0.904]$} & & {$[0.255]$} & & {$[0.508]$} & \\
\hline \multirow{2}{*}{$\begin{array}{l}\text { Radio signal strength } \\
\text { greater than } 20\end{array}$} & & $-1.555^{\star * *}$ & & -0.733 & & 0.145 & & 0.112 \\
\hline & & {$[0.513]$} & & {$[0.617]$} & & {$[0.208]$} & & {$[0.311]$} \\
\hline Observations & 959 & 959 & 959 & 959 & 919 & 919 & 918 & 918 \\
\hline
\end{tabular}

Note: Controls include voter turnout and vote shares of DNVP, NSFB, SPD, and Zentrum in 1924; fifth-order polynomial of population, share of unemployed, share of people without full-time employment, and province fixed effects. Number of observations changes between July and November of 1932 because of redistricting. Panel B presents ther results of the nearest neighbor matching estimation of the average treatment effect on the treated. Matching on all the control variables. Matching on all dummy variables is exact. Standard errors in Panel A are clustered by province (Wahlkreis) in parentheses. Heteroskedasticityconsistent standard errors using 5 matches in Panel B. ${ }^{*} p<0.1,{ }^{* *} p<0.05,{ }^{* *} p<0.01$. 
Table A4. Radio Availability and Voting for the Nazis: Cross-Sectional Estimates

Radio signal strength

Share of Jewish population, 1925

Share of Catholic population, 1925

March $1928 \quad$ September $1930 \quad$ July 1932

(2)

(3)

(4)

(5)

(6)

(7)

(8)

March 1933

\begin{tabular}{|c|c|c|c|c|c|c|c|c|c|}
\hline-0.014 & -0.015 & $-0.069^{* *}$ & $-0.068^{* *}$ & -0.059 & -0.055 & $-0.069^{*}$ & -0.062 & -0.037 & -0.026 \\
\hline [0.014] & {$[0.015]$} & {$[0.026]$} & [0.026] & [0.039] & [0.038] & {$[0.039]$} & [0.039] & [0.036] & {$[0.034]$} \\
\hline-39.345 & -40.156 & 3.988 & 2.918 & 77.763 & $80.527^{*}$ & $149.414^{* * *}$ & $152.292^{* * *}$ & $145.882^{* * *}$ & $151.417^{* * *}$ \\
\hline [34.535] & [35.393] & [63.783] & [63.082] & [47.848] & [47.518] & [38.308] & [41.509] & [47.139] & [41.060] \\
\hline$-4.659^{* * *}$ & $-4.636^{* * *}$ & $-9.103^{* * *}$ & $-9.070^{* * *}$ & $-33.518^{* * *}$ & $-33.576^{\star * *}$ & $-28.876^{\star * *}$ & $-28.968^{* * *}$ & $-26.516^{* * *}$ & $-26.638^{* * *}$ \\
\hline [1.304] & [1.293] & [3.126] & [3.155] & [2.951] & [3.001] & [3.012] & [2.996] & [3.449] & [3.511] \\
\hline-0.790 & -0.954 & $-6.815^{\star * *}$ & $-6.748^{* *}$ & $-13.361^{* * *}$ & $-11.843^{* * *}$ & $-11.058^{* * *}$ & $-9.053^{* *}$ & $-15.270^{* * *}$ & $-12.168^{* *}$ \\
\hline [0.884] & [1.117] & [2.457] & [2.606] & [4.062] & [4.090] & [3.994] & [4.305] & [4.991] & [5.059] \\
\hline $3.761^{* *}$ & $4.022^{* *}$ & $9.121^{*}$ & $9.789^{* *}$ & -5.620 & -5.356 & $-10.364^{*}$ & -8.427 & $-18.852^{* * *}$ & $-15.595^{\star *}$ \\
\hline [1.767] & [1.890] & [4.564] & [4.610] & [6.169] & [6.858] & [5.921] & [6.235] & [6.702] & [6.721] \\
\hline 0.038 & -0.001 & 0.168 & 0.248 & $-1.554^{*}$ & -1.032 & $-2.108^{* *}$ & -1.287 & $-2.253^{* * *}$ & -0.984 \\
\hline [0.450] & [0.411] & [0.751] & [0.770] & [0.882] & [0.925] & [0.925] & [0.878] & [0.822] & [0.778] \\
\hline $0.513^{*}$ & $0.519^{*}$ & 0.684 & 0.688 & -0.109 & -0.149 & 0.176 & 0.097 & 0.360 & 0.254 \\
\hline [0.299] & {$[0.306]$} & [0.484] & [0.484] & {$[0.787]$} & [0.766] & [0.760] & [0.742] & [0.872] & {$[0.834]$} \\
\hline$-0.345^{*}$ & $-0.341^{*}$ & -0.042 & -0.009 & 0.068 & 0.146 & -0.011 & 0.108 & -1.063 & -0.879 \\
\hline [0.193] & [0.195] & [0.486] & [0.494] & [0.659] & [0.664] & [0.636] & [0.654] & [0.749] & {$[0.747]$} \\
\hline 0.019 & 0.018 & 0.048 & 0.049 & -0.017 & -0.001 & 0.057 & 0.079 & -0.021 & 0.014 \\
\hline [0.035] & {$[0.034]$} & [0.074] & [0.073] & [0.060] & [0.062] & [0.046] & [0.049] & [0.070] & {$[0.072]$} \\
\hline 0.001 & 0.001 & 0.000 & 0.000 & -0.001 & -0.001 & -0.002 & $-0.002^{* *}$ & 0.001 & 0.000 \\
\hline [0.001] & [0.001] & [0.001] & [0.001] & [0.001] & [0.001] & [0.001] & [0.001] & [0.001] & [0.001] \\
\hline 0.012 & 0.014 & -0.018 & -0.015 & -0.009 & -0.015 & 0.001 & 0.002 & -0.052 & -0.049 \\
\hline$[0.024]$ & {$[0.023]$} & [0.050] & {$[0.050]$} & {$[0.057]$} & [0.054] & [0.048] & [0.044] & [0.049] & {$[0.042]$} \\
\hline 0.389 & $0.396^{*}$ & 0.497 & 0.489 & 0.119 & 0.044 & -0.416 & -0.518 & -0.131 & -0.290 \\
\hline [0.233] & [0.233] & [0.314] & [0.323] & [0.345] & [0.354] & [0.360] & [0.368] & [0.460] & [0.454] \\
\hline
\end{tabular}

Population, fifth-order polynomial

Voting controls, 1924

Province fixed effects

Unemployment controls, 1933

Observations

Yes

Yes Yes

Yes Yes

No Yes

$959 \quad 959$

Yes

Yes

Yes

0.59

0.59

No

Yes

Yes

Yes

Yes

960

0.67

0.67

Yes

Yes

Yes

Yes

Yes

Yes

Yes

$959 \quad 959$

959
0.88

Yes

Yes

Yes

No

919

0.85

Yes

Yes

Yes

Yes

919

0.85

Yes

Yes

Note: Standard errors clustered by province (Wahlkreis) in parentheses. ${ }^{*} p<0.1,{ }^{* *} p<0.05$ 0.88

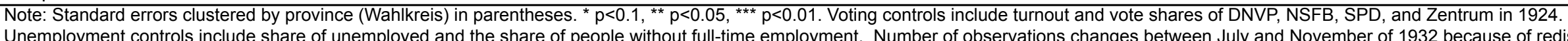

Yes Yes

No Yes


Table A5. Radio Availability and Turnout.

\begin{tabular}{|c|c|c|c|c|c|c|c|c|}
\hline & \multicolumn{8}{|c|}{ Change in Turnout Since Previous Elections } \\
\hline & \multicolumn{2}{|c|}{ September 1930} & \multicolumn{2}{|c|}{ July 1932} & \multicolumn{2}{|c|}{ November 1932} & \multicolumn{2}{|c|}{ March 1933} \\
\hline & (1) & (2) & (3) & $(4)$ & (5) & (6) & $(7)$ & $(8)$ \\
\hline \multirow[t]{2}{*}{ Radio signal strength } & -0.008 & -0.009 & $-0.031^{*}$ & $-0.032^{*}$ & $0.012^{*}$ & $0.013^{*}$ & $0.029^{* *}$ & $0.029^{* *}$ \\
\hline & {$[0.018]$} & {$[0.017]$} & {$[0.017]$} & {$[0.016]$} & {$[0.007]$} & {$[0.007]$} & {$[0.013]$} & {$[0.013]$} \\
\hline \multirow[t]{2}{*}{ Share of Jewish population, 1925} & 2.204 & 0.398 & $47.865^{\star *}$ & $50.398^{* *}$ & 22.652 & 25.292 & $-68.187^{* *}$ & $-72.156^{* *}$ \\
\hline & [26.093] & [25.866] & [22.325] & [22.610] & [25.786] & [26.248] & [32.531] & [32.293] \\
\hline \multirow[t]{2}{*}{ Share of Catholic population, 1925} & -0.350 & -0.301 & -2.853 & -2.928 & -0.669 & -0.729 & 0.364 & 0.450 \\
\hline & {$[1.290]$} & {$[1.297]$} & {$[1.970]$} & {$[1.960]$} & {$[0.805]$} & {$[0.851]$} & {$[1.583]$} & {$[1.568]$} \\
\hline \multirow[t]{2}{*}{ Share of blue-collar workers, 1925} & 0.563 & 0.057 & -0.552 & -0.399 & $-2.688^{* * *}$ & $-2.135^{\star *}$ & $-2.609^{*}$ & $-3.231^{* *}$ \\
\hline & [1.582] & [1.520] & [1.261] & [1.348] & [0.789] & [0.919] & [1.322] & [1.505] \\
\hline \multirow[t]{2}{*}{ Share of white-collar workers, 1925} & $18.607^{* \star *}$ & $19.055^{\star * *}$ & $-10.036^{* * *}$ & $-11.291^{* * *}$ & 0.168 & -0.780 & 1.583 & 3.388 \\
\hline & {$[3.793]$} & {$[3.797]$} & {$[2.972]$} & {$[3.202]$} & {$[2.418]$} & {$[2.515]$} & {$[2.351]$} & {$[2.733]$} \\
\hline \multirow[t]{2}{*}{ City (Stadtkreis) } & -0.365 & -0.506 & $-1.841^{* * *}$ & $-1.897^{\star * *}$ & 0.162 & 0.243 & 0.071 & 0.050 \\
\hline & [0.597] & {$[0.600]$} & [0.483] & [0.516] & [0.459] & [0.485] & [0.467] & [0.468] \\
\hline \multirow[t]{2}{*}{ Pogroms in 1349} & $-1.033^{* *}$ & $-1.019^{* *}$ & $0.715^{\star}$ & $0.699^{*}$ & -0.049 & -0.070 & 0.458 & 0.482 \\
\hline & [0.413] & [0.410] & {$[0.351]$} & [0.355] & [0.250] & [0.246] & [0.333] & {$[0.320]$} \\
\hline \multirow[t]{2}{*}{ Jewish settlement in 1349} & 0.427 & 0.421 & 0.026 & -0.018 & 0.081 & 0.077 & $-0.529 * *$ & $-0.505^{* *}$ \\
\hline & {$[0.421]$} & {$[0.421]$} & {$[0.317]$} & [0.321] & [0.226] & [0.235] & [0.194] & [0.193] \\
\hline \multirow[t]{2}{*}{ War participants per 1,000} & $0.149^{* * *}$ & $0.144^{* * *}$ & -0.014 & -0.013 & 0.040 & 0.045 & -0.072 & -0.076 \\
\hline & {$[0.047]$} & {$[0.048]$} & {$[0.035]$} & [0.035] & {$[0.043]$} & {$[0.042]$} & {$[0.046]$} & [0.045] \\
\hline \multirow[t]{2}{*}{ Welfare recipients per 1,000} & -0.001 & -0.001 & -0.001 & -0.002 & $-0.001^{* * *}$ & $-0.002^{* * *}$ & 0.001 & 0.001 \\
\hline & {$[0.001]$} & {$[0.001]$} & [0.002] & [0.002] & [0.000] & [0.001] & [0.001] & [0.001] \\
\hline \multirow{2}{*}{$\begin{array}{l}\text { Pensioners with social assistance } \\
\text { per } 1,000\end{array}$} & $-0.078^{* *}$ & $-0.074^{* *}$ & $0.080^{* *}$ & $0.073^{* *}$ & 0.003 & -0.004 & $-0.087^{* * *}$ & $-0.076^{* * *}$ \\
\hline & {$[0.037]$} & {$[0.036]$} & {$[0.033]$} & {$[0.032]$} & {$[0.018]$} & {$[0.019]$} & {$[0.020]$} & {$[0.023]$} \\
\hline \multirow[t]{2}{*}{ Log of average property tax payment } & 0.378 & 0.399 & -0.480 & $-0.478^{*}$ & -0.020 & -0.040 & -0.233 & -0.213 \\
\hline & [0.273] & [0.272] & [0.289] & [0.282] & [0.183] & [0.182] & {$[0.175]$} & [0.169] \\
\hline Population, fifth-order polynomial & Yes & Yes & Yes & Yes & Yes & Yes & Yes & Yes \\
\hline Voting controls, 1924 & Yes & Yes & Yes & Yes & Yes & Yes & Yes & Yes \\
\hline Province fixed effects & Yes & Yes & Yes & Yes & Yes & Yes & Yes & Yes \\
\hline Unemployment controls, 1933 & & Yes & & Yes & & Yes & & Yes \\
\hline Observations & 959 & 959 & 959 & 959 & 919 & 919 & 918 & 918 \\
\hline R-squared & 0.59 & 0.60 & 0.55 & 0.55 & 0.32 & 0.33 & 0.67 & 0.67 \\
\hline
\end{tabular}


Table A6. Radio Availability, Hitler's Speeches, and Voting for the Nazis in March 1933

\begin{tabular}{|c|c|c|c|c|}
\hline \multirow[b]{2}{*}{ Signal strength $x$ Number of speeches in 1932} & \multicolumn{4}{|c|}{$\begin{array}{c}\text { Change in Vote Share of the Nazi Party Since Previous } \\
\text { Elections }\end{array}$} \\
\hline & 0.021 & 0.081 & & \\
\hline & {$[0.372]$} & {$[0.356]$} & & \\
\hline \multirow[t]{2}{*}{ Number of speeches in 1932} & -0.002 & -0.004 & & \\
\hline & {$[0.012]$} & [0.011] & & \\
\hline \multirow[t]{2}{*}{ Signal strength x Dummy for a speech in 1932} & & & -0.285 & -0.183 \\
\hline & & & [0.439] & [0.413] \\
\hline \multirow[t]{2}{*}{ Dummy for a speech in 1932} & & & -0.008 & -0.014 \\
\hline & & & {$[0.025]$} & {$[0.023]$} \\
\hline \multirow[t]{2}{*}{ Radio signal strength } & $0.042^{* *}$ & $0.047^{* *}$ & $0.042^{* *}$ & $0.047^{* *}$ \\
\hline & {$[0.018]$} & {$[0.018]$} & {$[0.019]$} & {$[0.018]$} \\
\hline \multirow[t]{2}{*}{ Share of Jewish population, 1925} & 3.126 & 5.110 & 2.543 & 4.395 \\
\hline & {$[45.730]$} & {$[41.717]$} & {$[45.047]$} & [41.003] \\
\hline \multirow[t]{2}{*}{ Share of Catholic population, 1925} & 2.391 & 2.353 & 2.334 & 2.298 \\
\hline & [2.214] & [2.279] & [2.242] & [2.314] \\
\hline \multirow[t]{2}{*}{ Share of blue-collar workers, 1925} & $-4.361^{*}$ & -3.228 & $-4.534^{*}$ & -3.413 \\
\hline & {$[2.310]$} & [2.296] & {$[2.335]$} & [2.333] \\
\hline \multirow[t]{2}{*}{ Share of white-collar workers, 1925} & $-8.444^{* *}$ & $-7.263^{* *}$ & $-7.598^{\star *}$ & $-6.287^{*}$ \\
\hline & {$[3.441]$} & [3.205] & {$[3.251]$} & [3.091] \\
\hline \multirow[t]{2}{*}{ City (Stadtkreis) } & -0.155 & 0.305 & -0.090 & 0.387 \\
\hline & {$[0.522]$} & {$[0.538]$} & {$[0.530]$} & {$[0.545]$} \\
\hline \multirow[t]{2}{*}{ Pogroms in 1349} & 0.240 & 0.204 & 0.234 & 0.197 \\
\hline & {$[0.327]$} & {$[0.317]$} & {$[0.328]$} & {$[0.318]$} \\
\hline \multirow[t]{2}{*}{ Jewish settlement in 1349} & $-1.023^{* * *}$ & $-0.956^{* * *}$ & $-1.020^{* * *}$ & $-0.953^{* * *}$ \\
\hline & {$[0.304]$} & {$[0.281]$} & {$[0.305]$} & {$[0.282]$} \\
\hline \multirow[t]{2}{*}{ War participants per 1,000} & -0.066 & -0.054 & -0.066 & -0.052 \\
\hline & {$[0.051]$} & [0.051] & {$[0.052]$} & {$[0.051]$} \\
\hline \multirow[t]{2}{*}{ Welfare recipients per 1,000} & $0.003^{* *}$ & $0.003^{*}$ & $0.003^{* *}$ & $0.003^{* *}$ \\
\hline & [0.001] & [0.001] & {$[0.001]$} & {$[0.001]$} \\
\hline \multirow[t]{2}{*}{ Pensioners with social assistance per 1,000} & $-0.053^{*}$ & $-0.051^{*}$ & $-0.054^{*}$ & $-0.052^{*}$ \\
\hline & {$[0.026]$} & {$[0.028]$} & {$[0.027]$} & {$[0.029]$} \\
\hline \multirow[t]{2}{*}{ Log of average property tax payment } & 0.253 & 0.195 & 0.249 & 0.189 \\
\hline & {$[0.263]$} & {$[0.253]$} & {$[0.263]$} & {$[0.252]$} \\
\hline Province fixed effects & Yes & Yes & Yes & Yes \\
\hline Population, fifth-order polynomial & Yes & Yes & Yes & Yes \\
\hline Voting controls, 1924 & Yes & Yes & Yes & Yes \\
\hline Unemployment controls, 1933 & No & Yes & No & Yes \\
\hline Observations & 918 & 918 & 918 & 918 \\
\hline R-squared & 0.69 & 0.29 & 0.69 & 0.70 \\
\hline
\end{tabular}


Table A7. Radio Availability and Anti-Semitism, the Role of Predispositions

\begin{tabular}{|c|c|c|c|c|c|c|}
\hline \multirow[t]{2}{*}{ Sample: } & \multicolumn{3}{|c|}{ All Cities } & \multicolumn{3}{|c|}{ Only Cities with Jewish Settlements in 1349} \\
\hline & $\begin{array}{l}\text { Letters to } \\
\text { Der Stürmer }\end{array}$ & $\begin{array}{l}\text { Log(deportations } \\
\text { before 1942) }\end{array}$ & $\begin{array}{c}\text { Attacks on } \\
\text { synagogues }\end{array}$ & $\begin{array}{l}\text { Letters to } \\
\text { Der Stürmer }\end{array}$ & $\begin{array}{l}\text { Log(deportation } \\
\text { s before 1942) }\end{array}$ & $\begin{array}{c}\text { Attacks on } \\
\text { synagogues }\end{array}$ \\
\hline & (1) & $(2)$ & (3) & $(4)$ & $(5)$ & (6) \\
\hline \multirow[t]{2}{*}{ Vote for DVFP in $1924^{\star}$ Radio signal strength } & $0.098^{* * *}$ & 0.100 & 0.007 & $0.067^{*}$ & 0.007 & $0.028^{* *}$ \\
\hline & {$[0.023]$} & {$[0.087]$} & {$[0.013]$} & {$[0.039]$} & {$[0.107]$} & {$[0.012]$} \\
\hline \multirow[t]{2}{*}{ Vote for DVFP in 1924} & 0.464 & 2.773 & 0.840 & 0.613 & 5.779 & -0.135 \\
\hline & {$[1.058]$} & {$[2.504]$} & {$[0.526]$} & {$[1.965]$} & {$[3.608]$} & {$[0.572]$} \\
\hline All baseline and unemployment controls & Yes & Yes & Yes & Yes & Yes & Yes \\
\hline Province fixed effects & Yes & Yes & Yes & Yes & Yes & Yes \\
\hline Observations & 1217 & 1157 & 989 & 308 & 286 & 265 \\
\hline R-squared & 0.41 & 0.34 & 0.13 & 0.54 & 0.56 & 0.23 \\
\hline \multirow[t]{2}{*}{ Vote for NSDAP in $1928^{\star}$ Radio signal strength } & 0.069 & -0.087 & -0.020 & 0.051 & -0.198 & 0.033 \\
\hline & {$[0.107]$} & {$[0.180]$} & {$[0.040]$} & {$[0.113]$} & {$[0.178]$} & {$[0.042]$} \\
\hline \multirow[t]{2}{*}{ Vote for NSDAP in 1928} & -0.064 & 0.439 & -0.176 & 2.149 & $5.841^{*}$ & 0.066 \\
\hline & {$[1.775]$} & {$[3.612]$} & {$[1.121]$} & {$[3.014]$} & {$[3.320]$} & {$[1.492]$} \\
\hline All baseline and unemployment controls & Yes & Yes & Yes & Yes & Yes & Yes \\
\hline Province fixed effects & Yes & Yes & Yes & Yes & Yes & Yes \\
\hline Observations & 1216 & 1156 & 988 & 308 & 286 & 265 \\
\hline R-squared & 0.40 & 0.34 & 0.12 & 0.54 & 0.56 & 0.23 \\
\hline
\end{tabular}

